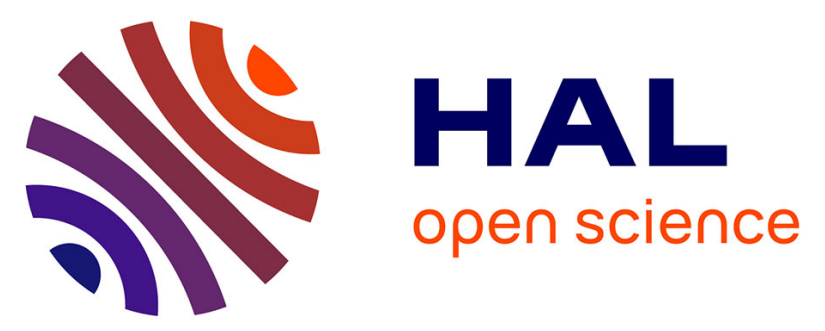

\title{
Variscan Sb-Au mineralization in Central Brittany (France): A new metallogenic model derived from the Le Semnon district
}

Anthony Pochon, Eric Gloaguen, Yannick Branquet, Marc Poujol, Gilles Ruffet, Marie-Christine Boiron, Philippe Boulvais, Charles Gumiaux, Florence Cagnard, Fanny Gouazou

\section{To cite this version:}

Anthony Pochon, Eric Gloaguen, Yannick Branquet, Marc Poujol, Gilles Ruffet, et al.. Variscan Sb-Au mineralization in Central Brittany (France): A new metallogenic model derived from the Le Semnon district. Ore Geology Reviews, 2018, 97, pp.109 - 142. 10.1016/j.oregeorev.2018.04.016 . insu-01796918

\section{HAL Id: insu-01796918 https://hal-insu.archives-ouvertes.fr/insu-01796918}

Submitted on 17 Feb 2021

HAL is a multi-disciplinary open access archive for the deposit and dissemination of scientific research documents, whether they are published or not. The documents may come from teaching and research institutions in France or abroad, or from public or private research centers.
L'archive ouverte pluridisciplinaire HAL, est destinée au dépôt et à la diffusion de documents scientifiques de niveau recherche, publiés ou non, émanant des établissements d'enseignement et de recherche français ou étrangers, des laboratoires publics ou privés. 


\title{
Variscan Sb-Au mineralization in Central Brittany (France): A new metallogenic model derived from the Le Semnon district
}

\author{
Anthony Pochon ${ }^{\mathrm{a},}$, Eric Gloaguen ${ }^{\mathrm{b}, \mathrm{c}}$, Yannick Branquet ${ }^{\mathrm{a}, \mathrm{b}}$, Marc Poujol ${ }^{\mathrm{a}}$, Gilles Ruffet ${ }^{\mathrm{a}, \mathrm{e}}$, Marie- \\ Christine Boiron $^{\mathrm{d}}$, Philippe Boulvais ${ }^{\mathrm{a}}$, Charles Gumiaux ${ }^{\mathrm{b}}$, Florence Cagnard ${ }^{\mathrm{c}}$, Fanny Gouazou ${ }^{\mathrm{d}}$, \\ Denis Gapais $^{\mathrm{a}}$ \\ ${ }^{a}$ Géosciences Rennes, UMR CNRS 6118, Université de Rennes 1, OSUR, Campus de Beaulieu, 35042 Rennes Cedex, France \\ ${ }^{\mathrm{b}}$ Institut des Sciences de la Terre d'Orléans, UMR 7327, Université d'Orléans, Campus Géosciences, 1A rue de la Férollerie, 45071 Orléans Cedex 2 , France ${ }^{\mathrm{c}}$ \\ Bureau de Recherche Géologique et Minière (BRGM), UMR 7327, 3 Avenue Claude-Guillemin, B.P. 36009, 45060 Orléans Cedex 02, France \\ ${ }^{\mathrm{d}}$ GeoRessources, CNRS, Université de Lorraine, CREGU, Faculté des Sciences et Technologies, Campus des Aiguillettes, B.P. 70239 , F-54506 Vandœuvre-lès-Nancy \\ Cedex, France \\ ${ }^{\mathrm{e}}$ CNRS (CNRS/INSU), UMR 6118, Géosciences Rennes, F-35042 Rennes Cedex, France
}

\section{ARTICLE INFO}

\section{Keywords:}

Shallow Sb-Au mineralization

Early Carboniferous hydrothermal event

Spatio-temporal link with mafic rocks

Le Semnon deposit

Armorican Massif

\begin{abstract}
Numerous Sb-Au deposits are known in the European Variscan belt and are often associated with the late Variscan hydrothermal events linked to postorogenic extension and strike-slip faults, through the whole belt. The central part of the Armorican Massif (Central Brittany) hosts several Sb-Au deposits, such as the Le Semnon deposit. However, little is known about its formation, its structural control or hydrothermal history. In order to provide new constraints on the $\mathrm{Sb}-\mathrm{Au}$ mineralization framework of the Variscan Armorican Massif, structural, geochronological and chemical analyses have been performed on the Le Semnon Sb-Au deposit. First, we highlight that Sb-Au mineralization consists of fault-fill and flat extensional vein systems resulting from small-scale fault-valve mechanism controlled by fluid overpressure at shallow depth. Indeed, this deposit is char-acterized by the presence of dolerite dykes which acted as the plumbing system for fluids within impermeable slates. The low permeability of the slates permitted the establishment of local supralithostatic fluid pressure in a predominantly hydrostatic regime. Coupled with new (micro-) textural evidences, a reappraisal of the para-genetic evolution and new physico-chemical data, ${ }^{40} \mathrm{Ar} /{ }^{39} \mathrm{Ar}$ and $\mathrm{U}-\mathrm{Pb}$ analyses show that the Le Semnon Sb-Au mineralization was emplaced around $360 \mathrm{Ma}$ and therefore indicates an early hydrothermal event in the Variscan history of the Armorican Massif. Moreover, absolute dating of mafic magmatism coupled with hy-drothermal alteration associated with the deposition of Sb-Au mineralization strongly suggest that the empla-cement of the $\mathrm{Sb}-\mathrm{Au}$ mineralization was coeval with the emplacement of the host rock doleritic dyke. Furthermore, the high temperature recorded in fluid inclusions and the paragenetic evolution suggests an ele-vated thermal anomaly in Central Brittany. Thus, we propose that the emplacement of the widespread mafic magmatism at ca. 360 Ma played a major role in the mobilization of fluid flows and the redistribution of metals in the Armorican crust.
\end{abstract}

\section{Introduction}

Antimony deposits are frequently associated with other metals such as gold, arsenic or mercury. Sb-Au mineralization mainly forms at shallow depths and are classified in the orogenic gold type deposit (e.g. Groves et al., 1998, 2003; Bierlein and Crowe, 2000; Goldfarb et al., 2001, 2005; Goldfarb and Groves, 2015). Although most orogenic $\mathrm{Au} \pm \mathrm{Sb}$ deposits are mainly Archean and Proterozoic in age, some are known in Phanerozoic belts, such as the European Variscan belt (Romer and Kroner, 2018). Indeed, Sb-Au deposits are widespread in the Iberian Massif in Spain and Portugal (e.g. Gumiel and Arribas, 1987; Couto et al., 1990; Neiva et al., 2008), in the French Massif Central (FMC) and Armorican Massif in France (e.g. Périchaud, 1980; Boiron et al., 1990; Bril and Beaufort, 1989; Chauris and Marcoux, 1994; Bouchot et al., 2005), in the SaxoThuringian zone in Germany (Dill, 1985; Wagner and Cook, 2000), in the Bohemian Massif (e.g. Němec and Zachariáš, 2017) and in the Slovakian Western Carpathians (e.g. Chovan et al., 1995). Variscan Sb-Au hydrothermal deposits share many 
features such as (1) spatial relationships with regional-scale faults and shear zones (e.g. Bellot et al., 2003), (2) localization of Sb-Au quartz veins within anticlinal hinges, or (3) relation with late-Variscan tec-tonic processes (e.g. post-thickening collapse, Bouchot et al., 2005). Sb-Au deposits from the FMC are thus considered to be formed during a short-time and large-scale hydrothermal event around $300 \mathrm{Ma}$ resulting from thermal events related to the post-thickening collapse of the Variscan orogen (Costa and Rey, 1995; Bouchot et al., 2005). During this period, Sb-Au deposits results from the exhumation of lower con-tinental crust and the mixing between deep metamorphic fluids and cold meteoric fluids (Boiron et al., 2003).

Although the Armorican Massif contains the largest part of the $\mathrm{Sb}$ resources in France (Gloaguen et al., 2016a), Sb-Au deposits are not very well documented compared to those from the FMC. In particular in Central Brittany, the hydrothermal history of $\mathrm{Sb}-\mathrm{Au}$ mineralization re-mains unconstrained. It is commonly assumed that regional-scale shear zones control the localization of the deposits. Chauris and Marcoux (1994) suggested that the $\mathrm{Sb}$ could be sourced from various felsic magmatic rocks emplaced during the Cambrian-Carboniferous period, and deposited within Late Variscan shear zones. However, in Central Britany, a significant part of the $\mathrm{Sb}-\mathrm{Au}$ deposits, including the Le Semnon Sb-Au deposit, is located away from main shear zones (Fig. 1). In addition, Pochon et al. (2016a) highlighted the strong spatial re-lationship between $\mathrm{Sb}-\mathrm{Au}$ mineralization and high density and mag-netic zones, which have been interpreted as mafic/ultramafic bodies present at depth. In this paper, we focus on the Le Semnon Sb-Au deposit, which represents up-to-date the largest potential in $\mathrm{Sb}$ resources in the Armorican Massif (Gloaguen et al., 2016b). We present evidence for a structural control of the mineralization together with geochemical data on mafic rocks associated with the mineralization, geochronolo-gical, isotopic and fluid inclusions data that help constraining the hy-drothermal event responsible for its emplacement. We reveal that the
Sb-Au mineralization formed from shallow fluid flow associated with mafic magmatism. Mineralization was early in the Variscan history of the Armorican Massif (near $360 \mathrm{Ma}$ ), significantly older than the as-sumed Late Variscan age for other Sb-Au deposits from the West-Eur-opean Variscan belt.

\section{Geological background}

\subsection{Central Brittany}

Central Brittany, in the central part of the Armorican Massif, be-longs to the external domain of the West-European Variscan belt, which resulted from the continental collision between the Gondwana and Laurussia plates and the Armorica microplate (Ballèvre et al., 2009, 2014). This collision began during the late Devonian, highlighted by the record of continental subduction at $\mathrm{c}$. $360 \mathrm{Ma}$ (Bosse et al., 2000, 2005; Paquette et al., 2017), and ended during the late Carboniferous around $300 \mathrm{Ma}$ (Matte, 1986; Gumiaux et al., 2004b; Ballèvre et al., 2014). This domain is bounded by two dextral crustal-scale shear zones (Fig. 1), the North Armorican Shear Zone (NASZ) and the northern branch of the South Armorican Shear Zone (SASZ). Another shear zone, the Mon-tagnes Noires Shear Zone (MNSZ), separates two distinct subdomains with contrasted structural styles and magmatic history, the Western and Eastern Central Brittany (Gumiaux et al., 2004b). Eastern Central Brittany is characterized by a continuous Carboniferous deformation that affected the Late Neoproterozoic to upper Paleozoic sediments, compatible with the $\mathrm{N} 125^{\circ} \mathrm{E}$-trending dextral simple shear strike slip of the entire Central Brittany (Gumiaux et al., 2004a, 2004b). Deforma-tion is characterized by upright folds with E-W striking and horizontal axes and wavelengthcontrolled by the competent and thick unit of the lower Ordovician Armorican sandstone. Folds are associated with a sub-vertical axial-plane cleavage bearing a sub-horizontal lineation parallel

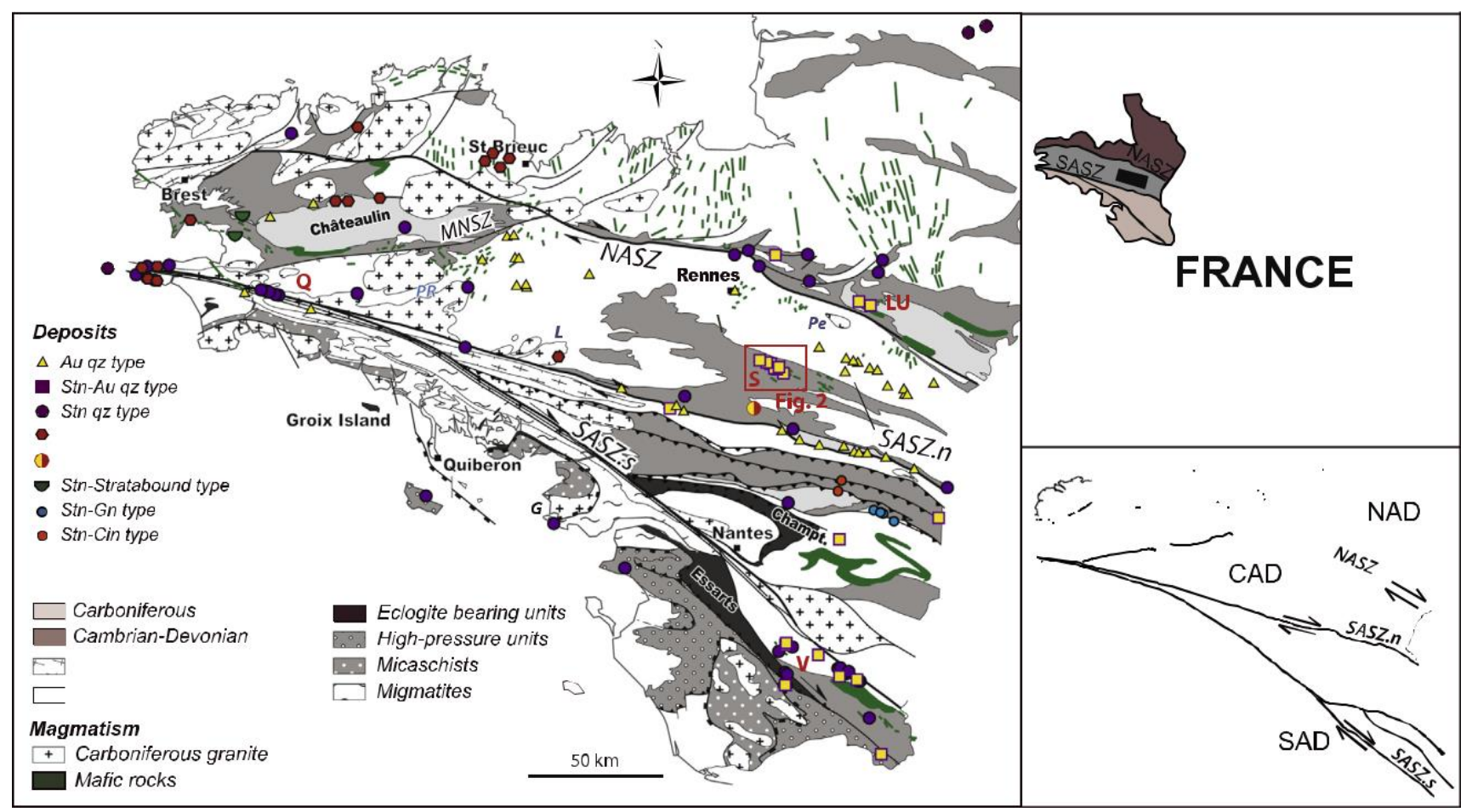

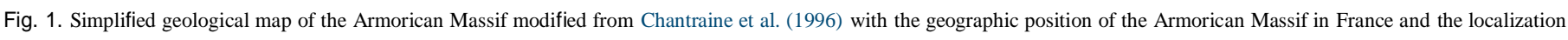

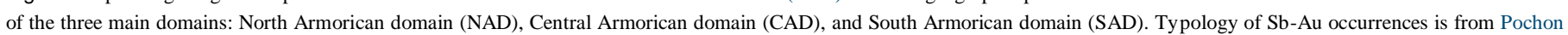

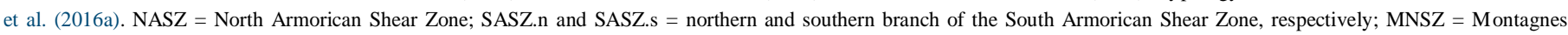

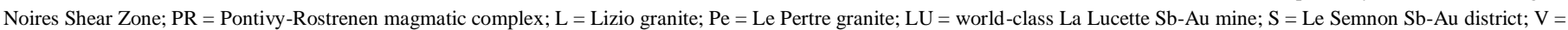
Vendée Sb-(Au) district; Q = Quimper-Cap Sizun Sb district; Stb = stibnite; Gn = galena; Cin = cinnabar. 
to fold axes (Gapais and Le Corre, 1980). During the Variscan orogeny, Eastern Central Brittany underwent a very low-grade metamorphism with an estimated maximum temperature of $250-300{ }^{\circ} \mathrm{C}$, based on vi-trinite reflectance (Donnot et al., 1973), chloritoid-bearing slate oc-currences (Le Corre, 1969), the illite crystallinity (Le Corre, 1975) and the chlorite geothermometer (Gloaguen et al., 2007). Unlike the wes-tern and southern parts of the Armorican Massif, granitic intrusions are relatively scarce in Eastern Central Brittany (Fig. 1) with (1) some late Carboniferous intrusions emplaced at ca. $315 \mathrm{Ma}$, such as the Lizio granite (Tartèse et al., 2011) and the Pontivy-Rostrenen magmatic complex (Ballouard et al., 2017), and (2) the Le Pertre granite with a poorly constrained emplacement age at ca. $340 \mathrm{Ma}$ (Vernhet et al., 2009). Central Brittany is also marked by a widespread swarm of do-lerite dykes and sills dated at $363.4 \pm 5.8 \mathrm{Ma}$ (U-Pb on apatite, Pochon et al., 2016b). These mafic rocks are characterized by geochemically homogeneous compositions with no significant crustal input, inter-preted as a within-plate like alkaline continental basalts (Pochon et al., 2016b). Antimony and gold mineralization, such as the Le Semnon Sb-Au district (Chauris et al., 1985; Pochon et al., 2016a; Gloaguen et al., 2016b), are geometrically associated with these mafic rocks.

Most Sb-Au occurrences - with the exception of the Vendée district - are localized within Central Brittany and along the northern branch of SASZ (Fig. 1). Sb-Au ore deposits generally consist of stibnite-gold bearing quartz lodes, such as the world-class La Lucette mine ( $42 \mathrm{kt} \mathrm{Sb}$ and $8.4 \mathrm{t} \mathrm{Au}$ ) or the Le Semnon district with an estimated reserve of $45 \mathrm{kt} \mathrm{Sb}$ and $3.3 \mathrm{t} \mathrm{Au}$ (Gloaguen et al., 2016b). According to Chauris and Marcoux (1994), the source of antimony in the Armorican Massif could be pre-Variscan, resulting probably from various felsic magmatic events spanning the Cambrian-Carboniferous period (Marcoux et al., 1984). In this scenario, the antimony was remobilized by late Variscan magmatic and hydrothermal events and deposited around $300 \mathrm{Ma}$ within Late Variscan shear zones at shallow depths such as those found in the French Massif Central (Boiron et al., 1989, 2003; Bouchot et al., 2005). This short-time and large-scale fluid flow is contemporaneous with granite emplacement and associated $\mathrm{W} \pm \mathrm{Sn}$ deposits, which resulted from thermal events related to the post-thickening collapse of the Variscan Orogen (Costa and Rey, 1995; Bouchot et al., 2005). More recently, a strong spatial statistical correlation between $\mathrm{Sb}( \pm \mathrm{Au})$ occurrences and relatively high density and magnetic zones has been demonstrated (Pochon et al., 2016a). These high density and magnetic zones might correspond to the occurrence at depth of mafic/ultramafic bodies, which have been interpreted as magma chambers responsible for the emplacement of the numerous dolerite dyke and sill swarms observed close to the paleo-surface in Central Brittany. These dolerites, such as the ones found in the Le Semnon area (Fig. 1), have been re-cently dated at ca. $360 \mathrm{Ma}$ (Pochon et al., 2016b).

\subsection{The Le Semnon Sb-Au district}

The Le Semnon Sb-Au district is located in the center of Central Brittany, far away from the NASZ and the northern branch of the SASZ (Fig. 1). The district consists of a $\mathrm{N} 120^{\circ} \mathrm{E}$ striking, near vertical, dolerite dyke swarm intrusive in Lower to Middle Ordovician slates (Fig. 2), locally called "Formation d'Angers-Traveusot".

These slates are fine-grained and low-grade metapelites (Le Corre, 1969, 1975; Donnot et al., 1973), mainly composed of quartz, sericite and chlorite and they are affected, as above mentioned, by upright folds and by a E-W trending sub-vertical cleavage. The dolerite dyke swarm is about $17 \mathrm{~km}$ in length, $3 \mathrm{~km}$ in width (Gloaguen et al., 2016b). Dyke thicknesses are variable, from 1 to $25 \mathrm{~m}$, and their length is around $500 \mathrm{~m}$. The dolerite dyke from the historical Le Semnon mine is about $10 \mathrm{~m}$ wide with a minimal length of 350 $\mathrm{m}$ and is steeply dipping $\left(85^{\circ}\right)$ to the north. All dykes are folded and are heterogeneously affected by the regional cleavage depending on their size. Small dykes are strongly affected by the cleavage whereas only the walls of the large dykes are affected. The district is also marked by a network of N160$170^{\circ} \mathrm{E}$ trending dextral transtensional wrench faults (Fig. 2). According to Chauris et al. (1985), the trending of dolerite dykes and faults is con-sistent with the regional-scale dextral simple shear of Central Brittany.

$\mathrm{Sb}-\mathrm{Au}$ occurrences and deposits are spatially associated with do-lerite dykes as shown by numerous mining exploration works and by the high $\mathrm{Sb}$ content (> $100 \mathrm{ppm}$ ) found close to the dykes (Fig. 2). Sb-Au mineralization consists of a network of irregular quartz-carbonate veins, up to $80 \mathrm{~cm}$ thick, crosscutting the contact between the dolerite dyke and slates. Three main stages have been identified in the para-genetic sequence (Chauris et al., 1985): (1) an early $\mathrm{Fe}-\mathrm{As}-(\mathrm{Au})$ stage made of arsenopyrite, pyrite and pyrrhotite commonly replaced by pyrite and marcasite, (2) an intermediate $\mathrm{Fe}$-Sb stage characterized by berthierite and (3) a final Sb stage with massive stibnite and rare native antimony. One of the major characteristics of the Le Semnon deposit is the strong dissemination of arsenopyrite at the contact between the dolerite dyke and the slates, which consequently underlines a strong Asbearing hydrothermal alteration zone in the country rocks. Gold can be found: (1) in the crystal lattice of arsenopyrite, with a mean content of about 200 ppm (Gloaguen et al., 2016b), (2) in native form in quartz veins, arsenopyrite and stibnite, or (3) in aurostibite within stibnite (Chauris et al., 1985). Hydrothermal alteration is characterized by carbonation, as revealed by the destruction of calcic plagioclase and clinopyroxene and by the presence of ankerite and calcite in the groundmass, by potassic metasomatism, as highlighted by sericitized plagioclase and hydrothermal illite in the groundmass of the hydro-thermally altered dyke, and by a weak silicification (Pochon et al., 2017). All the magmatic Fe-Ti oxides, represented by ilmenite and il-menite-hematite solid solution, are totally replaced by rutile and leucoxene at the beginning of hydrothermal event (Chauris et al., 1985; Pochon et al., 2017). During the breakdown of the ilmenite-hematite assemblage into rutile, rutile incorporated $\mathrm{Sb}(\sim 100 \mathrm{ppm})$ suggesting that the fluid was already enriched in $\mathrm{Sb}$ at the early stage of hydro-thermal alteration (Pochon et al., 2017). Sb-Au mineralization is con-sidered to be syn- to post-kinematic by Marot (1984) because some Sb-veins are affected by the regional cleavage. Cleavage planes can contain "rosette"-type stibnite or being crosscut by massive stibnite, while pressure shadows of arsenopyrite can contain native antimony and acicular stibnite (Marot, 1984).

\section{Material and methods}

\subsection{Mineral chemistry}

Arsenopyrite from hydrothermally altered slates was examined in polished thin-sections using reflected-light optical microscope and scanning electron microscope (SEM) equipped with energy dispersive X-ray spectrometer (EDS), and analyzed using Cameca SX-100 electron probe micro-analyzers at IFREMER (Brest, France) and Cameca SX-50 at BRGM (Orléans, France). Analyses were mainly performed in order to check the Au and $\mathrm{Sb}$ content and to estimate the crystallization tem-perature of arsenopyrite according to experimental data of Sharp et al. (1985). The major and minor elements analyzed are Fe, S, As, Sb, Bi, Au, Zn, Cu, Ni, Co, Ag, Se. Analyses were performed using a $3 \mu \mathrm{m}$ diameter beam, a $15-20 \mathrm{kV}$ accelerating voltage, a beam current of $20 \mathrm{nA}$ and a counting time of $20 \mathrm{~s}$ on peak. Concerning phyllosilicates and carbonates from hydrothermally altered dolerite, slates, and veins, they were also examined in polished thin-sections using SEM equipped with EDS. Minerals were analyzed using Cameca SX100 electron probe micro-analyzers at IFREMER (Brest, France). Elements analyzed are $\mathrm{Si}, \mathrm{Al}, \mathrm{Ti}, \mathrm{Fe}, \mathrm{Mg}, \mathrm{Mn}, \mathrm{Ca}, \mathrm{Ba}, \mathrm{Na}, \mathrm{K}, \mathrm{V}, \mathrm{Cr}$. Analyses were performed using a $3 \mu \mathrm{m}$ diameter beam, a $15 \mathrm{kV}$ accelerating voltage, a beam current of $20 \mathrm{nA}$ and a counting time of $20 \mathrm{~s}$ on peak.

\subsection{Fluid inclusion}

Fluid inclusions from $150 \mu \mathrm{m}$-thick doubly polished wafers have 


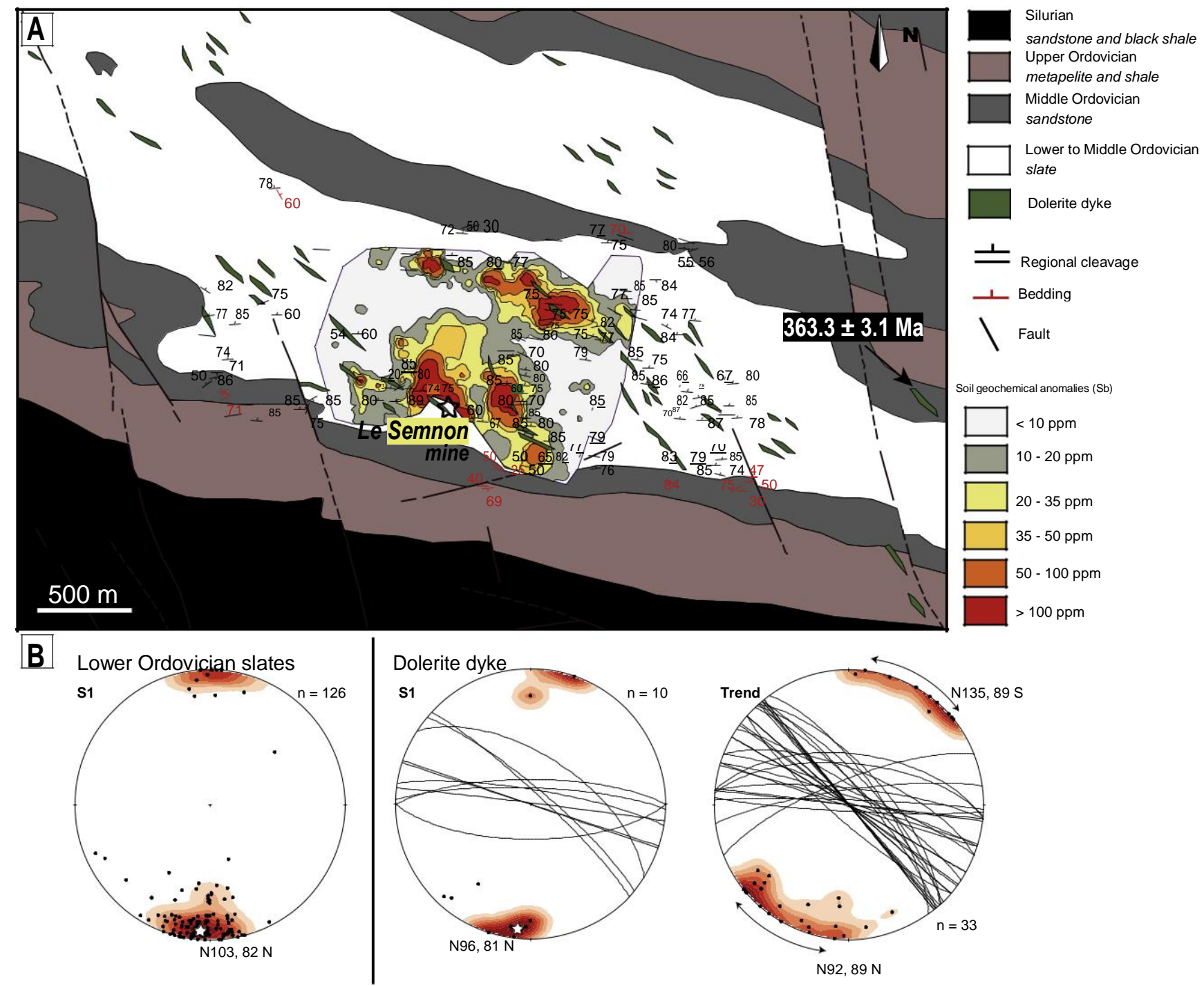

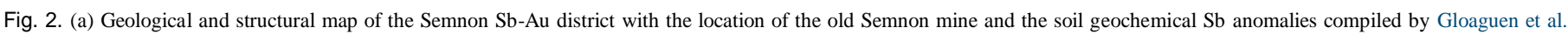

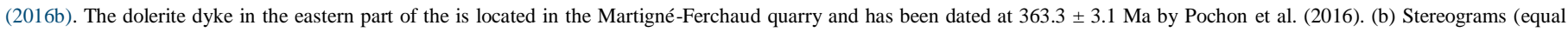

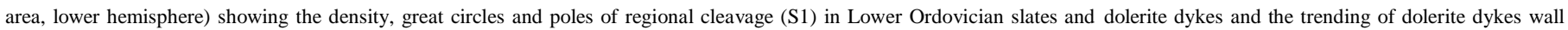
rocks (Trend) modified from Marot (1984).

been carefully investigated and correlated with the paragenetic se-quence of mineral crystallization within the mineralized veins to con-strain the conditions of fluid flow and $\mathrm{Sb}-\mathrm{Au}$ deposition. In order to check the chronology of fluid events, typology and petrography of fluid inclusions from representative samples have been studied by looking at the relationship between fluid inclusions, quartz and the location of ore minerals.

Microthermometric characterization of fluid inclusions was carried out using an Olympus BX 51 transmitted optical microscope equipped with a heating-freezing Linkam THMS 600 at the GeoResources la-boratory in Nancy (France) in order to measure temperatures for $\mathrm{H}_{2} \mathrm{O}$ melting $\left(\mathrm{Tm}\left(\mathrm{H}_{2} \mathrm{O}\right)\right), \mathrm{CO}_{2}$ melting $\left(\mathrm{Tm}\left(\mathrm{CO}_{2}\right)\right)$, clathrate melting $(\mathrm{Tm}(\mathrm{Cl})), \mathrm{CO}_{2}$ homogenization $\left(\mathrm{Th}\left(\mathrm{CO}_{2}\right)\right.$ ) and total homogenization $(\mathrm{Th})$. The standards used for calibration were natural or synthetic fluid in-clusions, including a $\mathrm{CO}_{2}-\mathrm{H}_{2} \mathrm{O}$ fluid inclusion with a $\mathrm{Tm}\left(\mathrm{CO}_{2}\right)$ at $-56.6{ }^{\circ} \mathrm{C}$ and a pure $\mathrm{H}_{2} \mathrm{O}$ fluid inclusion with $\operatorname{Tm}\left(\mathrm{H}_{2} \mathrm{O}\right)$ at $0{ }^{\circ} \mathrm{C}$. Typology of fluid inclusions (aqueous carbonic and aqueous inclu-sions) is determined following the nomenclature of Boiron et al. (1992).

Molar fractions of gas species $\left(\mathrm{CO}_{2}, \mathrm{CH}_{4}, \mathrm{H}_{2} \mathrm{~S}\right.$ and $\left.\mathrm{N}_{2}\right)$ were de-termined in aqueous carbonic representative inclusions, previously studied by microthermometry, with a Raman microspectrometer at the
GeoResources laboratory. The bulk composition, molar volume, volatile/water ratio and salinity were calculated from the P-V-T-X proper-ties of individual aqueous carbonic inclusions in the C-O-H-S system (Dubessy, 1984; Dubessy et al., 1989; Thiéry et al., 1994; Bakker, 1999). Isochores were calculated using the program ISOC from the computer package FLUIDS-1 (Bakker et al., 2003) based on data from Bowers and Helgeson (1983).

\subsection{Stable isotopes}

Calcite samples, except for SEM62 sample, come from the collection of the museum of Géosciences Rennes (France) because calcite crystals are relatively rare in the available outcrops found at the Le Semnon mine. Ankerite crystals are relatively abundant and were collected from fresh outcrops. Samples were crushed in agate mortar or reduced in powder by microdrilling, depending on their size. A minimum of about $12 \mathrm{mg}$ of powder were collected for each sample. Powders were reacted with anhydrous $\mathrm{H}_{3} \mathrm{PO}_{4}$, at $50{ }^{\circ} \mathrm{C}$. Reaction times were a few hours for calcite and about $36 \mathrm{~h}$ for ankerite. The $\mathrm{O}$ and $\mathrm{C}$ isotope compositions were measured using a VF Delta Isoprime triple-collector mass spec-trometer at Géosciences Rennes. Repeated measurements of 

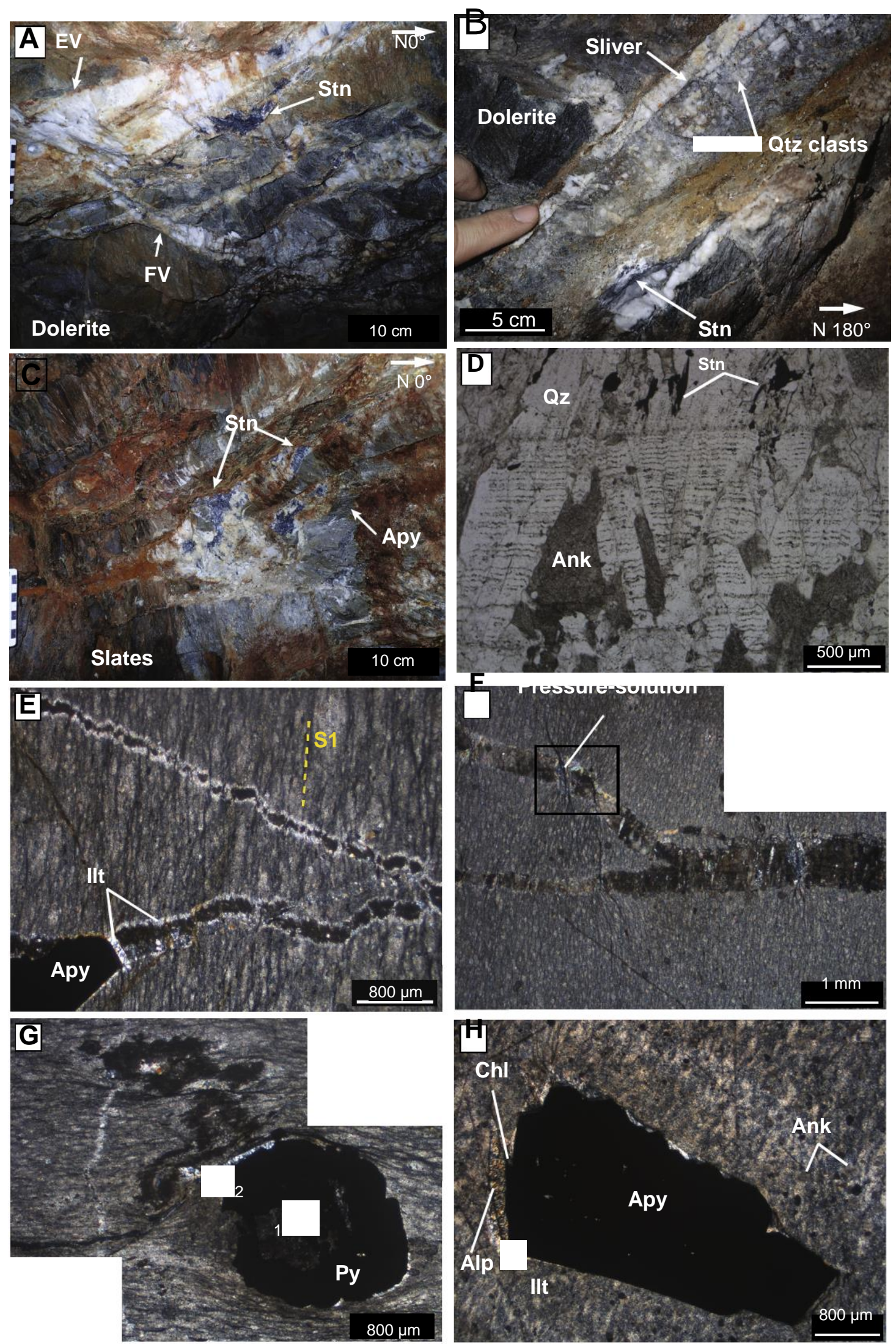


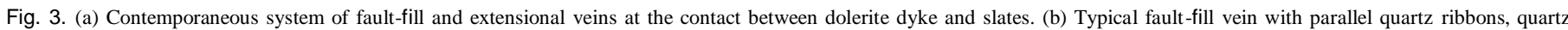

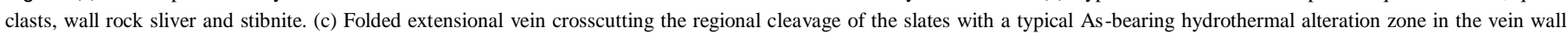

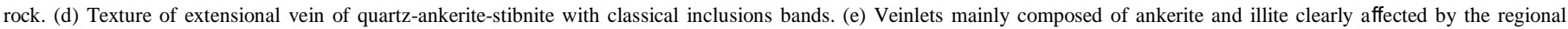

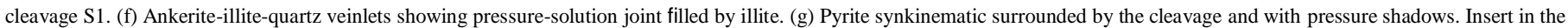

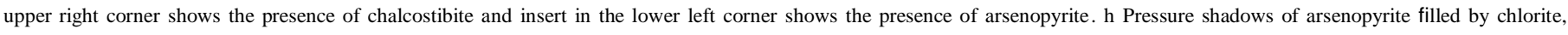

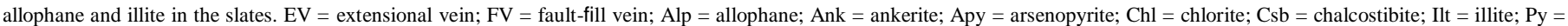
pyrite; Qz = quartz; Stn = Stibnite. Mineral abbrevia-tions from Whitney and Evans (2010).

international and in-house standards allow estimating uncertainties at $\pm 0.1 \%$ and $\pm 0.2 \%$ for $\mathrm{C}$ and $\mathrm{O}$ isotope values respectively. Results are reported using the delta notation, with PDB and SMOW as refer-ences for the $\mathrm{C}$ and $\mathrm{O}$ isotope systems, respectively.

\subsection{Geochronology}

\subsubsection{U-Pb dating}

Apatite and rutile crystals, from the hydrothermally altered dolerite dyke of the Le Semnon mine, were carefully examined in polished thin-sections using reflected-light optical microscope and apatite were im-aged by cathodoluminescence (CL) using a Reliotron CL system equipped with a digital color camera available in Géosciences Rennes.

$\mathrm{U}-\mathrm{Pb}$ dating of apatite and rutile was performed by in-situ laser ablation inductively coupled plasma mass spectrometry (LA-ICP-MS) at Géosciences Rennes using a ESI NWR193UC excimer laser coupled to a quadripole Agilent 7700x ICP-MS equipped with a dual pumping system to enhance sensitivity (Paquette et al., 2014). The instrumental conditions and analytical procedures are reported in Appendix A.1. Further information about the apatite and rutile method dating can be found in Pochon et al. (2016b) and Boutin et al. (2015), respectively.

An ablation rectangle corresponding to a spot of 50 and $40 \mu \mathrm{m}$ was defined for ablation laser of the apatite and rutile grains, respectively. Data were corrected for $\mathrm{U}-\mathrm{Pb}$ fractionation and for mass bias by the repeated measurements of the Madagascar apatite standard (473.5 $\pm 0.7 \mathrm{Ma}$; Cochrane et al., 2014) and the R10 rutile standard (Zack et al., 2011) for apatite and rutile, respectively. The apatite standards McClure $(523.51 \pm 2.09 \mathrm{Ma}$; Schoene and Bowring, 2006) and Durango (31.44 $\pm 0.18 \mathrm{Ma}$; McDowell et al., 2005) and the rutile standard R19 (489.5 $\pm 0.9 \mathrm{Ma}$; Zack et al., 2011) were treated as un-knowns and used to monitor precision and accuracy of the analyses. They provided $207 \mathrm{~Pb}$ corrected ages of $529.7 \pm 5.7 \mathrm{Ma}(\mathrm{N}=8$,

MSWD = 3.1 $), \quad 31.47 \pm 0.87 \mathrm{Ma} \quad(\mathrm{N}=9, \quad \mathrm{MSWD}=2.7) \quad$ and $476 \pm 30 \mathrm{Ma}(\mathrm{N}=5, \mathrm{MSWD}=1.6)$, respectively.

Data reduction was carried out with the data reduction scheme VizualAge_UcomPbine, a set of Iolite procedures that work with Igor Pro (Chew et al., 2014) for apatite and with the GLITTER® software package developed by the Macquarie Research Ltd. (Van Achterbergh et al., 2001) for rutile. Apatite and rutile ages were calculated and plotted in a TeraWasserburg diagram using Isoplot/Ex software (Ludwig, 2012) and errors are provided at $2 \sigma$ level.

\subsection{2. ${ }^{39} \mathrm{Ar}-{ }^{40} \mathrm{Ar}$ dating}

Euhedral to subeuhedral illite crystals, selected for ${ }^{40} \mathrm{Ar} /{ }^{39} \mathrm{Ar}$ dating, were carefully handpicked under a binocular microscope from the 0.25-1.0 $\mathrm{mm}$ fractions and analyzed by step-heating with an ${ }^{40} \mathrm{Ar} /{ }^{39} \mathrm{Ar}$ laser probe at Géosciences Rennes, following the analytical procedure described in Ruffet et al. (1991, 1995). Details on the method and analytical data are given in Appendix A.2. The samples were wrapped in Al foil to form small packets $(11 \times 11 \mathrm{~mm})$ that were stacked up to form a pile, within which packets of fluence monitors were inserted every 8 samples. The stack, placed in an irradiation can, was irradiated for c. $195 \mathrm{~h}$ at the McMaster reactor (Hamilton, Canada) with a $\mathrm{J} / \mathrm{h}$ of c. $5.4 \times 10^{-5} \mathrm{~h}^{-1}$. Analyses were performed on a Map215® mass spectrometer. To define a plateau age, a minimum of three consecutive steps are required, corresponding to a minimum of
$70 \%$ of the total ${ }^{39}$ ArK released, and the individual fraction ages should agree to within $1 \sigma$ or $2 \sigma$ of the integrated age of the plateau segment. Pseudoplateau ages, with less than $70 \%$ of ${ }^{39} \mathrm{ArK}_{\mathrm{K}}$ released, can also be defined. Errors are provided at the $1 \sigma$ level.

\section{Results}

\subsection{Sb-Au mineralization of the Le Semnon deposit}

\subsubsection{Vein geometry and microstructures}

In agreement with previous studies (Marot, 1984; Chauris et al., 1985; Gloaguen et al., 2016b), two types of Sb-Au veins were dis-tinguished. They consist of $\mathrm{cm}$-scale fault-fill veins and $\mathrm{mm}$ to $\mathrm{cm}$-scale extensional veins (Fig. $3 a-c)$. Sb-Au veins are preferentially localized at the contact between the slates and the dolerite dyke and become sparse away from the contact $(\sim 1 \mathrm{~m})$. The first type occurs along reverse faults and consists of an average of $\mathrm{N} 84^{\circ} \mathrm{E}-$ striking veins with a dip of $49^{\circ}$ to the north (Fig. 4 a). These veins typically have a banded texture where quartz ribbons are separated by slivers of altered wall rock (slates or dolerite) impregnated with stibnite and contain clasts of quartz (Fig. 3b). The second type is contemporaneous with fault-fill vein and corresponds to a network of $\mathrm{N} 91^{\circ} \mathrm{E}$-striking flat veins with a mean dip of $11^{\circ}$ to the south (Fig. 4a). Extensional veins are filled by elongate blocky and fibrous quartz and carbonates mainly growing from the vein wall toward the center of the vein indicating the exten-sion component of the veins. At a microscopic scale, quartz and car-bonate crystals frequently host solid inclusions bands and trails (Fig. 3d), which is the main feature of the crackseal mechanism in-dicating a process of repeated cracking and intermittent sealing (Ramsay, 1980). These veins cut across the sub-vertical regional cleavage and reciprocally (Fig. 3c, e). In the extensional veinlets hosted by the slates, where regional deformation is well-expressed when com-pared to the large dyke of the Le Semnon mine, cleavage frequently crosscut them showing mm-scale offsets (Fig. 3e). Veinlets are also af-fected by pressuresolution mechanism accompanied by a neo-crystal-lization of illite at the pressure-solution joint (Fig. 3f). Within the slates, disseminated arsenopyrite and pyrite crystals show also kinematic cri-teria because they were generally surrounded by cleavage (Fig. $3 \mathrm{~g}$ ) and numerous pressure shadows can be observed around them (Fig. 3g, h). The vein geometry and microstructures observed in the Le Semnon deposit are summarized in Fig. 4.

\subsubsection{Mineralogy of the Le Semnon Sb-Au deposit}

Quartz is the main filling constituent ( $70 \mathrm{vol} \%)$ of the Sb-Au veins and typically contains numerous inclusion trails of carbonates and illite (Figs. 3d and 5a), suggesting synchronous and repeated deposition of these three minerals. In fault-fill vein, quartz is banded (Fig. 3b) and commonly white; whereas it is typically elongate blocky and grey translucent in extensional veins. In these latter veins, quartz may be deformed as shown by undulose extinction and sub-grains formation. These sub-grains are frequently accompanied by neo-crystallization of carbonates and illite (Fig. 5c). Carbonates constitute an average volume of 25 to $30 \mathrm{vol} \%$ in the vein gangue but they may reach up to $80 \mathrm{vol} \%$ in veinlets. They also constitute the main minerals markers of hydro-thermal alteration within host rocks. Although calcite can be abundant, carbonates are mostly represented by ankerite (Appendix A.3) with an 

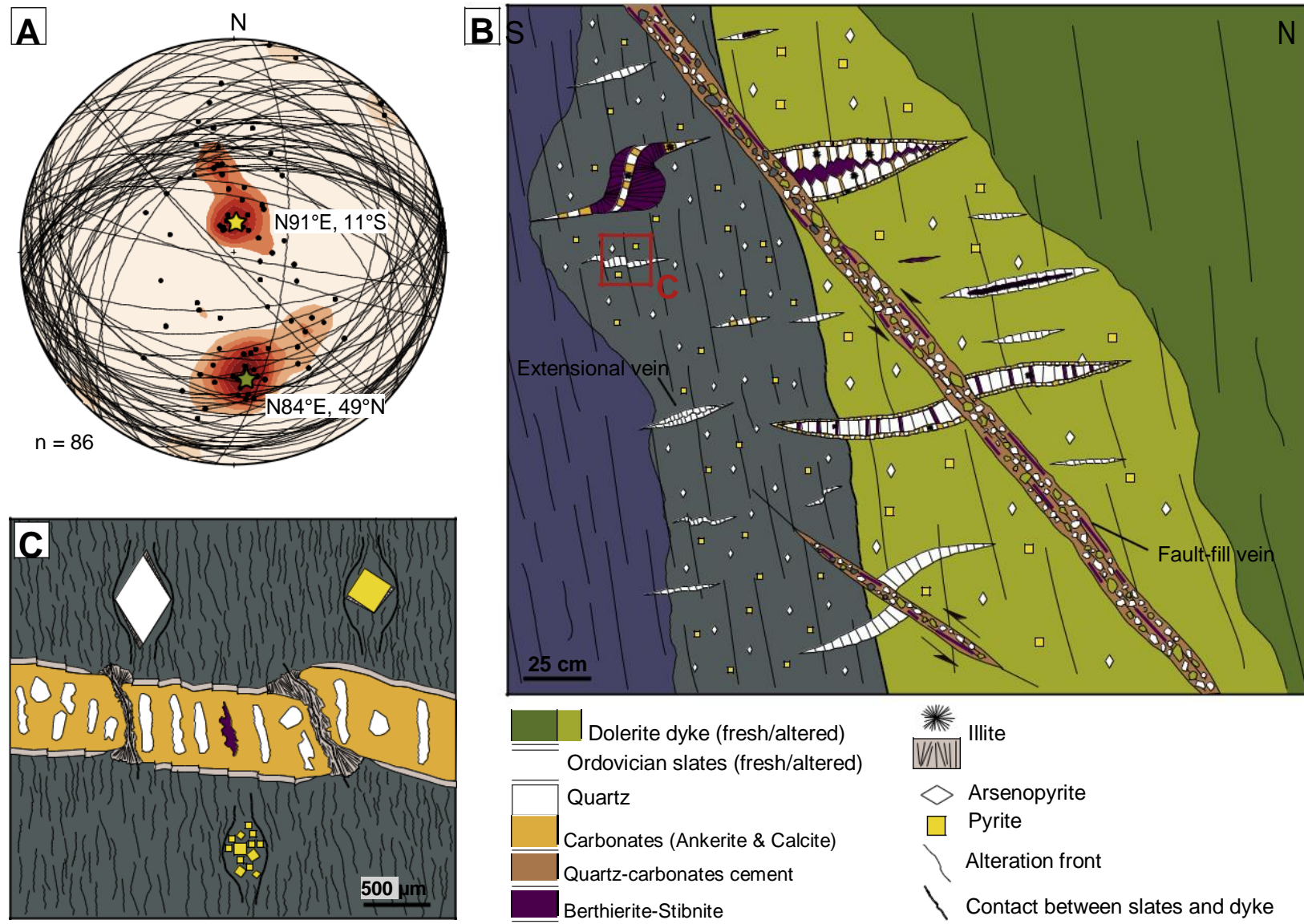

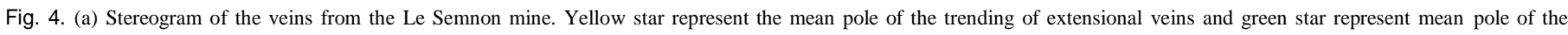

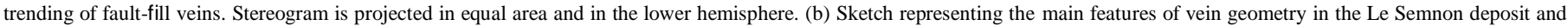

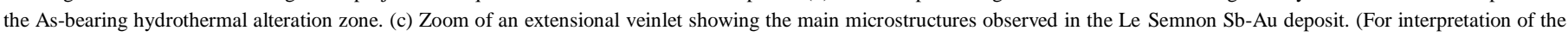
references to color in this figure legend, the reader is referred to the web version of this article.)

average composition of $51.9 \% \mathrm{CaCO}_{3}, 27.5 \% \mathrm{MgCO}_{3}, 19.5 \% \mathrm{FeCO}_{3}$ and $1 \% \mathrm{MnCO}_{3}$.

Carbonate (ankerite and calcite) is characterized by euhedral crys-tals up to $500 \mu \mathrm{m}$ in size. It hosts numerous solid inclusion bands such as the quartz crystals. It typically contains numerous inclusions of berthierite and stibnite and can be therefore related to the main Sb mineralization (Fig. 5b). Locally, carbonate can be associated with pyrite, pyrrhotite and sphalerite. White mica is represented by illite in composition $\left(\left(\mathrm{K}_{0.63} \mathrm{Na}_{0.07} \mathrm{Ca} 0.01\right)\right.$ $\left(\mathrm{Al}_{2.01} \mathrm{Fe}_{0.02} \mathrm{Mg}_{0.03}\right)\left(\mathrm{Si}_{3} .12 \mathrm{Al}_{0.88} \mathrm{O}_{10}\right)(\mathrm{OH})_{2} \cdot 2 \mathrm{H}_{2} \mathrm{O}$, Appendix A.4). It is found within veins and in the wall rock alteration. Illite is characterized by aggregates of poly-grains up to $250 \mu \mathrm{m}$ in size. It can form mm-scale veinlets alone, clusters at the boundary of quartz and carbonates grains (Fig. 5c) or be found at the edges of the veins (Fig. 3e). Illite may contain acicular stibnite and berthierite between its sheets (Fig. 5d). Illite is also found in the pres-sure shadows around arsenopyrite and pyrite (Fig. 3g), locally with chlorite and allophane (Fig. 3h). Chlorite and allophane are relatively scarce in the deposit and are closely associated with illite.

Arsenopyrite is the dominant sulfide in the hydrothermally altered dolerite dyke and slates, while it is almost absent in veins, and re-presents the earliest sulfide in the mineralization. It forms euhedral grains up to $1 \mathrm{~cm}$ in size with rhomb shape. It is frequently associated with pyrite and hosts numerous inclusions of rutile, pyrite, chalcostibite and sphalerite (Fig. 5e).

Arsenopyrite $(\mathrm{n}=122)$ has an average chemical composition of 30.7 at.\% As, 33.3 at.\% $\mathrm{Fe}$ and 0.2 at.\% $\mathrm{Sb}$ (Appendix A.5). Using the arsenopyrite geothermometer of Kretschmar and Scott (1976) modified by Sharp et al. (1985) and assuming that crystallization began at the pyrite-pyrrhotite buffer because pyrrhotite is decomposed into pyrite and that arsenopyrite is in textural equilibrium with pyrite, a tem-perature of crystallization can be estimated at around $360{ }^{\circ} \mathrm{C}$ (Appendix A.6). Like arsenopyrite, pyrite is scarce in the veins and rather dis-seminated in the hydrothermally altered country rocks. It forms fre-quently aggregates of euhedral to sub-euhedral crystals with a milli-metric grain size. Pyrite is associated with arsenopyrite and hosts many inclusions of chalcostibite, sphalerite and rutile. Pyrrhotite is relatively rare in the deposit forming irregular anhedral porous grains up to $1 \mathrm{~mm}$ in size. It is commonly transformed into pyrite.

Berthierite is rather abundant in both fault-fill and extensional vein types and also in dissemination in the veins present in the wall rock. It is associated with intergrown carbonates and its precipitation happened prior to the deposition of stibnite. Berthierite contains inclusions of native antimony and native gold and is always found partially replaced by stibnite (Fig. 5d), likely due to its narrow stability range of oxygen and sulfur fugacity compared to stibnite (Williams-Jones and Normand, 1997). Stibnite is the most abundant sulfide in both types of veins and appears to be the last sulfide in the paragenetic evolution. Conse-quently, it can be found in various textural positions. Two types of stibnite were distinguished: fine- to coarse-grained stibnite replacing berthierite (Fig. 5d) and stibnite associated with carbonates. The latter type of stibnite is mainly massive and coarse-grained and overgrows quartz and illite, fills micro-cracks in arsenopyrite (Fig. 5f) or spha-lerite, intergranular spaces, pressure shadows (Fig. 5f, g) or geodic cavities. The two types of stibnite may also be found in dissemination or replacing disseminated berthierite within the hydrothermally altered dolerite dyke and slates. Stibnite contains rare inclusions of 

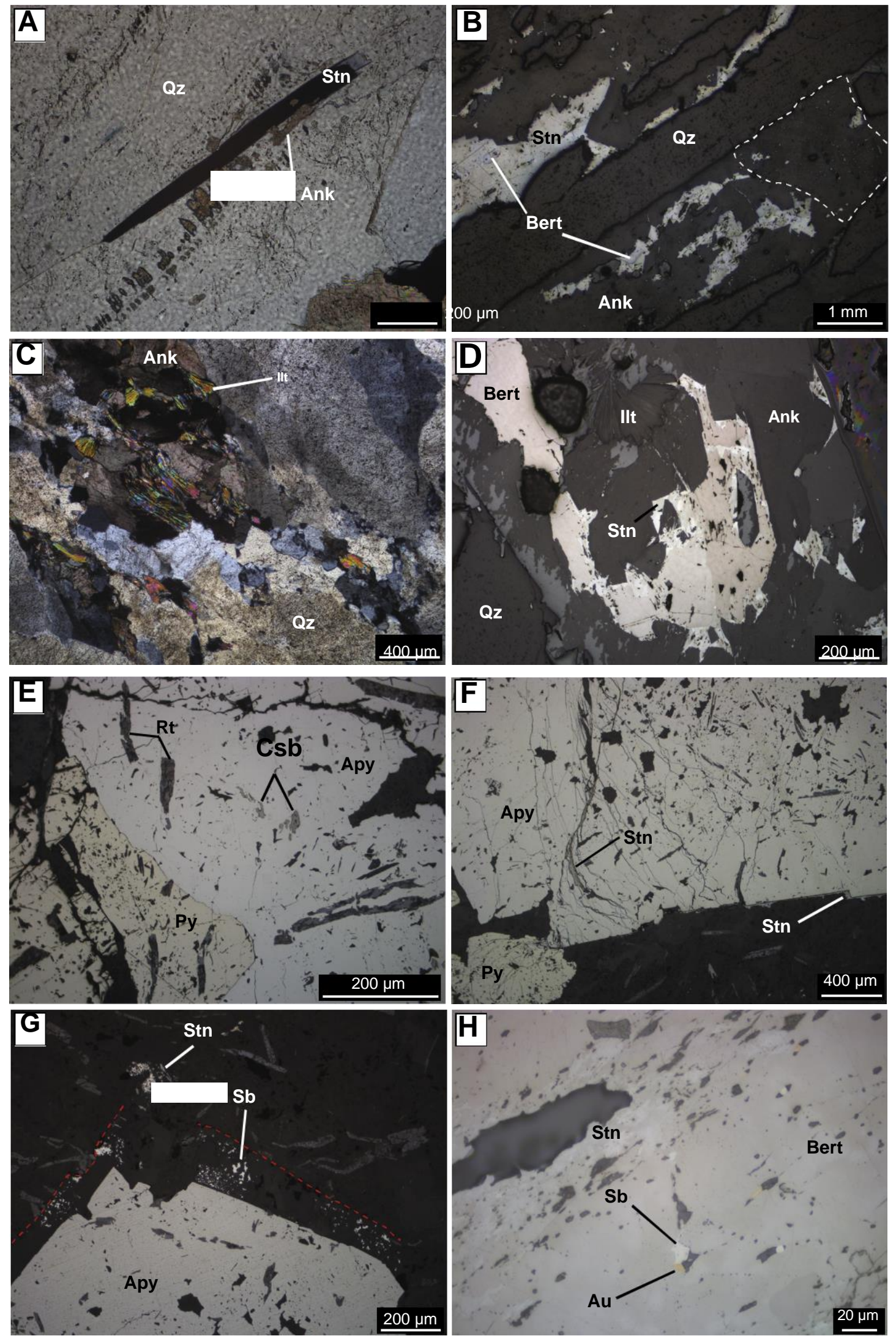

Fig. 5. (a) Inclusions trail of ankerite within quartz crystal and stibnite needle at the boundary between two quartz crystals. (b) Typical relationships between elongate blocky quartz, ankerite, berthierite and stibnite. White dashed line shows the numerous micro-inclusions of stibnite hosted by ankerite. (c) Sub-grains of quartz with the neocrystallization of illite and ankerite at the boundary of sub-grains. (d) Common replacement of berthierite by stibnite within ankerite. Stibnite also crystallizes between sheets of illite. (e) Arsenopyrite and pyrite association with many inclusions of chalcostibite and rutile. (f) Fracture and pressure shadow filled by stibnite in arsenopyrite. (g) Native antimony and stibnite within pressure shadow of arsenopyrite. (h) Inclusions of native gold and antimony within berthierite partially replaced by stibnite. Ank = ankerite; Apy = arsenopyrite; Bert $=$ berthierite; Csb $=$ chalcostibite; Ilt $=$ illite; $\mathrm{Py}=$ pyrite; $\mathrm{Qz}=$ quartz; $\mathrm{Rt}$ = rutile; $\mathrm{Sb}=$ native antimony; $\mathrm{Stn}=$ Stibnite. Mineral abbreviations from Whitney and Evans (2010). 

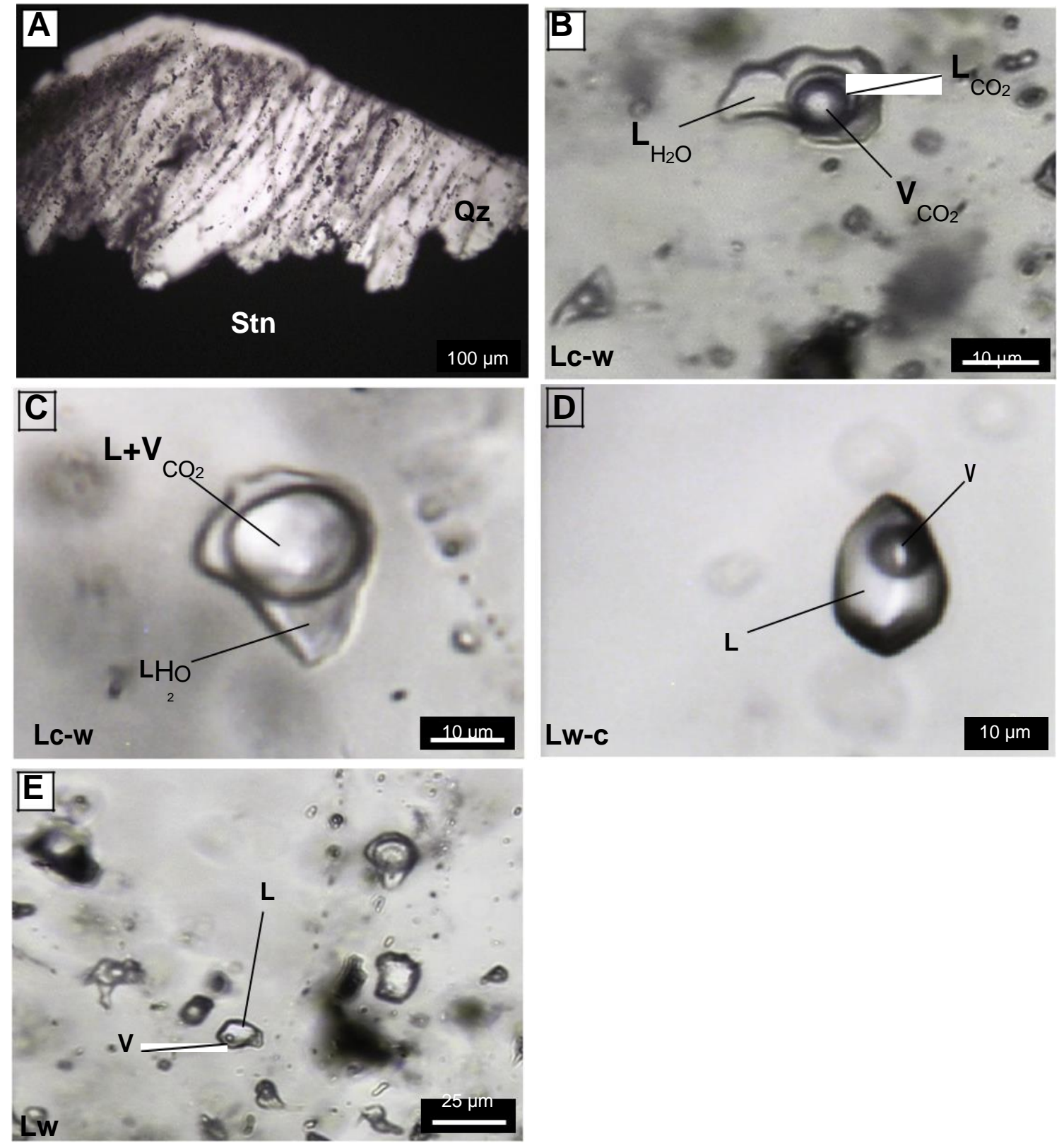

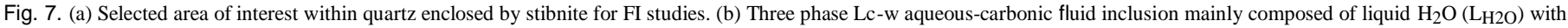

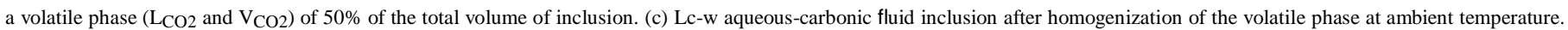
(d) Lw-c aqueous-carbonic fluid inclusion. (e) Lw aqueous fluid inclusions with a small vapor phase (10\%).

comprised between 137 and $310{ }^{\circ} \mathrm{C}$. Aqueous FIs are very rare, smaller than aqueous-carbonic FIs $(<10 \mu \mathrm{m})$, and have relatively low homo-genization temperatures ranging between 115 and $154^{\circ} \mathrm{C}$.

The composition of the volatile phase of aqueous-carbonic FIs is mostly dominated by $\mathrm{CO}_{2}$, with a very low $\mathrm{CH}_{4}$ content, but is locally enriched in $\mathrm{N}_{2}$ (up to $28.8 \mathrm{~mol} \%$, Appendix A.7). Compositional changes in the volatile phase are related to a decrease in its density (Fig. 8b). Values of Lc-w inclusion type are about $0.55 \mathrm{~g} / \mathrm{cm}^{3}$, whereas $\mathrm{Lw}-\mathrm{c}$ inclusions values are around $0.12 \mathrm{~g} / \mathrm{cm}^{3}$. FIs with the lowest densities are characterized by the highest water contents $\left(\sim 95 \mathrm{~mol} \% \mathrm{H}_{2} \mathrm{O}\right)$, a decrease of the $\mathrm{CO}_{2}$ content and an enrichment in $\mathrm{CH}_{4}$ and $\mathrm{N}_{2}$ (Fig. 8b, c). All these features define a characteristic and continuous time evolution (Boiron et al., 2003). Fig. 8d shows that fluids of the Le Semnon deposit have an evolution trend from hot aqueous-carbonic fluids evolving toward cooler aqueous-carbonic and aqueous fluids.

\subsection{Stable isotopes}

Carbonates from some extensional veins were analyzed for oxygen and carbon isotopes (Table 2, Fig. 9). The three samples of ankerite (LS1, SEM33 and SEM43) arise from different stibnite-bearing quartz-ankerite-illite veins collected at the same level (i.e. first level of the mine, $-17 \mathrm{~m}$ ). Five samples of calcite were analyzed: two samples (15-17681 and 15-17683) of white calcite without stibnite from si-milar calcite veins but at distinct levels, two samples (87-14132 and SEM32) of white calcite containing stibnite needles from different veins and one sample (15-17675) of black calcite rich in stibnite inclusions

and in close association with stibnite. Ankerite displays minor varia-tions in $\delta^{13} \mathrm{C}$ (from -13.6 to $-12.6 \%$ ) and in $\delta^{18} \mathrm{O}$ (from 13.9 to

$14.7 \%$ ). Calcite display similar $\delta^{18} \mathrm{O}$ values from 13.6 to $14.4 \%$ and different $\delta^{13} \mathrm{C}$ values compared to ankerite with minor variations from -9.8 to $-9.5 \%$, except for SEM62 sample $\left(\delta^{13} \mathrm{C}=-12.5 \%\right.$ ) and $15-17675$ sample $\left(\delta^{18} \mathrm{O}=\right.$ $22.5 \%$ ). 
Table 1

Summary of the microthermometric data from the different groups of fluid inclusions of the Le Semnon Sb-Au deposit and range of compositions for the volatile phase obtained by Raman spectroscopy.

\begin{tabular}{|c|c|c|c|c|c|c|c|c|c|c|c|}
\hline \multirow[t]{2}{*}{ Fluid Type } & \multirow[t]{2}{*}{$\mathrm{n}$} & \multirow[t]{2}{*}{$\%$ volatile phase } & \multirow[t]{2}{*}{$\mathrm{Tm} \mathrm{CO}_{2}$} & \multirow[t]{2}{*}{$\mathrm{Tm} \mathrm{H}_{2} \mathrm{O}$} & \multirow[t]{2}{*}{$\mathrm{Tm} \mathrm{Cl}$} & \multirow[t]{2}{*}{$\mathrm{Th} \mathrm{CO}_{2}$} & \multirow[t]{2}{*}{ Th } & \multirow[t]{2}{*}{ Mode } & \multicolumn{3}{|c|}{ Composition of the volatile phase $(\% \mathrm{~mol})$} \\
\hline & & & & & & & & & $\mathrm{CO}_{2}$ & $\mathrm{~N}_{2}$ & $\mathrm{CH}_{4}$ \\
\hline$\underset{v}{\mathrm{Lc}-\mathrm{w}:} \underset{\mathrm{CO} 2}{\mathrm{LH} 2 \mathrm{O}-\mathrm{LCO} 2-}$ & 12 & 25 to $60 \%$ & -57.8 to -56.8 & -4.4 to -3.5 & 9.4 to 9.9 & 15.7 to 22.1 & $245^{*}$ to $320^{*}$ & $\mathrm{~L}$ & 89.4 to 92.2 & 6.6 to 9.9 & 0.5 to 0.8 \\
\hline mode & & & $\begin{array}{l}-57.7 \\
12\end{array}$ & $\begin{array}{l}-4.1 \\
5\end{array}$ & $\begin{array}{l}9.7 \\
8\end{array}$ & $\begin{array}{l}20.8 / 20.9(\mathrm{~L}) \\
12\end{array}$ & - & & 6 & & \\
\hline $\begin{array}{l}\text { Lw-c: } \mathrm{LH}_{2} \mathrm{O}-\mathrm{LCO} 2 \\
\text { mode }\end{array}$ & 13 & 10 to $40 \%$ & $\begin{array}{l}-57.8 \text { to }-57.4 \\
-57.4\end{array}$ & $\begin{array}{l}-4.2 \text { to }-2.7 \\
-3.2\end{array}$ & $\begin{array}{l}9.4 \text { to } 10 \\
9.9\end{array}$ & - & $\begin{array}{l}137 \text { to } 310 \\
-\end{array}$ & $\mathrm{L}$ & 70.1 to 99.7 & 0.3 to 28.8 & 0 to 1.4 \\
\hline $\begin{array}{l}\mathrm{n} \\
\mathrm{n}\end{array}$ & 5 & $<10 \%$ & $\begin{array}{l}5 \\
-\end{array}$ & $\begin{array}{l}9 \\
-3.3 \\
1\end{array}$ & $\begin{array}{l}4 \\
-\end{array}$ & - & $\begin{array}{l}8 \\
115 \text { to } 154 \\
4\end{array}$ & $\mathrm{~L}$ & 8 & & \\
\hline
\end{tabular}

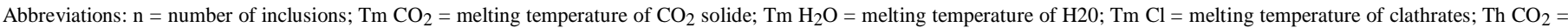
Homogenization temperature of $\mathrm{CO}_{2} ; \mathrm{Th}=$ Homogenization temperature; $\mathrm{L}=$ liquid.

* Decrepitation temperature. Temperatures are given in ${ }^{\circ} \mathrm{C}$.

\subsection{Geochronology}

\subsubsection{U-Pb dating}

Apatite and rutile from the hydrothermally altered dolerite dyke of the Le Semnon mine have been investigated in order to characterize their textural relationships. Apatite consists of euhedral to sub-euhedral grains that are commonly elongated with an acicular shape up to $800 \mu \mathrm{m}$ in length and 50 $\mu \mathrm{m}$ wide. Apatite crystals exhibit blue purplish luminescence, a systematic zoning from the rim (light blue purple) to-ward the core (dark blue purple) and are frequently patchy zoned. Cathodoluminescence reveals overgrowths of recrystallized apatite at the rims and micro-cracks (Fig. 10a, b). Apatite crystals of the Le Semnon dyke are almost systematically cracked and the $\mu \mathrm{m}$-scale cracks, generally filled by carbonates or illite (Fig. 10a-c), delimit micro-blocks of apatite which can be tilted such as a fracture boudinage of a brittle layer embedded in a much more ductile matrix (Fig. 10b). Apatite can be found in the groundmass or enclosed within quartz and carbonates and in very frequent association with rutile suggesting a textural equilibrium (Fig. 10c, d). Rare apatite grains have been ob-served inside the $\mathrm{Sb}$-bearing quartz veins close to the wall and per-pendicular to blocky elongate quartz. Rutile comes from the breakdown of the magmatic ilmenite-hematite assemblage during a hydrothermal
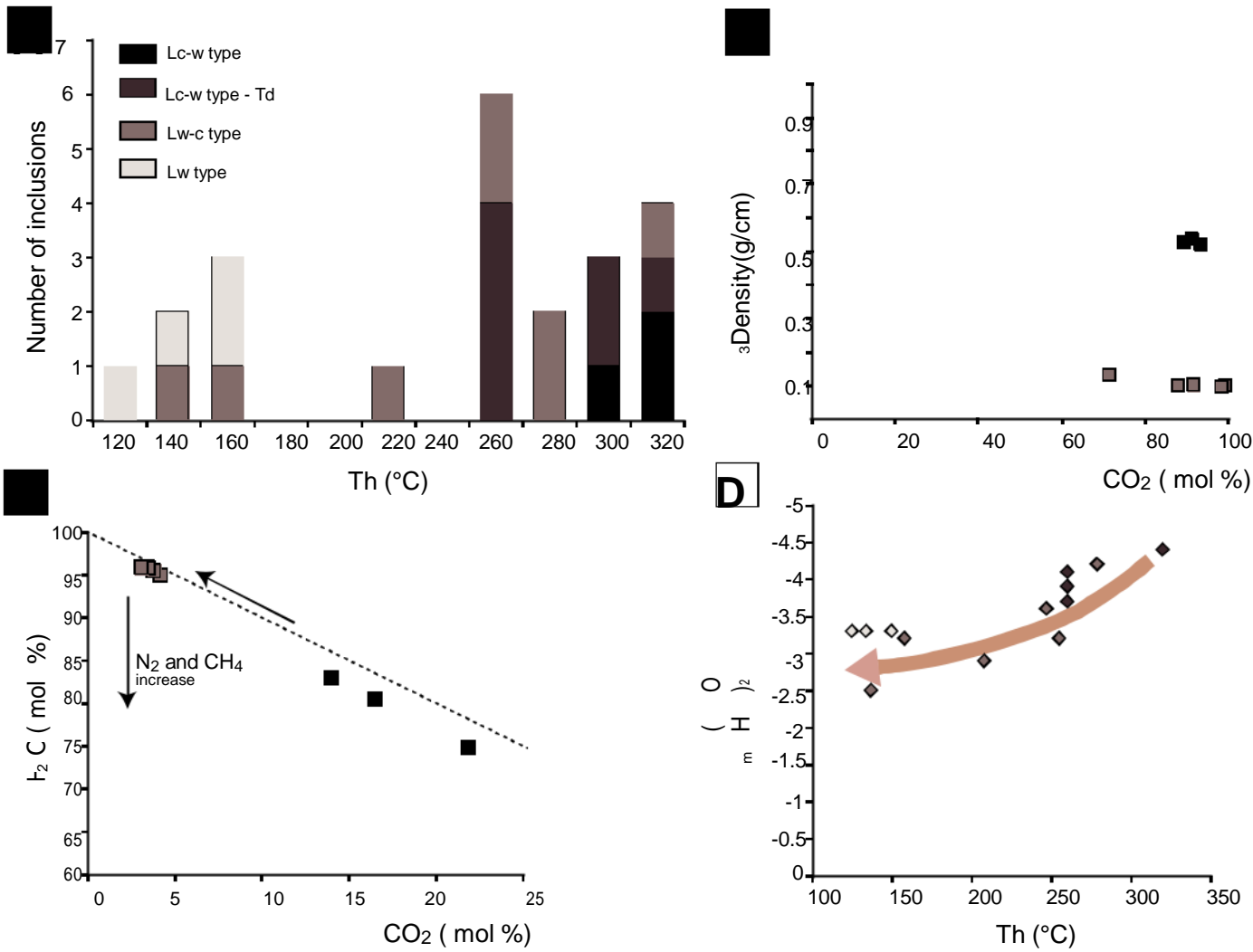

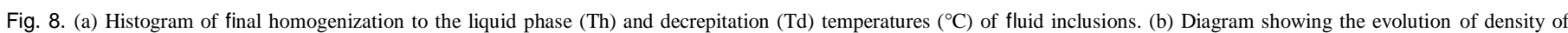

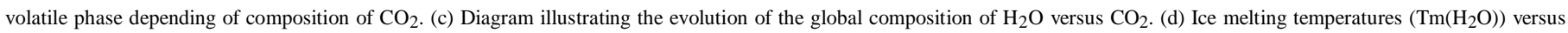
final homogenization to the liquid phase (Th) and decrepitation (Td) temperatures. 
Table 2

$\delta^{18} \mathrm{O}$ and $\delta^{13} \mathrm{C}$ values of ankerite and calcite samples.

\begin{tabular}{|c|c|c|c|c|c|c|c|c|}
\hline Sample & Type & $\delta^{18} \mathrm{OCO}_{2}$ & $\delta^{13} \mathrm{C} \mathrm{CO}_{2}$ & $\mathrm{a} \mathrm{CO}_{2}$-carbonate & Correction ${ }^{18} \mathrm{O}$ & Correction ${ }^{13} \mathrm{C}$ & $\delta^{18} \mathrm{O}$ & $\delta^{13} \mathrm{C}$ \\
\hline LS 1 & Ankerite & 24.495 & -12.629 & 1.01050 & 0.10 & 0.05 & 13.9 & -12.6 \\
\hline SEM 33 & Ankerite & 24.708 & -13.434 & 1.01050 & 0.10 & 0.05 & 14.2 & -13.4 \\
\hline SEM 43 & Ankerite & 25.297 & -13.654 & 1.01050 & 0.10 & 0.05 & 14.7 & -13.6 \\
\hline $15-17681$ & Calcite & 22.913 & -9.595 & 1.00936 & 0.32 & 0.05 & 13.7 & -9.5 \\
\hline $15-17675$ & Calcite & 31.698 & -9.612 & 1.00936 & 0.32 & 0.05 & 22.5 & -9.6 \\
\hline $87-14132$ & Calcite & 23.107 & -9.898 & 1.00936 & 0.32 & 0.05 & 13.9 & -9.8 \\
\hline $15-17683$ & Calcite & 22.800 & -9.675 & 1.00936 & 0.32 & 0.05 & 13.6 & -9.6 \\
\hline SEM 62 & Calcite & 23.560 & -12.573 & 1.00936 & 0.32 & 0.05 & 14.4 & -12.5 \\
\hline
\end{tabular}

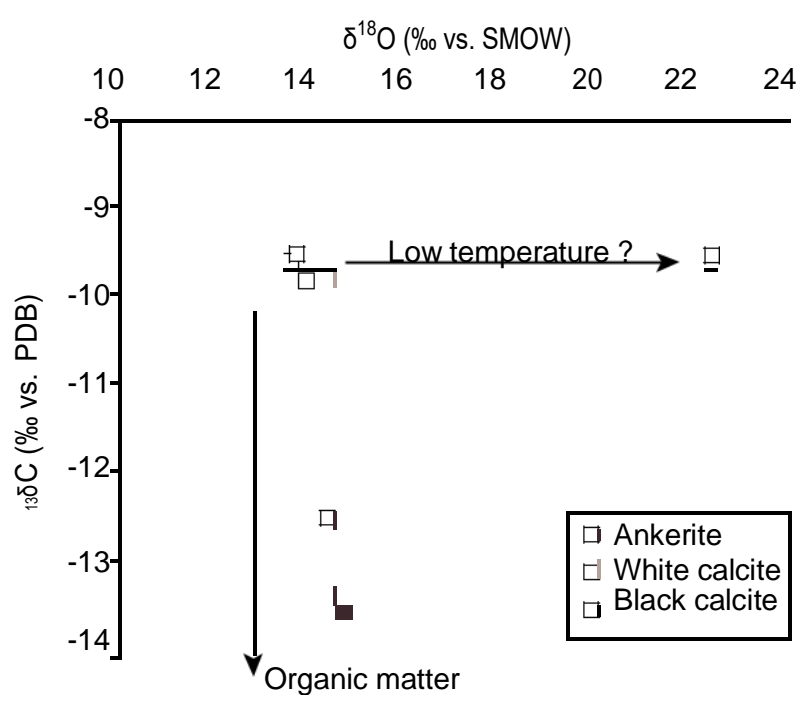

Fig. 9. $\delta^{18} \mathrm{O}\left(\%\right.$ vs. SMOW) versus $\delta^{13} \mathrm{C}(\%$ vs. PDB) diagram with ankerite and calcite isotopic values plotted.

event (Chauris et al., 1985, Pochon et al., 2017) and mainly consists of irregular grains with sizes ranging from 10 to $80 \mu \mathrm{m}$ found within the external preserved shape of its parent mineral (Fig. 10e).

Rutile is frequently encompassed by arsenopyrite (Figs. 5e and 10f) and belongs to the early stage of the paragenetic sequence (Fig. 6). It incorporated large amounts of $\mathrm{Sb}$ (mean value of $111 \mathrm{ppm}$ ) during its crystallization. The fluids responsible for its precipitation were also enriched in $\mathrm{Sb}$ according to Pochon et al. (2017). Consequently, the dating of some inferred magmatic apatite and hydrothermal rutile, found in textural equilibrium, may give constraints about the timing of the hydrothermal event associated with the $\mathrm{Sb}$ mineralization.

Apatite $\mathrm{U}-\mathrm{Pb}$ results obtained are reported in a Tera-Wasserburg diagrams (Fig. 11) and analytical data are given in the Appendix A.8. In the diagram, the red dashed-line represents the unforced discordia whereas the black line represents the discordia calculated with an in-itial common $\mathrm{Pb}$ value forced to a ${ }^{207} \mathrm{~Pb} /{ }^{206} \mathrm{~Pb}$ value of 0.860 calculated following the $\mathrm{Pb}$ evolution model of Stacey and Kramers (1975) for an age of $360 \mathrm{Ma}$, representing the age of mafic magmatism in the area (Pochon et al., 2016b). The unforced ${ }^{207} \mathrm{~Pb} /{ }^{206} \mathrm{~Pb}$ value is in agreement with the lead isotopes ratio $\left({ }^{207} \mathrm{~Pb} /{ }^{206} \mathrm{~Pb}=\right.$ $0.860495)$ measured by Marcoux (1987) on berthierite from the Le Semnon mine.

Data obtained from apatite of the dolerite dyke are discordant with a relatively high proportion of common $\mathrm{Pb}$ ranging from 0.38 to 0.77 (Appendix A.8) and form a cluster with the ${ }^{207} \mathrm{~Pb} /{ }^{206} \mathrm{~Pb}$ values around 0.48 . These data define a lower intercept date of $358 \pm 24 \mathrm{Ma}(\mathrm{MSWD}=1.9)$ with a ${ }^{207} \mathrm{~Pb} /{ }^{206} \mathrm{~Pb}$ initial value of 0.865 (Fig. 12). If the discordia is forced to a value of 0.860 , we obtain a similar date of $357 \pm 17$ Ma $(M S W D=1.9)$. The weighted average ${ }^{207} \mathrm{~Pb}$-corrected date (calculated using Stacey and Kramers (1975) terrestrial Pb evo-lution model) are equivalent within error at 358.5 $\pm 7.1 \mathrm{Ma}(\mathrm{MSWD}=1.6)$. Unfortunately, the $\mathrm{U}-\mathrm{Pb}$ data obtained on rutile are of poor quality and extremely discordant with ${ }^{207} \mathrm{~Pb} /{ }^{206} \mathrm{~Pb}$ values close to the value of common $\mathrm{Pb}$, ranging from 0.78 to 0.87 (Appendix A.8) and therefore cannot yield a meaningful date. Although the ${ }^{207} \mathrm{~Pb} /{ }^{206} \mathrm{~Pb}$ initial value is identical to apatite $(\sim 0.865)$, this value probably re-flects an assimilation of common $\mathrm{Pb}$ from the ilmenite-hematite as-semblage during its breakdown into rutile.

4.4.2. ${ }^{39} \mathrm{Ar}-{ }^{40} \mathrm{Ar}$ dating

Illite ${ }^{40} \mathrm{Ar} /{ }^{39} \mathrm{Ar}$ duplicated experiments from quartz-carbonates-stibnite vein are shown in Fig. 12. Illite age spectra from edge of the mineralized vein (SEMJB.1 \& 2) display disturbed saddle-shaped age spectra with no plateau date which probably express mixing of two components as a result of partial recrystallization (Cheilletz et al., 1999; Alexandrov et al., 2002; Castonguay et al., 2007; Tartèse et al., 2011; Tremblay et al., 2011) of a primary component during a subsequent hydrothermal disturbing event. According to interpretation proposed by Alexandrov et al. (2002), saddle sidewalls apparent ages in the low and high temperature steps would yield a minimum estimate of the primary component age, in this case at least ca. $358.0 \pm 1.4 \mathrm{Ma}$ according to low temperature apparent ages of experiment 2. Extent of disturbance and overlapping of two component degassings are such that observed age spectrum SEMJB.2 derogate from model proposed by Alexandrov et al. (2002) as high temperature saddle sidewall is no more express. Nevertheless, increase of apparent age at fusion for experiment SEMJB.1 suggests that above viewed model is applicable. Furthermore, this ca. $358 \mathrm{Ma}$ age is in agreement with $\mathrm{U}-\mathrm{Pb}$ apatite age from the hydrothermally altered dolerite dyke of the Le Semnon mine. Referring back to the model proposed by Alexandrov et al. (2002) and according to the degree of separation achieved during degassing experiment, the apparent ages of the base of the saddles, with concordant plateau and pseudo plateau ages at $339.0 \pm 0.9 \mathrm{Ma}$ and $338.7 \pm 1.0 \mathrm{Ma}$, for ex-periments 1 and 2, respectively, are maximum age estimates of the secondary component, and thus related subsequent disturbing event.

Duplicated experiments performed on illite grains (SEMAP.1 \& 2) collected at the contact of massive stibnite, with a pseudo-plateau age at 335.5 $\pm 0.9 \mathrm{Ma}$ in the high temperature steps (exp.1), lower than previous estimates (SEMJB) suggest that age determination of the sec-ondary disturbing event will unfortunately remain a pious wish as it is probably younger than ca. 335 Ma.

\section{Interpretation and discussion}

\subsection{Sb evolution in the hydrothermal system: record of a progressive cooling}

There is abundant evidence that $\mathrm{Sb}$ was present and relatively en-riched in the fluids from the early to the last stage in the paragenetic evolution. In the early stage, rutile resulting from the hydrothermal 

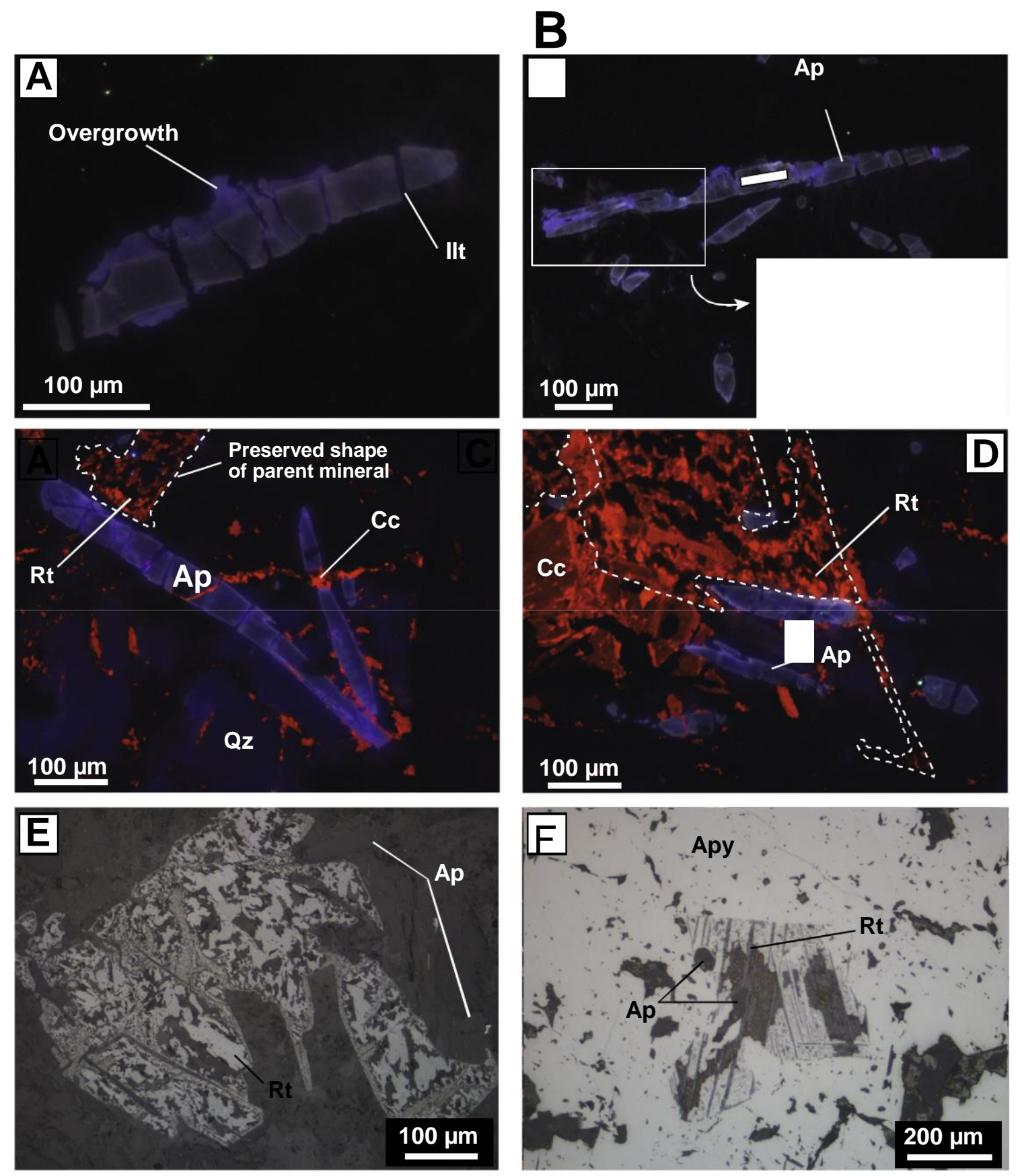

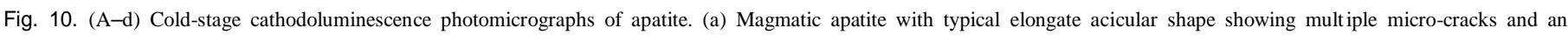

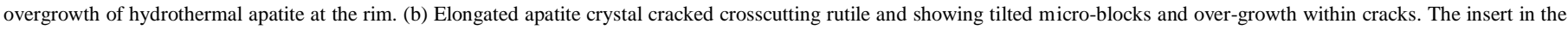

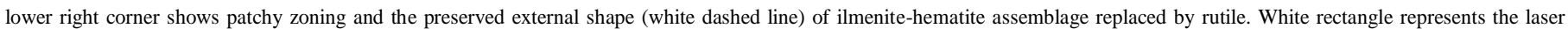

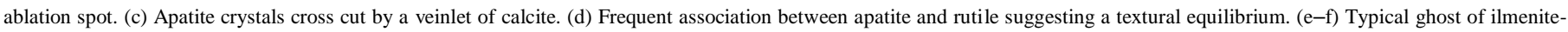

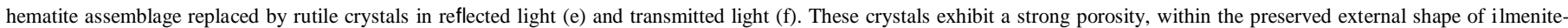
hematite assemblage, filled by carbonates and illite.

breakdown of ilmenite-titanohematite mineral assemblage has rela-tively high concentration of Sb ( 100 ppm) in its crystal lattice (Pochon et al., 2017). Although the crystallization temperature of rutile is not known, it is assumed that this stage was relatively hot $\left(>400{ }^{\circ} \mathrm{C}\right.$ ?) in so far as the mineral replacement seems to be a coupled hydrothermal alteration. Formed in the following stage, disseminated arsenopyrite displays an average content of $0.37 \%$ of $\mathrm{Sb}$ (Appendix A.5) and contains numerous inclusions of $\mathrm{Sb}-$ sulfosalts (e.g. tetrahedrite and chalcostibite), like the associated pyrite (Fig. 5e). Using the arsenopyrite geothermometer of Kretschmar and Scott (1976) modified by Sharp et al. (1985), the temperature of crystallization is estimated at about $360{ }^{\circ} \mathrm{C}$ (Appendix A.6). Finally, the last stage consists of the main $\mathrm{Sb}$ mineralization with the precipitation of native antimony and native gold followed by berthierite and by final stibnite (Figs. 5b, d, g, h and 6).

The major factors controlling antimony solubility are temperature, oxygen fugacity ( $\mathrm{fO}_{2}$ ), $\mathrm{pH}$ and the total sulfur activity (Williams-Jones and Normand, 1997). Within a hydrothermal solution, it is known that 


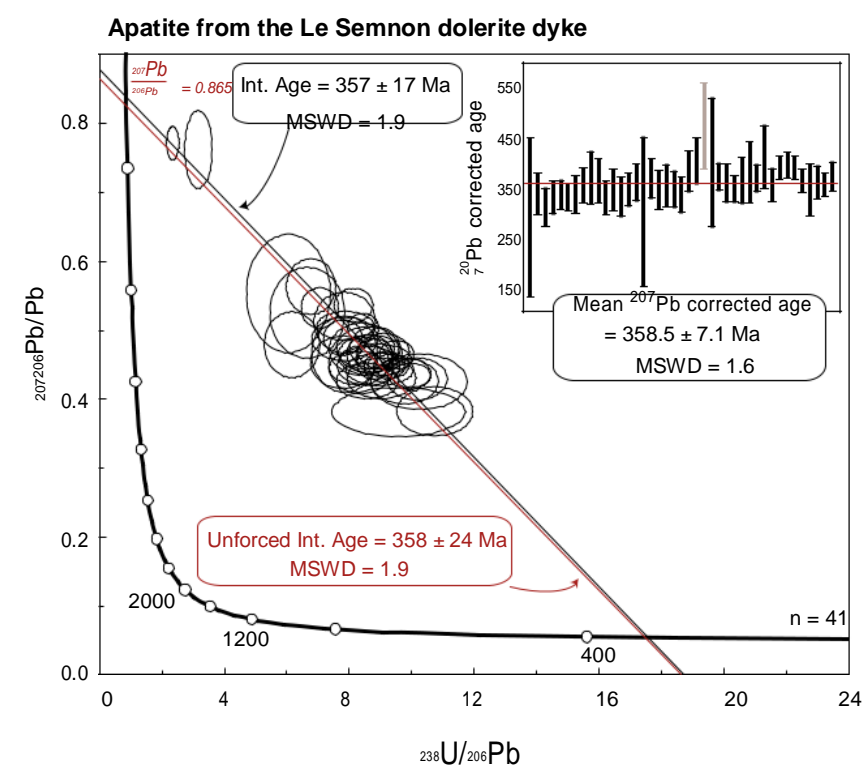

Fig. 11. Tera-Wasserburg concordia diagram with the corresponding mean $207 \mathrm{~Pb}-$ corrected age for the apatite from the dolerite dyke of the Le Semnon mine. The red dashed-line represents the unforced discordia and the black line represents the forced discordia with $207 \mathrm{~Pb} / 206 \mathrm{~Pb}$ value of 0.860 calculated following the $\mathrm{Pb}$ evolution model of Stacey and Kramers (1975) for an age of 360 Ma. Errors are provided at $2 \sigma$ level. (For interpretation of the references to color in this figure legend, the reader is referred to the web version of this article.)

antimony is mainly transported as $\mathrm{Sb}(\mathrm{OH}) 3^{0}$ (Wood et al., 1987; Shikina and Zotov, 1991), $\mathrm{HSb}_{2} \mathrm{Sb}_{4}^{-}$(which predominates at intermediate $\mathrm{pH}$, Krupp, 1988; Spycher and Reed, 1989) and $\mathrm{Sb}_{2} \mathrm{~S}_{2}(\mathrm{OH}) 2^{0}$ (which is im-portant at low $\mathrm{pH}$, Krupp, 1988). In a solution with a neutral $\mathrm{pH}$, the predominant $\mathrm{Sb}$ species are $\mathrm{Sb}(\mathrm{OH}) 3^{0}$, except at intermediate $\mathrm{fO}_{2}$ where $\mathrm{Sb}_{2} \mathrm{~S}_{2}(\mathrm{OH}){ }_{2}{ }^{0}$ and $\mathrm{HSb} 2 \mathrm{Sb}^{-} 4$ are predominant in the $180-280{ }^{\circ} \mathrm{C}$ tempera-ture range and below 180 ${ }^{\circ} \mathrm{C}$, respectively (Williams-Jones and Normand, 1997). A decrease in temperature is the simplest way to explain the precipitation of native antimony followed by the deposition of berthierite and by later stibnite (Fig. 13) from the last stage (e.g. Barton, 1971; Barton and Skinner, 1979; Williams-Jones and Normand, 1997). Thus, the multistage paragenetic evolution can reflect a progressive cooling of the hydrothermal system from early $\mathrm{Sb}$-rich ru-tile to late stibnite rather than contrasted mineralizing events devel-oped at different times. This single mineralizing event is consistent with the early Sb saturation of the fluid and by the compositionally single potassic (Appendix A.4) hydrothermal assemblage during the para-genetic evolution.

\subsection{Nature and fluid evolution of the hydrothermal system}

Except for one sample with a high $\delta^{18} \mathrm{O}$ value likely recording lowtemperature formation, the $\delta^{18} \mathrm{O}$ values of carbonates are homogeneous (Table 2, Fig. 10). This result suggests that the conditions of pre-cipitation $\left(\delta^{18} \mathrm{O}\right.$ value of fluid, fluid temperature and fluid/rock ratio) were similar for calcite and ankerite. In contrast, the $\delta^{13} \mathrm{C}$ values are more scattered and tend toward organic matter reservoir (Fig. 10). This suggests an interaction with the country rocks, probably the lower Ordovician slates which are rich in organic matter (Herrouin et al., 1990). Oxygen isotope signatures likely result from the equilibration between the fluids and the local crustal rocks, leading to homogeneous, unspecific crustal signatures.

Fluid inclusions analyses suggest the presence of two types of fluids: (1) hot aqueous-carbonic fluids (Lc-w and Lw-c type) with minor $\mathrm{N}_{2}$ and $\mathrm{CH}_{4}$ and relatively low salinity $(\sim 6 \mathrm{wt} \%$ eq. $\mathrm{NaCl}),(2)$ cold aqueous fluids. It is difficult to establish a chronology for the FIs entrapment because crack-seal evidenced in quartz records fluid pressure cycling associated with repeated crack events and because both types of FIs are found inside a single quartz sample. However, the lower volatile phase density, the lower salinity, and the lower $\mathrm{CO}_{2}$ proportion correlated with the increase of $\mathrm{H}_{2} \mathrm{O} \mathrm{Lw}-\mathrm{c}$ inclusions seems to show that these fluids could come from the dilution of fluids trapped in Lc-w inclusions. This dilution can be illustrated by the evolution trend showing fluids trapped at relatively high temperature conditions which evolved toward fluids trapped at lower temperature (Fig. 8d). The two types of fluids are si-milar to fluids encountered in many orogenic gold deposits from the West-European Variscan belt (Clayton et al., 1990; Couto et al., 1990; Ortega and Vindel, 1995; Ortega et al., 1996; Essarraj et al., 2001; Boiron et al., 2003) and these fluids are characteristic of crustal fluids probably derived from metamorphic origin and mixing with meteoric fluids.

Fig. 14 illustrates the possible P-T conditions of fluids entrapment of the Le Semnon mineralization. In order to constrain the P-T ranges of

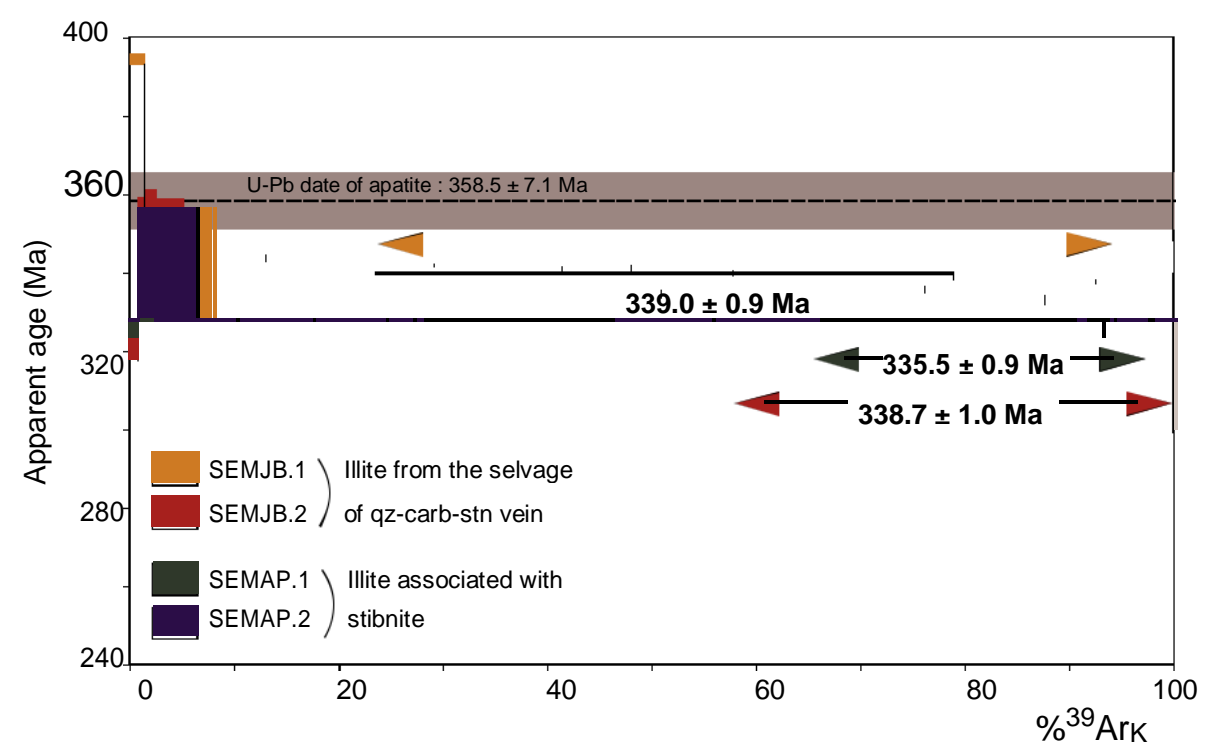

Fig. 12. ${ }^{40} \mathrm{Ar} /{ }^{39} \mathrm{Ar}$ age spectra ( $1 \sigma$ relative uncertainties) of illite samples from quartz-carbonates-stibnite veins. 


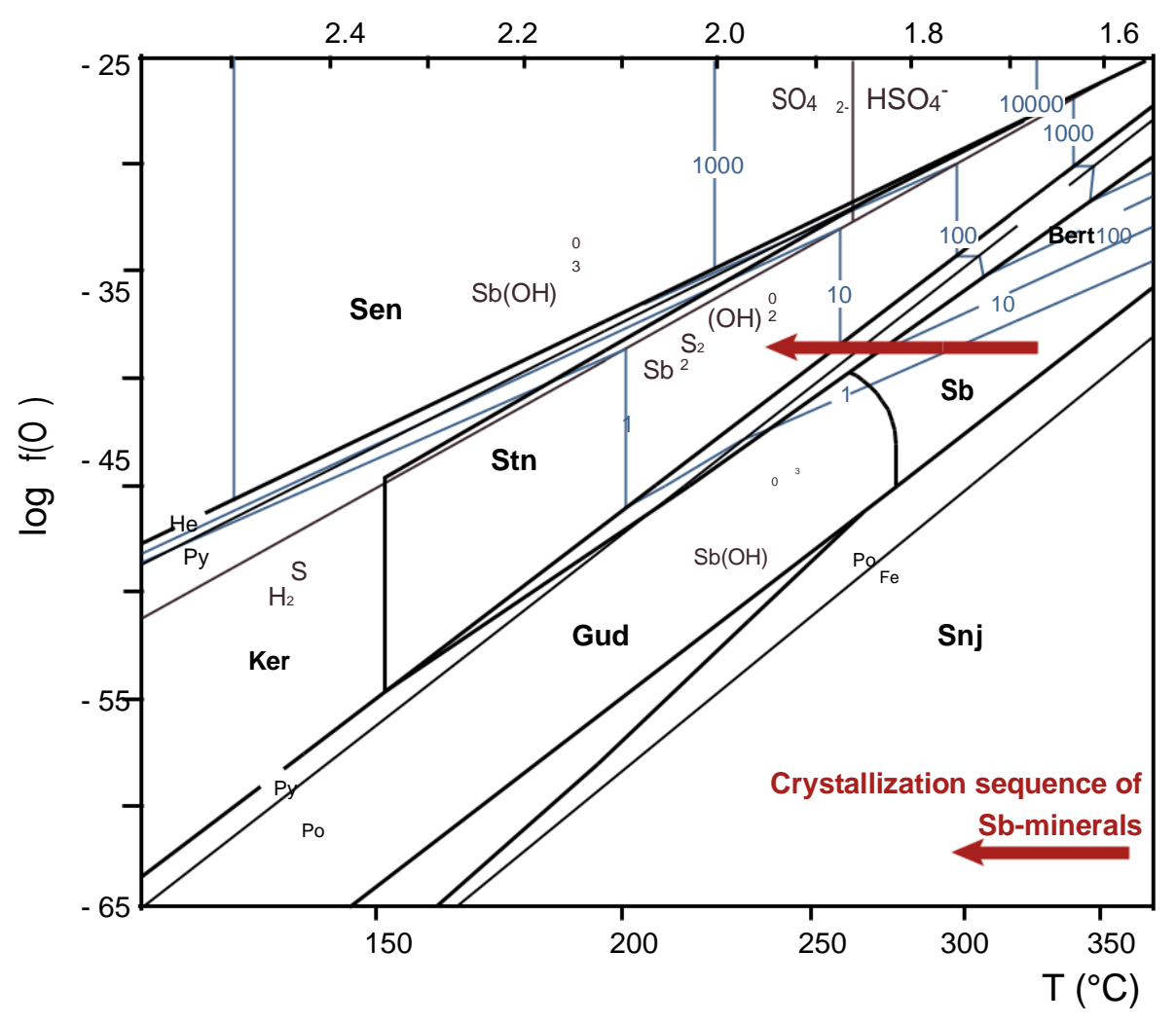

Fig. 13. $\mathrm{Log}$ fO2 $-1000 / \mathrm{T}(\mathrm{K})$ diagram at neutral $\mathrm{pH}$ and $\Sigma$ as $=0.01$, showing stability relationships in the system Fe-Sb-S-O and contours of antimony mineral solubility in ppm in light blue dashed lines (after Williams-Jones and Normand, 1997). The heavy dashed grey lines show the predominance

boundaries of species in the system H-S-O. Bert $=$ berthierite, gud $=$ gudmundite,$\quad$ hem $=$ hematite, $\mathrm{po}=$ pyrrhotite,$\quad \mathrm{py}=$ pyrite,$\quad \mathrm{sb}=$ native antimony, $\quad$ sen = senarmontite, $\quad s n j=$ seinajokite $\operatorname{stn}=$ stibnite. Mineral abbreviations from Whitney and Evans (2010). (For interpretation of the references to color in this figure legend, the reader is referred to the web version of this article.)

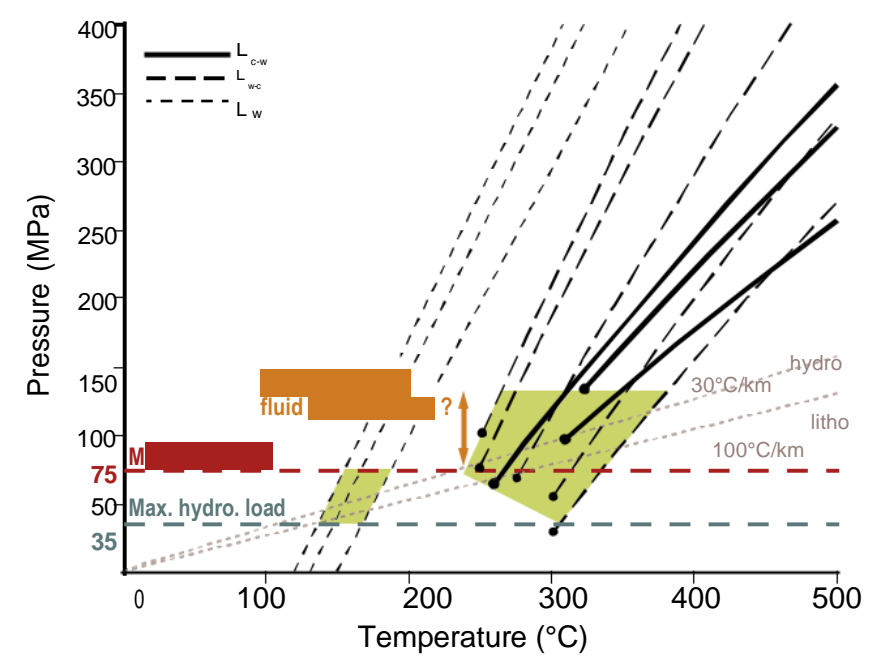

Fig. 14. Estimated P-T conditions for the formation of the Sb-Au extensional veins from calculated isochores. The most likely P-T fields are represented by color shades. See text for more details about estimation of the maximum li-thostatic load (max. litho. load) and hydrostatic load (max. hydro. load).

entrapment, the maximum lithostatic and hydrostatic loads were cal-culated from the tectonic and stratigraphic considerations known in the area. Central Brittany never experienced crustal thickening during the Variscan orogeny (Gumiaux et al., 2004a) and sedimentation stopped at the end of the Devonian (Ballèvre et al., 2014; Herrouin et al., 1990), except in Carboniferous basins localized along major shear zones (Chateaulin Basin and East of La Lucette in Fig. 1). Consequently, the stratigraphic sequence in the Le Semnon area is considered as continuous series from lower Ordovician to Upper Devonian and has a maximum thickness of $2.5 \mathrm{~km}$ (Herrouin et al., 1990). Considering reasonable free water column $(1 \mathrm{~km})$, this depth correspond to a max-imum pressure of $75 \mathrm{MPa}$ under a lithostatic regime and $35 \mathrm{MPa}$ under a hydrostatic regime (Fig. 14). Three aqueous-carbonic isochores have a minimum pressure of entrapment higher than this lithostatic load. The highest pressure recorded by aqueous-carbonic isochores corresponds to a $5 \mathrm{~km}$ depth under lithostatic regime. Record of entrapment pressure higher than the lithostatic pressure suggests a supralithostatic fluid overpressure consistent with flat extensional veins associated with crack-seal mechanism (Figs. 3a-d and 4b). Considering that the max-imum lithostatic pressure (i.e. $75 \mathrm{MPa}$ ) is the minimum necessary condition to generate sub-horizontal extensional veins, almost all the aqueous-carbonic fluids are interpreted to have a minimum entrapment temperature ranging between 240 and $330{ }^{\circ} \mathrm{C}$ (Fig. 14). This range of temperature is consistent with the temperature decrease highlighted by the crystallization of native gold and $\mathrm{Sb}$ followed by berthierite and stibnite (Fig. 13), observed inside extensional veins. Consequently, aqueous FIs, interpreted as meteoric fluids, were likely trapped under hydrostatic regime in a minimum temperature range comprised be-tween 130 and $160^{\circ} \mathrm{C}$ (Fig. 14).

Considering the shallow depth emplacement of the Le Semnon de-posit (2.5 km maximum), attached temperatures would require a rather abnormal geothermal gradient (around $100{ }^{\circ} \mathrm{C} / \mathrm{km}$ in a lithostatic re-gime). Such elevated geothermal gradient is inconsistent with the low-grade regional metamorphism and rather involves a thermal source in disequilibrium, such as magmatic component or heat advected by fluids. However, geothermal gradient $\left(30{ }^{\circ} \mathrm{C} / \mathrm{km}\right.$ in hydrostatic regime) appears ordinary for meteoric aqueous fluids trapped in hydrostatic regime, likely suggesting that these fluids are disconnected from the high thermal event related to $\mathrm{Sb}-\mathrm{Au}$ mineralization. 
5.3. Formation of Sb-Au vein systems: evidence for fluid overpressure and "small-scale fault-valve mechanism"

As the Le Semnon veins system includes flat veins with no dilata-tional jogs geometries, nor implosive hydraulic breccias, the suction pump mechanism proposed by Sibson (1987) for shallow epithermal mineralization does not fit with our observations. Other mechanical models could explain the Le Semnon veins pattern. First, Gaboury and Daigneault (2000) proposed a self-equilibrating mechanical model to explain flat-lying hydrothermal veins associated with vertical magmatic dykes. However, our case study is lacking sub-horizontal inherited fractures/anisotropies before veining, and the stress regime is locally compressive. Hence, specific conditions for selfequilibrating me-chanism are not fulfilled. Secondly, Cobbold and Rodigues (2007) proposed that fluid seepage forces are able to generate flat-lying hydrofractures in sedimentary basins (the so-called "beef", i.e. bedding-par-allel fibrous veins). Veins distribution along mafic dykes, crack-seal internal textures together with the non-basinal nature of hydrothermal fluids, led us to exclude this "beef" mechanism. Finally, flat-lying veins and associated faultfill veins may easily be interpreted as the con-sequence of a fault-valve behavior mechanism.

Fault-valve behavior is known in fault-systems that are unfavorably oriented for a typical frictional reactivation (Boullier and Robert, 1992; Cox, 1995; Henderson and MacCaig, 1996; Robert et al., 1995; Sibson, 2001; Sibson et al., 1988), although this process has been described for fault systems favorably oriented to undergo fault reactivation (Faleiros et al., 2007; Kolb et al., 2004; Nguyen et al., 1998). Many orogenic gold deposits in compressive tectonic regime formed through this me-chanism in high fluid flux regimes associated with high-angle reverse faults and opening subhorizontal extensional fractures (e.g. Boullier and Robert, 1992; Henderson and MacCaig, 1996; Robert et al., 1995; Sibson et al., 1988). Sub-horizontal extensional veins resulting from hydraulic fracturing are formed within dilatant zones during pre-failure stages and indicate that fluid pressure reached or exceeded the minimum principal stress ( $\sigma 3)$ (i.e. lithostatic load, Cox et al., 1991; Robert et al., 1995; Sibson et al., 1988). In the fault zone, (supra)-li-thostatic fluid pressures trigger shear failure along the reactivated fault, promoting permeability and a substantial drop in fluid pressure toward hydrostatic values. During the immediate post-failure stage, fluids mi-grate into the opened fault from the dilatant zones forming fault-fill veins and sealing fractures (Sibson et al., 1988). Hydrothermal sealing decreases the fault-permeability and allows for the repetition of cycle of fluid pressure from (supra)-lithostatic to hydrostatic pressure, the so-called fault-valve action by fluid-overpressure cycling (Sibson et al., 1988).

In the Le Semnon Sb-Au deposit, fault-fill and associated extensional veins are preferentially localized at the contact between the dolerite dyke and the lower Ordovician slates (Fig. 4b) suggesting a first-order rheological control for the localization of the Sb-Au ore deposition. Slates acted as an impermeable barrier and the borders of the dolerite dyke may have acted as a plumbing system for the fluids. The scarcity of veins away from the contact could indicate that (1) the interface be-tween the slates and dolerite dyke constituted a discontinuity enhan-cing permeability and promoting upward fluid flow and fluid pressure increase, and/or (2) the rheological contrast between the competent dyke and the incompetent slates promoted fracturing at the interface. The vein geometry (Fig. 4) argue for sub-horizontal maximum principal stress $(\sigma 1)$ and sub-vertical minimum principal stress $(\sigma \mathrm{v}$ $=\sigma 3$ ), typical for a compressional regime. Fault-fill veins have an angle of about $60^{\circ}$ compared to $\sigma 1$, indicating that reverse faults are misoriented (i.e. an optimum angle between $\sigma 1$ and a fault should be around $30^{\circ}$ for a ty-pical coefficient of rock friction, Sibson, 1985) and were probably ac-tivated at high fluid pressure conditions (Sibson et al., 1988; Cox et al.,
2001; Micklethwaite, 2008). This may suggest either a reactivation of preexisting misoriented discontinuity or a continuous reactivation of an initially well-oriented thrust that steepens progressively as the wall rocks absorb some of the regional shortening strain (Sibson et al., 1988). The latter is the most probable scenario because of the aniso-tropy that exists between the dyke and slates and because the contact accommodated part of the regional strain (e.g. cleavage is more de-veloped at the contact). This contact is extremely misoriented and shows no displacement or slip events along it. Sub-horizontal exten-sional veins with elongate blocky and fibrous growth perpendicularly to vein wall-rock (Figs. 3d, 4b, c and 5b) suggest, at least locally and in-termittently, a lithostatic to supralithostatic fluid pressure. Further-more, crack-seal textures in the extensional veins (Figs. 3d and 5a) indicate fluid pressure fluctuations associated with repeated crack events (Ramsay, 1980; Cox, 1987, 1995; Cox et al., 1991). Furthermore, many lines of evidence have shown that the region is essentially af-fected by strike-slip tectonics (Gumiaux et al., 2004a) from Late De-vonian to Late Carboniferous times. We suggest that overpressure fluids in the Le Semnon area was responsible for a local switch between re-gional $\sigma 3$ and $\sigma 2$ (i.e. local $\sigma 3$ becomes $\sigma \mathrm{v})$. This mechanism of stress permutation is well identified in magmatic overpressure systems (Vigneresse et al., 1999).

The veins geometry of the Le Semnon deposit, described above, is very similar to many natural case studies of gold orogenic deposits associated with high-angle reverse faults (e.g. Boullier and Robert, 1992; Henderson and MacCaig, 1996; Robert et al., 1995; Sibson et al., 1988) and seems to fulfill all of the expected conditions for a fault-valve mechanism. However, the small-scale of the extensional and fault-fill veins from the Le Semnon deposit are hardly comparable with the conditions prevailing for crustal-scale Archean shear zone-hosted gold deposits (e.g. Sigma mine, Val d'or, Quebec, Robert and Brown, 1986). Indeed, the formation of the Le Semnon Sb-Au deposit occurred close to the surface at a predominant hydrostatic regime (see below), and be-cause dolerite dyke injection into impermeable slates locally breached the impermeable barrier constituted by the slates, fluid overpressure may have occurred. The schematic model of the "small-scale fault valve mechanism" is illustrated in Fig. 15. Magma injection into impermeable slates created a newly-formed and local impermeable barrier around the dolerite dyke and allowed for upward fluid flow at the contact (Fig. 15a). However, fluids were restricted to the breached contact between dyke and slates, and fluid pressure substantially increased because fluids cannot have passed through the local impermeable barrier. Fluid pressure reached (supra)lithostatic values and fluid-filled dilatant cracks (i.e. extensional veins) formed as illustrated by the shift to the left of Mohr circle (Fig. 15b). In order to tend to stability, fluid overpressure was always followed by rock failure or by faults re-activation (Fig. 15a). In this case study, it is believed that fault rupture induced micro-earthquake, breaking through the local impermeable barrier and allowing for a fluid discharge along the fault (Fig. 15b). Sealing of the fault by veins acted as a plug and promoted a re-accu-mulation of fluids leading to a new fluid overpressure cycle up to the end of the hydrothermal system life.

\subsection{Timing of $\mathrm{Sb}-\mathrm{Au}$ mineralization}

The paragenetic sequence of Sb-Au mineralization of the Le Semnon mine (Fig. 6) seems to reveal a three-stage evolution. The early stage, described in details in Pochon et al. (2017), is best expressed in dolerite dykes and probably resulted from a hot hydrothermal and pervasive alteration because it is characterized by the complete breakdown of magmatic ilmenitehematite assemblage into rutile, and the destruction of calcic plagioclase and clinopyroxene. This stage was followed by an As-Fe-Sb-Au pervasive hydrothermal alteration characterized by 

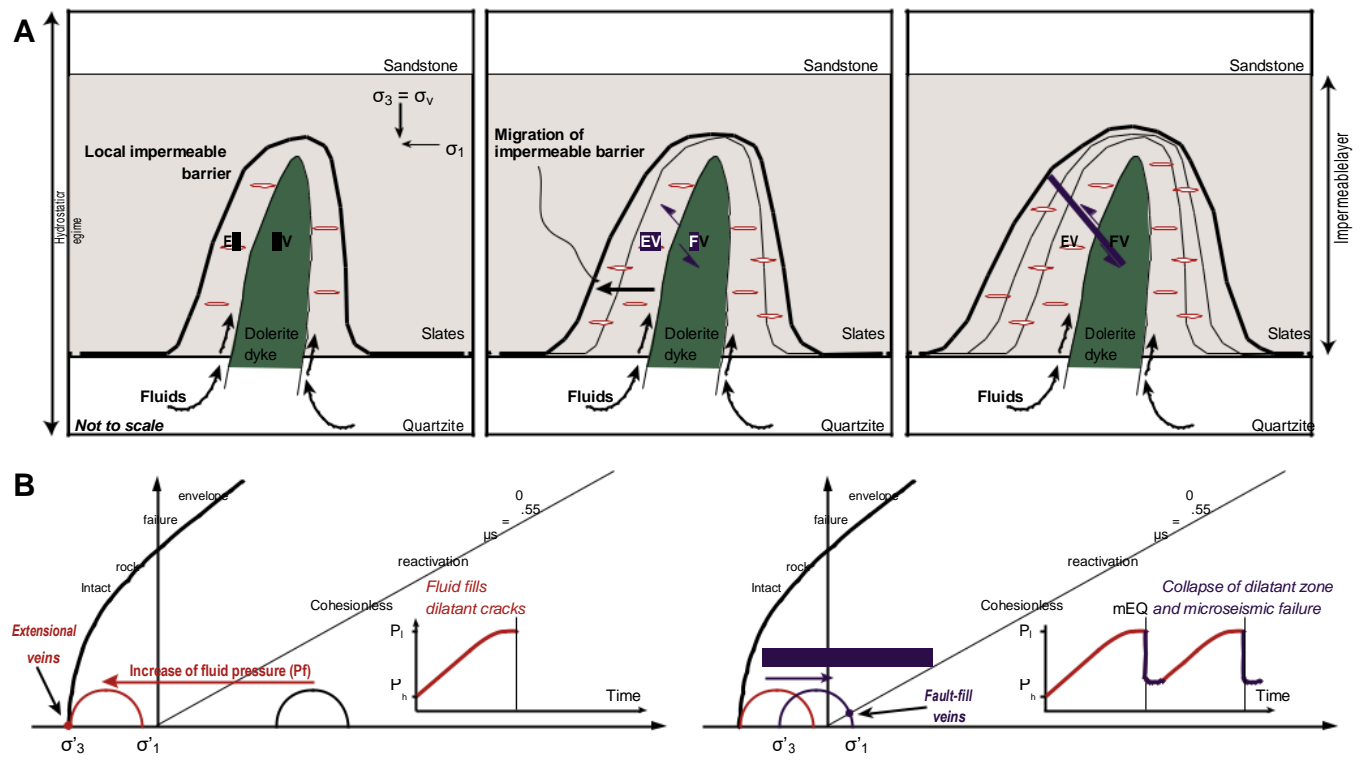

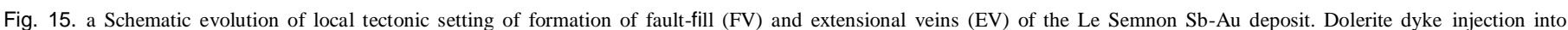

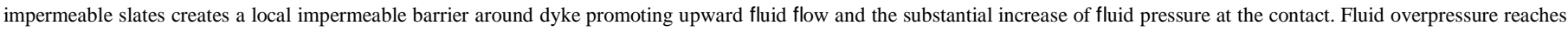

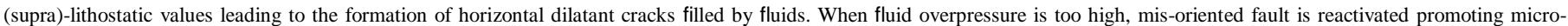

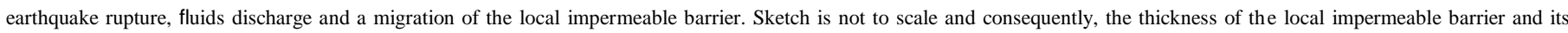

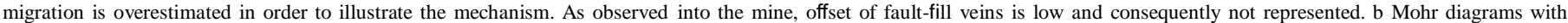

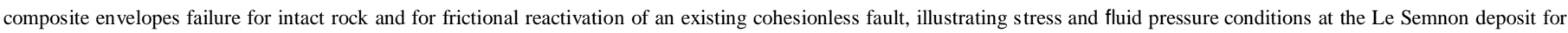

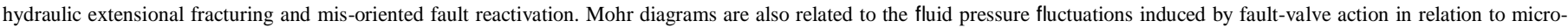
earthquake rupturing cycle (mEQ). Extensional veins occur during pre-rupture dilatation stage and fault-fill veins occur just after the rupture.

arsenopyrite dissemination and by the main $\mathrm{Sb}-\mathrm{Fe}$ mineralization event characterized by hydraulic fracturing at the contact between the do-lerite and slates.

$\mathrm{U}-\mathrm{Pb}$ analyses of apatite from the dolerite dyke of Le Semnon de-posit provide a weighted average ${ }^{207} \mathrm{~Pb}$-corrected date of $358.5 \pm 7.1 \mathrm{Ma}$ (MSWD $=1.6$ ), consistent with the unforced and forced lower intercept dates of $358 \pm$ $24 \mathrm{Ma}(\mathrm{MSWD}=1.9)$ and $357 \pm 17 \mathrm{Ma}(\mathrm{MSWD}=1.9)$, respectively (Fig. 11). Although un-certainty is relatively high, this date is quite similar to the emplacement age of the regional mafic magmatism in the Armorican Massif, dated at ca. $360 \mathrm{Ma}$ (Pochon et al., 2016b). Furthermore, this date is also similar to the age of another dolerite dyke $(363.3 \pm 3.1 \mathrm{Ma}, \mathrm{N}=22, \mathrm{MSWD}=$ 2.6; Pochon et al., 2016b), belonging to the same dyke swarm and located 4 $\mathrm{km}$ to the east (Fig. 2), suggesting that all the dykes from this swarm were emplaced contemporaneously. However, other do-lerite dykes dated throughout the Armorican were not affected by hy-drothermal alteration although they yielded similar ages (Pochon et al., 2016b). In the Le Semnon case study, the dolerite dyke is deeply altered and therefore its texture and mineralogy was modified during the pervasive and mineralizing hydrothermal event. Magmatic apatite seems to be in textural equilibrium with hydrothermal rutile that re-placed all magmatic Fe-Ti oxides (Fig. 10b-e) and formed during the early stage of the paragenetic evolution (Fig. 6). Furthermore, the patchy zoning (Fig. 10b and d), the zoning around the rim and micro-cracks of apatite (Fig. 10a-d), calcite-fill micro-cracks (Fig. 10c and d) and overgrowths around apatite (Fig. 10a) reveal that the apatite lattice was disturbed. Two assumptions can be proposed for the significance of the $\mathrm{U}-\mathrm{Pb}$ apatite date found: (1) either the apatite $\mathrm{U}-\mathrm{Pb}$ chronometer was not sensitive to the two-stage pervasive hydrothermal event (early stage and AsAu stage, Fig. 6), which completely modified the dolerite dyke, and consequently, the U-Pb date would reflect the emplacement age of the dolerite dyke, or (2) the U-Pb chronometer of apatite was reset by pervasive fluids but the high age uncertainties $( \pm 7 \mathrm{Ma})$ pre-clude a clear distinction between the magmatic and hydrothermal events which could actually be coeval. The latter hypothesis is more realistic because it is well known that phosphate minerals, such as apatite or monazite, are very sensitive to crustal fluid circulations on a wide range of temperatures (Budzyń et al., 2011; Harlov et al., 2005, 2007, 2011; Seydoux-Guillaume et al., 2012; Grand'Homme et al., 2016; Ballouard et al., in press) and the interaction with a pervasive hot fluid $\left(360{ }^{\circ} \mathrm{C}\right.$ on arsenopyrite geothermometry) is the most effective way to reset this chronometer (Harlov and Hetherington, 2010; Harlov et al., 2011; Ballouard et al., in press). For these reasons, we believe that the U-Pb date of apatite reflects a hydrothermal event, already enriched in $\mathrm{Sb}$ (Pochon et al., 2017), occurring shortly after the em-placement of the dolerite dyke swarm.

As previously suggested, and despite strongly disturbed age spectra, ${ }^{40} \mathrm{Ar} /{ }^{39} \mathrm{Ar}$ analyses suggest that illite crystallized initially at ca. 358-359 Ma. The two most probable scenarios for the hydrothermal history recorded by illite samples are: (1) a hydrothermal fluid pulse probably younger than ca. $335 \mathrm{Ma}$ which partially reset all the different samples to various degrees, or (2) a more or less continuous fluid flow locally and partially affecting rocks at different times. In the Le Semnon hydrothermal context, we favor the second scenario especially because the veins geometric arrangement (Fig. 4b) indicates a fault-valve be-havior with seismic cycles and the crack-seal textures in extensional veins (Figs. 3d and 5a) indicate fluid pressure fluctuations (e.g. Cox, 1995). Furthermore, several evidences for early Sbbearing phases have been documented. The incorporation of $\mathrm{Sb}$ inside the crystal lattice of hydrothermal rutile $(\sim 100 \mathrm{ppm}$ in average and up to 500 ppm) has 


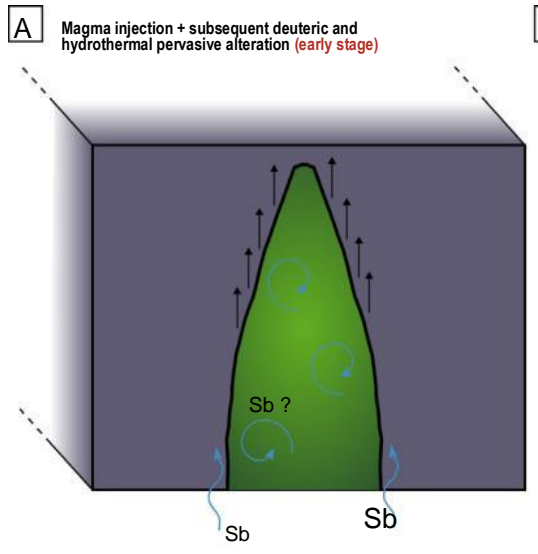

(a.2) Fe-Ti oxides breakdown and apatite recrystallization

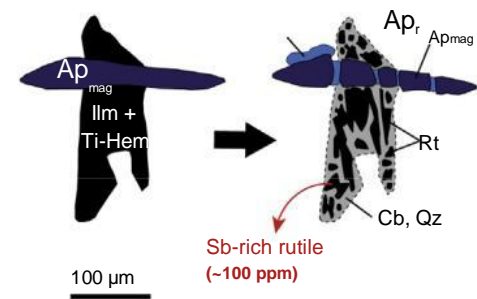

$00 \mu \mathrm{m}$
B. Hydrothermal pervasive alteration As-Fe-Sb-Au stage

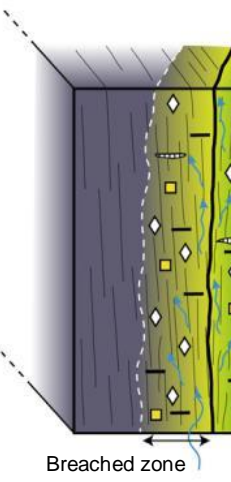

Breached zone

b.2) Arsenopyrite and pyrite growth

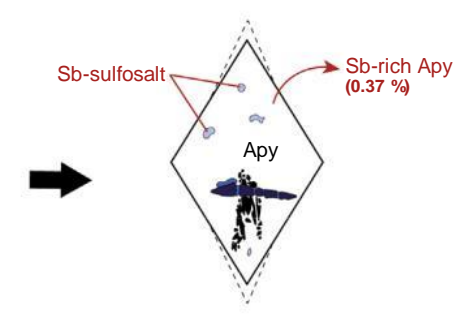

200 بm

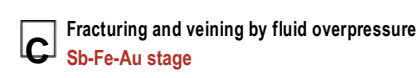

$\mathrm{Sb}-\mathrm{Fe}-\mathrm{Au}$ stage

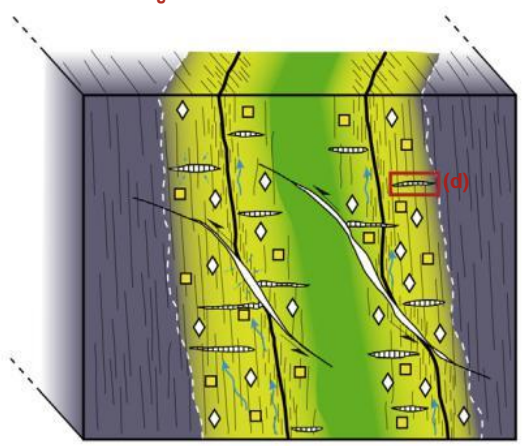

(c.2) Sb-minerals growth in arsenopyrite pressure shadows

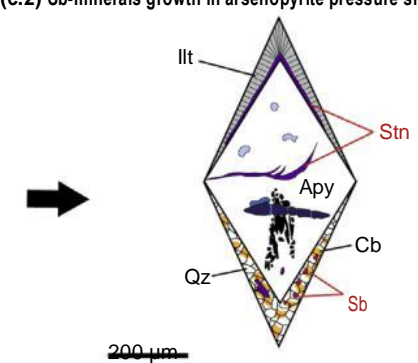

E Sb-minerals evolution during the last Sb-Fe-Au stage

D Incremental evolution of extensional veins

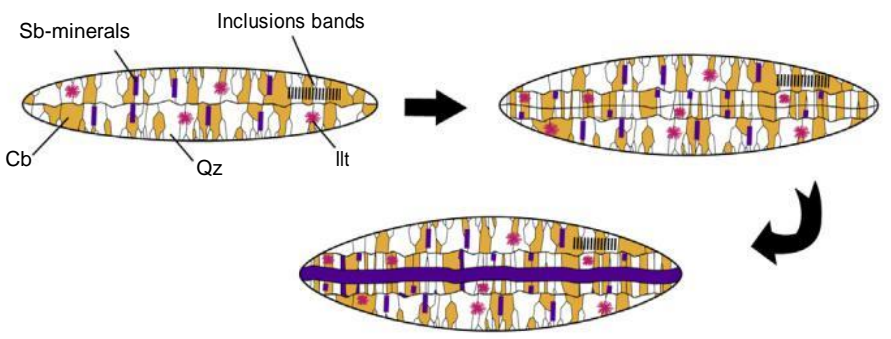

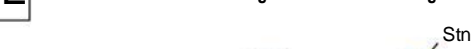
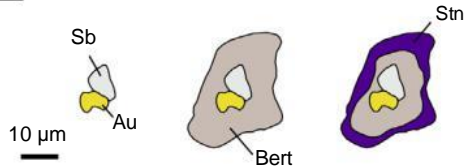

Native

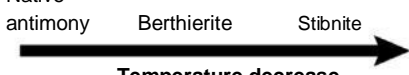

Temperature decrease

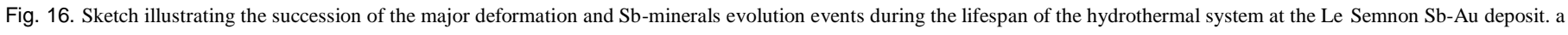

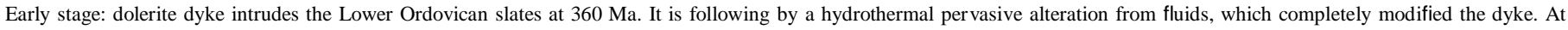

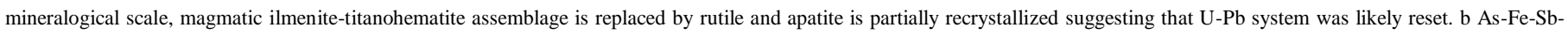

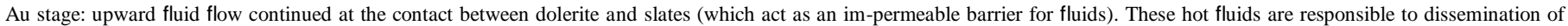

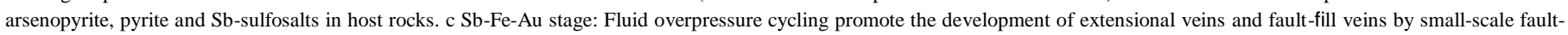

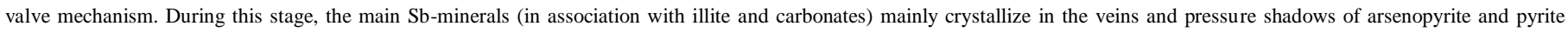

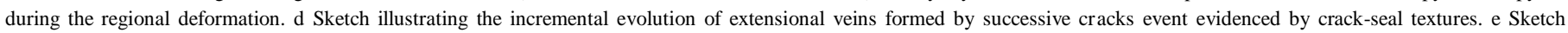
illustrating the evolution of Sb-minerals (native antimony, berthierite and stibnite) by decrease of temperature during this last mineralizing stage.

been demonstrated by Pochon et al. (2017), suggesting that early fluids responsible for the breakdown of the ilmenite-hematite assemblage into rutile was already enriched in Sb. The frequent inclusions of Sb-sulfo-salts (e.g. chalcostibite and tetrahedrite) within arsenopyrite also in-dicate that $\mathrm{Sb}$ was already present before the main $\mathrm{Sb}$ deposition (e.g. berthierite and stibnite). Based on structural, petrological and geo-chronological data, it is reasonable to consider that the paragenetic evolution reflects a continuous Sb-bearing fluid flow with a progressive evolution of its composition marked by a decrease in temperature of ore deposition. Thus, the timing of $\mathrm{Sb}$ ore deposition would be comprised between the early hydrothermal event, coinciding with the emplace-ment age of the dolerite dyke at ca. $360 \mathrm{Ma}$ and the maximum age of alteration at ca. $335 \mathrm{Ma}$. One cannot exclude that this maximum age of recrystallization might reflect a fluid event totally disconnected from the $\mathrm{Sb}$ history, as suggested by the meteoric fluid inclusions trapped in quartz from extensional veins.

\subsection{Toward a genetic model for the Le Semnon Sb-Au deposit}

The emplacement model for the Le Semnon Sb-Au deposit and the continuous evolution of the hydrothermal system are illustrated in Fig. 16. U$\mathrm{Pb}$ and ${ }^{40} \mathrm{Ar} /{ }^{39} \mathrm{Ar}$ results show that Sb-Au mineralization occurred rather early in the Variscan history of Central Brittany and that was probably connected to the dolerite dyke emplacement occur-ring at ca. $360 \mathrm{Ma}$ in the region. As discussed above, the $\mathrm{U}-\mathrm{Pb}$ date obtained on apatite is interpreted as the age of the pervasive alteration 
of the dyke. As this fluid was already enriched in Sb (Pochon et al., 2017), it is proposed that the doleritic magma brought $\mathrm{Sb}$-rich fluids during its ascent, leading to the breakdown of Fe-Ti oxides and the concomitant reset of the magmatic apatite $\mathrm{U}-\mathrm{Pb}$ system (Fig. 16a.1). Antimony-rich fluids may have variable origins, with contributions from the country rocks. Following the dyke emplacement, upward fluid flow continued at the contact with surrounding rocks, which acted as a plumbing system (Fig. 16b), pervasively modifying the chemical com-position of the host rocks leading to the dissemination of $\mathrm{Sb}$-rich ar-senopyrite, pyrite and $\mathrm{Sb}$-sulfosalt. The growth of these minerals seems to have happened contemporaneously with the regional deformation, as recorded by pressure shadows around arsenopyrite and pyrite. Then, as the increase in fluid pressure was promoted by the impermeable barrier constituted by the slates, a fracturing and veining event likely occurred, leading to the main $\mathrm{Sb}$ mineralization stage (Fig. 16c). Fracturing is clearly found to be contemporaneous with and subsequent to the re-gional cleavage. Sb deposition occurred during the regional deforma-tion as highlighted by pressure shadows filled with $\mathrm{Sb}$ and stibnite (Fig. 16c) and by extensional veins affected by cleavage. Fluid over-pressure cycling is recorded by flat extensional veins (Fig. 16d). Crack-seal evidence and reactivation of reverse faults were coupled with a temperature decrease, as revealed by the Sb-minerals evolution se-quence (Fig. 16e). As discussed above, the Le Semnon Sb-Au hydro-thermal event is interpreted as a progressive cooling of a single mi-neralizing event and consequently it is believed that the U-Pb and ${ }^{40} \mathrm{Ar} /{ }^{39} \mathrm{Ar}$ results show that the Sb-Au mineralization is early in the Variscan history of Central Brittany and probably happened very close to the emplacement age of dolerite dyke swarms at ca. $360 \mathrm{Ma}$. Dis-turbing event(s), highlighted by the ${ }^{40} \mathrm{Ar} /{ }^{39} \mathrm{Ar}$ spectra of some illite grains, rather reflects a subsequent fluid flow disconnected from the mineralizing event, possibly meteoric in origin.

The Le Semnon Sb-Au deposit has a number of key features typical of orogenic gold deposits (Groves et al., 1998; McCuaig and Kerrich, 1998; Ridley and Diamond, 2000; Bierlein and Maher, 2001; Goldfarb et al., 2001, 2005; Goldfarb and Groves, 2015; Groves et al., 2003; Bierlein et al., 2006), including the strong structural control on the $\mathrm{Sb}-\mathrm{Au}$ mineralization, a wrenching tectonic regime, predominant aqueous-carbonic fluids, and an $\mathrm{Au}-$ As-Sb mineral assemblage. The deposit was emplaced at very shallow levels ( $<2.5 \mathrm{~km}$ depth) and could correspond to the so-called epizonal Sb-Au ( $\leq 5$ $\mathrm{km}, 150-300{ }^{\circ} \mathrm{C}$ ) mineralization in the classification for orogenic gold deposits proposed by Groves et al. (1998). However, the recorded temperatures here are far too high for fluids in thermal equilibrium with the country rocks because this would imply a geothermal gradient of about 100 ${ }^{\circ} \mathrm{C} / \mathrm{km}$. According to Obolensky et al. (2009), such disequilibrium with the host rocks could indicate deep-level circulation solutions for the ore-forming fluids. A thermal source is needed to promote upward deep fluids flow toward the surface.

The Le Semnon Sb-Au deposit is located in a part of the orogen (i.e. the Central Brittany) that never experienced crustal thickening (Gumiaux et al., 2004b). Variscan granitic plutons are rather scarce (Fig. 1) and are younger than the $\mathrm{Sb}$-Au mineralization. Possible as-sumptions about the thermal source could be either deep metamorphic dehydration processes involving a very fast upward fluid flow unable to equilibrate with country rocks, or a magmatic intrusion able to mobilize fluids in the surrounding rocks. Taking into consideration the regional geology of Central Brittany, the mafic magmatism appears as the only event that could have induced such thermal effect. Consequently, the Le Semnon Sb-Au deposit is likely the result of a focused discharge of mineralizing fluids mobilized by emplacement of mafic magmas at ca. 360 Ma throughout the area (Pochon et al., 2016b). Thus, the me-tallogenic model we established for the Le Semnon Sb-Au deposit (hy-drodynamics, structural controls, associated magmatism, deposition depth and timing) is quite different from the one developed for the Sb mineralization of the FMC. Therefore, we proposed that through an orogen, various mechanisms at different geodynamical stages are able to mobilize, pre-concentrate, and trap fluidsmobile metals (such as $\mathrm{Sb}$ and $\mathrm{As}$ ); various mineralizing peak are then expected.

\section{Conclusions}

New structural constraints for the Le Semnon Sb-Au deposit indicate that at least a major part of the $\mathrm{Sb}-\mathrm{Au}$ mineralization was con-temporaneous with the regional deformation. The local tectonic setting, the veins geometric arrangement and evidence of crack-seal mechanism reveal that the Sb-Au mineralization occurred at shallow depth and are linked to supralithostatic fluid overpressure conditions associated with a small-scale fault valve mechanism. Mineralogical and geochronolo-gical results strongly suggest that the Le Semnon Sb-Au mineralization formed early during the Variscan orogeny and was coeval with the emplacement of mafic magmatism at ca. 360 $\mathrm{Ma}$. Indeed, $\mathrm{U}-\mathrm{Pb}$ dating demonstrates a pervasive $\mathrm{Sb}$-rich hydrothermal alteration affecting the dolerite dyke just after its emplacement $(358.5 \pm 7.1$ Ma) whereas ${ }^{40} \mathrm{Ar} /{ }^{39} \mathrm{Ar}$ dating shows that illite associated with stibnite crystallized at ca. 358-359 Ma. Furthermore, the paragenetic sequence indicates a gradually decrease in temperature during successive stages of $\mathrm{Sb}$ en-richment. Fluid inclusions data consistently document cooling from 330 to $240{ }^{\circ} \mathrm{C}$ for the $\mathrm{Sb}$ mineralization events. Thus, mineralogical, geochronological and physicochemical data are consistent with a single mineralizing event rather than with a contrasted style of mineralization at different times. Such hot temperature fluids (at least $330{ }^{\circ} \mathrm{C}$ ) close to the surface $(<2.5 \mathrm{~km}$ depth) imply a shallow thermal source. In the Armorican Massif, the most likely thermal source able to mobilize large-scale fluids is the widespread mafic magmatic event at $360 \mathrm{Ma}$. Our results provide a new framework for future mining exploration of an-timony and gold in the Western European Variscan belt.

\section{Acknowledgements}

This work was funded by the Bureau des Recherches Géologiques et Minières (BRGM), the region of Brittany, the Observatoire des Sciences de l'Univers de Rennes (OSUR), with contributions from INSU through CESSUR Project. The authors thank Xavier Le Coz for thin sections, Jessica Langlade (UBO) for EPMA analyses, Johann Tuduri for his help about stability diagram of antimony species and the museum of Geosciences Rennes for samples collection. We gratefully thank Dr. F. Pirajno for his efficient editorial handling and two anonymous re-viewers for their helpful and pertinent comments. 


\section{Appendix A.1}

Operating conditions for the LA-ICP-MS equipment.

$\mathrm{U}-\mathrm{Pb}$ apatite and rutile analyses

Laboratory \& Sample Preparation

Laboratory name

Sample type/mineral

Imaging

Laser ablation system Make, Model \& type

Ablation cell

Laser wavelength

Pulse width

Fluence

Repetition rate

Spot size

Sampling mode/pattern

Carrier gas

Background collection

Ablation duration

Wash-out delay

Cell carrier gas flow (He)

ICP-MS Instrument

Make, Model \& type

Sample introduction

RF power

Sampler, skimmer cones

Extraction lenses

Make-up gas flow (Ar)

Detection system

Data acquisition protocol

Scanning mode

Detector mode

Masses measured

Integration time per peak

Sensitivity/Efficiency

Dwell time per isotope

Data Processing

Gas blank

Calibration strategy

Reference Material info

Data processing package used

Quality control/

Validation
Géosciences Rennes, UMR CNRS 6118, Rennes, France

Apatite and rutile

CL: RELION CL instrument, Olympus Microscope BX51WI, Leica Color Camera DFC 420C

ESI NWR193UC, Excimer

ESI NWR TwoVol2

$193 \mathrm{~nm}$

$<5 \mathrm{~ns}$

$6.5 \mathrm{~J} / \mathrm{cm}^{2}$

$5 \mathrm{~Hz}$

$100 \times 20 \mu \mathrm{m}$ (apatite) or $65 \times 20 \mu \mathrm{m}$ (rutile)

Single spot

$100 \% \mathrm{He}$, Ar make-up gas and N2 (3 ml/mn) combined using in-house smoothing device

$20 \mathrm{~s}$

$60 \mathrm{~s}$

$15 \mathrm{~s}$

$0.75 \mathrm{l} / \mathrm{min}$

Agilent 7700x, Q-ICP-MS

Via conventional tubing

$1350 \mathrm{~W}$

$\mathrm{Ni}$

X type

$0.87 \mathrm{l} / \mathrm{min}$

Single collector secondary electron multiplier

Time-resolved analysis

Peak hopping, one point per peak

Pulse counting, dead time correction applied, and analog mode when signal intensity $>\sim 10^{6} \mathrm{cps}$ ${ }^{43} \mathrm{Ca},{ }^{204}(\mathrm{Hg}+\mathrm{Pb}),{ }^{206} \mathrm{~Pb},{ }^{207} \mathrm{~Pb},{ }^{208} \mathrm{~Pb},{ }^{232} \mathrm{Th},{ }^{238} \mathrm{U}$

$10-30 \mathrm{~ms}$

$28,000 \mathrm{cps} / \mathrm{ppm} \mathrm{Pb}(50 \mu \mathrm{m}, 10 \mathrm{~Hz})$

5-70 ms depending on the masses

20 s on-peak

Madagascar apatite R10 rutile used as primary reference material, Durango and McClure apatites and R19 rutile used as secondary reference material (quality control)

Madagascar (Thomson et al., 2012)

Durango (McDowell et al., 2005)

McClure (Schoene and Bowring, 2006)

R10 and R19 (Zack et al., 2011)

Iolite (Paton et al., 2010) and VizualAge_UcomPbine (Chew et al., 2014) for apatite, GLITTER® (Van Achterbergh et al., 2001) for rutile

Durango: Weighted average ${ }^{207} \mathrm{~Pb}$ corrected age $=31.47 \pm 0.87 \mathrm{Ma}(\mathrm{MSWD}=2.7)$

McClure: Weighted average ${ }^{207} \mathrm{~Pb}$ corrected age $=529.7 \pm 5.7 \mathrm{Ma}(\mathrm{MSWD}=3.1)$

R19: Weighted average ${ }^{207} \mathrm{~Pb}$ corrected age $=476 \pm 30 \mathrm{Ma}(\mathrm{MSWD}=1.6)$ 
Illite 40Ar/39Ar analytical data.

Laser power $\quad{ }^{40} \mathrm{Ar} A$ tm $\quad$ Error ${ }^{40} \mathrm{Ar} \quad{ }^{39} \mathrm{ArK} \quad$ Error ${ }^{39} \mathrm{Ar} \quad{ }^{38} \mathrm{Ar} \quad$ Error ${ }^{38} \mathrm{Ar} \quad{ }^{37} \mathrm{Ar} \quad$ Error ${ }^{37} \mathrm{Ar} \quad{ }^{36} \mathrm{Ar} \quad$ Error ${ }^{36} \mathrm{Ar} \quad{ }^{40} \mathrm{Ar}^{*} /{ }^{39} \mathrm{ArK} \quad$ Error

${ }^{40} \mathrm{Ar}^{*} / 39 \mathrm{ArK}$

Apparent age (Ma) Error Age (Ma) Delay to irradiation (day)

\begin{tabular}{|c|c|c|c|c|c|c|c|c|c|c|c|c|c|c|c|}
\hline \multicolumn{16}{|l|}{ SEMAP1 } \\
\hline 250 & 816.382 & 1.03521 & 27.486 & 0.05 & $1 \mathrm{E}-06$ & 0.02 & 0.13 & 0.03 & 1.057 & 0.0157 & 18.806249 & 0.191535 & 324.74 & 3.3616 & 130.809722 \\
\hline 290 & 799.387 & 1.17385 & 26.612 & 0.11 & 0.0015 & 0.02 & 0.16 & 0.02 & 0.8962 & 0.0247 & 20.534146 & 0.295704 & 351.85 & 4.8663 & 130.829861 \\
\hline 350 & 2298.02 & 0.79901 & 95.641 & 0.16 & 0.0059 & 0.02 & 0.28 & 0.03 & 1.2855 & 0.0311 & 20.336538 & 0.111074 & 348.77 & 2.3329 & 130.85 \\
\hline 380 & 2819 & 1.312 & 127.56 & 0.2 & $1 \mathrm{E}-06$ & 0.02 & 0.38 & 0.03 & 1.0181 & 0.016 & 19.97617 & 0.061982 & 343.14 & 1.8188 & 130.870139 \\
\hline 410 & 7227.58 & 3.75089 & 341.81 & 0.22 & $1 \mathrm{E}-06$ & 0.02 & 0.58 & 0.04 & 1.6468 & 0.0252 & 19.928399 & 0.043227 & 342.39 & 1.678 & 130.920139 \\
\hline 430 & 21383 & 5.36127 & 1058.6 & 0.49 & 0.0435 & 0.02 & 1.28 & 0.05 & 2.6599 & 0.0329 & 19.643497 & 0.032675 & 337.93 & 1.6012 & 130.939583 \\
\hline 440 & 12845.6 & 5.7197 & 649.87 & 0.55 & 0.0104 & 0.02 & 0.68 & 0.04 & 0.8229 & 0.0157 & 19.567515 & 0.034059 & 336.74 & 1.6036 & 130.959722 \\
\hline 460 & 7509.28 & 2.45967 & 381.84 & 0.4 & 0.0055 & 0.02 & 0.4 & 0.04 & 0.4326 & 0.0204 & 19.505039 & 0.037944 & 335.76 & 1.6213 & 130.979861 \\
\hline 520 & 11888.1 & 3.40649 & 607.51 & 0.47 & $1 \mathrm{E}-06$ & 0.03 & 0.43 & 0.02 & 0.4458 & 0.0158 & 19.521805 & 0.032136 & 336.02 & 1.591 & 131.020139 \\
\hline 600 & 2915.15 & 1.52958 & 149.62 & 0.22 & $1 \mathrm{E}-06$ & 0.03 & 0.11 & 0.02 & 0.1067 & 0.0133 & 19.442641 & 0.047938 & 334.78 & 1.6818 & 131.039583 \\
\hline Fusion & 1775.93 & 1.01595 & 92.281 & 0.11 & 0.001 & 0.03 & 0.11 & 0.02 & 0.1155 & 0.0166 & 19.046001 & 0.063863 & 328.53 & 1.788 & 131.059722 \\
\hline $\mathrm{J}$ parameter & & 0.01046 & & & & & & & & & & & & & \\
\hline error J & & $4.3 \mathrm{E}-05$ & & & & & & & & & & & & & \\
\hline $\begin{array}{l}\text { Mass Discriminatio } \\
\qquad(1+\mathrm{e})\end{array}$ & & 1.00941 & & & & & & & & & & & & & \\
\hline \multicolumn{16}{|l|}{$\begin{array}{l}\text { Err Discrimination } \\
\text { SEMAP2 }\end{array}$} \\
\hline 270 & 1741.38 & 1.55941 & 48.661 & 0.13 & 0.0045 & 0.02 & 0.34 & 0.03 & 2.661 & 0.0168 & 20.238804 & 0.161383 & 347.25 & 2.961 & 125.809722 \\
\hline 310 & 1740.97 & 1.32427 & 71.771 & 0.13 & $1 \mathrm{E}-06$ & 0.02 & 0.34 & 0.03 & 0.9737 & 0.024 & 20.534658 & 0.116177 & 351.86 & 2.3987 & 125.829861 \\
\hline 340 & 568.642 & 0.74533 & 26.044 & 0.08 & $1 \mathrm{E}-06$ & 0.02 & 0.21 & 0.03 & 0.2059 & 0.0341 & 19.736586 & 0.388255 & 339.39 & 6.2749 & 125.85 \\
\hline 380 & 5543.66 & 4.00484 & 212.94 & 0.34 & $1 \mathrm{E}-06$ & 0.01 & 0.75 & 0.02 & 4.289 & 0.0415 & 20.417974 & 0.088921 & 350.04 & 2.0924 & 125.889583 \\
\hline 390 & 11356.4 & 4.19132 & 501.78 & 0.71 & 0.0099 & 0.02 & 0.9 & 0.03 & 5.0503 & 0.0133 & 19.907152 & 0.051324 & 342.06 & 1.7319 & 125.909722 \\
\hline 400 & 1883.93 & 1.18406 & 94.275 & 0.16 & $1 \mathrm{E}-06$ & 0.01 & 0.21 & 0.03 & 0.2328 & 0.0133 & 19.439449 & 0.061013 & 334.73 & 1.7832 & 125.939583 \\
\hline 430 & 16691.6 & 3.31391 & 829.38 & 1.44 & $1 \mathrm{E}-06$ & 0.02 & 0.97 & 0.05 & 2.1732 & 0.0327 & 19.537499 & 0.046652 & 336.27 & 1.6782 & 125.959722 \\
\hline 450 & 3432.9 & 6.16727 & 176.91 & 0.37 & $1 \mathrm{E}-06$ & 0.02 & 0.24 & 0.03 & 0.1585 & 0.0182 & 19.311677 & 0.066572 & 332.72 & 1.8254 & 126.009722 \\
\hline 500 & 21648.3 & 7.90709 & 1108.1 & 0.67 & $1 \mathrm{E}-06$ & 0.02 & 0.98 & 0.04 & 0.9811 & 0.0189 & 19.445818 & 0.030626 & 334.83 & 1.579 & 126.029861 \\
\hline 530 & 2863.08 & 1.24588 & 147.81 & 0.21 & 0.0267 & 0.02 & 0.24 & 0.03 & 0.1595 & 0.0149 & 19.223422 & 0.048961 & 331.33 & 1.6769 & 126.05 \\
\hline 580 & 1022.15 & 1.07102 & 52.725 & 0.12 & 0.0015 & 0.02 & 0.2 & 0.04 & 0.1316 & 0.0148 & 18.831318 & 0.09932 & 325.14 & 2.1456 & 126.059722 \\
\hline 660 & 3342.57 & 1.83469 & 172.09 & 0.22 & $1 \mathrm{E}-06$ & 0.03 & 0.31 & 0.03 & 0.1124 & 0.0234 & 19.400889 & 0.054705 & 334.12 & 1.7299 & 126.109722 \\
\hline 900 & 1102.06 & 0.47397 & 56.881 & 0.14 & $1 \mathrm{E}-06$ & 0.02 & 0.15 & 0.02 & 0.0922 & 0.0206 & 19.07234 & 0.11818 & 328.95 & 2.3792 & 126.129861 \\
\hline Fusion & 111.579 & 0.25464 & 5.7076 & 0.04 & $1 \mathrm{E}-06$ & 0.02 & 0.05 & 0.03 & 0.0244 & 0.0251 & 18.488889 & 1.287367 & 319.72 & 20.455 & 126.15 \\
\hline $\mathrm{J}$ parameter & & 0.01046 & & & & & & & & & & & & & \\
\hline error $\mathrm{J}$ & & $4.3 \mathrm{E}-05$ & & & & & & & & & & & & & \\
\hline $\begin{array}{l}\text { Mass Discriminatio } \\
\qquad(1+\mathrm{e})\end{array}$ & & 1.00941 & & & & & & & & & & & & & \\
\hline $\begin{array}{l}\text { Err Discrimination } \\
\text { Laser power }\end{array}$ & ${ }^{40} \mathrm{ArAtm}$ & $\begin{array}{l}0.00132 \\
\text { Error }\end{array}$ & ${ }^{39} \mathrm{ArK}$ & Error ${ }^{39} \mathrm{Ar}$ & $38 \mathrm{Ar}$ & Error ${ }^{38} \mathrm{Ar}$ & ${ }^{37} \mathrm{Ar}$ & Error ${ }^{37} \mathrm{Ar}$ & 36 $\mathrm{Ar}$ & Error ${ }^{36} \mathrm{Ar}$ & ${ }^{40} \mathrm{Ar}^{*} /{ }^{39} \mathrm{ArK}$ & $\begin{array}{l}\text { Error } \\
{ }^{40} \mathrm{Ar}^{*} /{ }^{39} \mathrm{ArK}\end{array}$ & Apparent age (Ma) & Error Age (Ma) & Delay to irradiation (day) \\
\hline \multicolumn{16}{|l|}{ SEMJB1 } \\
\hline 250 & 2573.95 & 1.50065 & 93.43 & 0.16 & $1 \mathrm{E}-06$ & 0.02 & 0.16 & 0.03 & 1.464 & 0.0161 & 23.240816 & 0.084959 & 394.64 & 2.1798 & 126.809722 \\
\hline 290 & 1606.17 & 1.26272 & 75.548 & 0.17 & $1 \mathrm{E}-06$ & 0.02 & 0.27 & 0.03 & 0.2556 & 0.0189 & 20.463944 & 0.093088 & 351.77 & 2.1435 & 126.829861 \\
\hline 340 & 7563.07 & 3.44536 & 366.84 & 0.34 & 0.0137 & 0.02 & 0.78 & 0.04 & 0.3828 & 0.0316 & 20.491905 & 0.043456 & 352.21 & 1.7166 & 126.85 \\
\hline 360 & 6802.98 & 4.38849 & 338.36 & 0.37 & 0.0011 & 0.02 & 1.1 & 0.03 & 0.2701 & 0.0221 & 20.049047 & 0.041934 & 345.28 & 1.6815 & 126.870139 \\
\hline 380 & 8098.36 & 3.83748 & 407.39 & 0.37 & $1 \mathrm{E}-06$ & 0.03 & 0.57 & 0.03 & 0.2673 & 0.0278 & 19.858305 & 0.039154 & 342.29 & 1.6537 & 126.909722 \\
\hline 400 & 6031.85 & 7.87757 & 303.83 & 0.25 & 0.0252 & 0.03 & 0.29 & 0.03 & 0.2656 & 0.0281 & 19.768632 & 0.049146 & 340.88 & 1.7132 & 126.929861 \\
\hline 430 & 73561.2 & 17.2322 & 3744.8 & 0.98 & $1 \mathrm{E}-06$ & 0.03 & 1.2 & 0.05 & 1.2978 & 0.0427 & 19.709926 & 0.027504 & 339.96 & 1.5855 & 126.95 \\
\hline
\end{tabular}




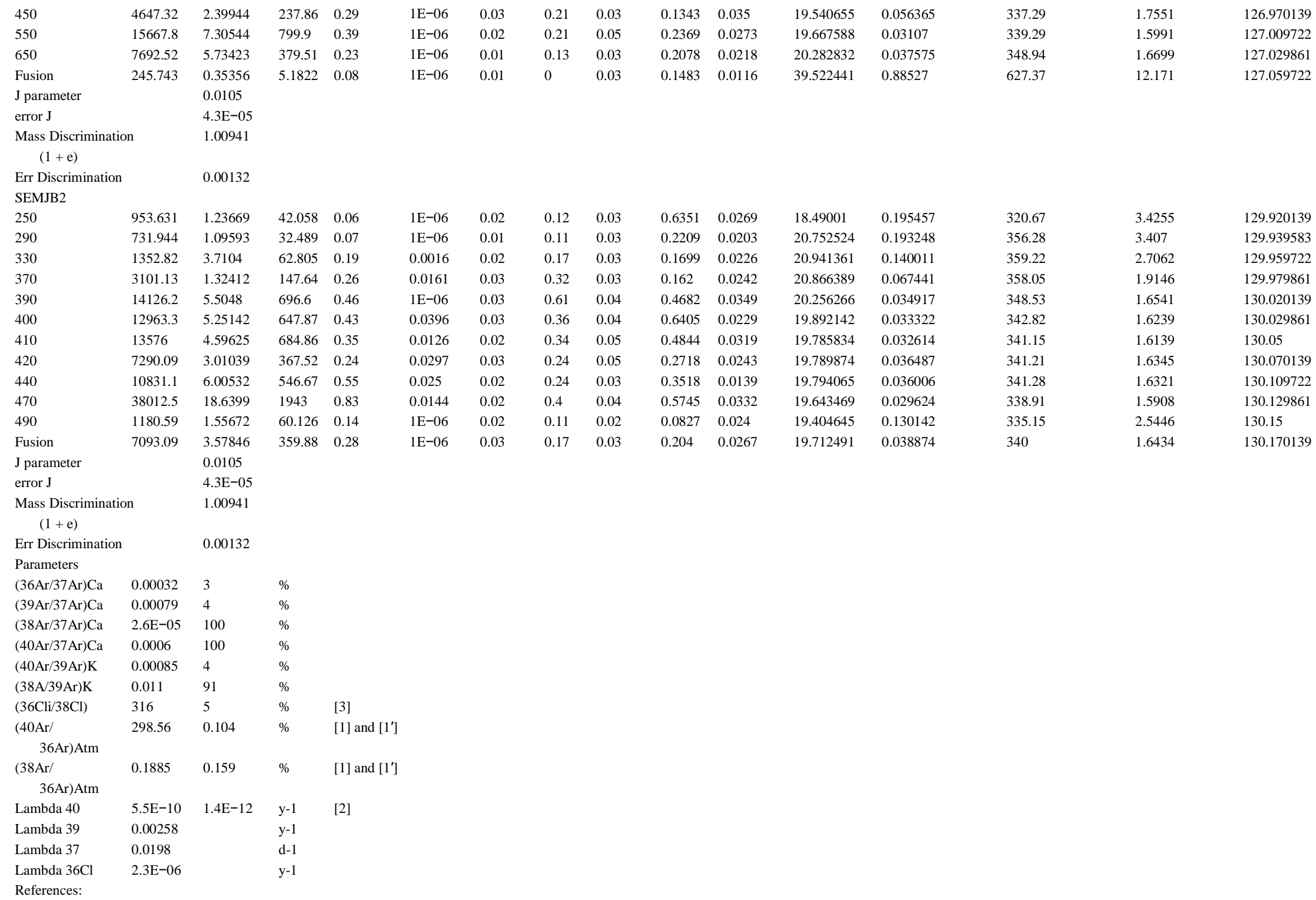

[1] Lee, JY, Marti, K, Severinghaus, JP, Kawamura, K, Yoo, HS, Lee, JB, Kim, JS (2006). A redetermination of the isotopic abundances of atmospheric Ar. Geochimica Cosmochimica Acta, 70, 4507-4512. [1'] Mark, DF,

Stuart, FM, De Podesta, M (2011). New high-precision measurements of the isotopic composition of atmospheric argon. Geochimica Cosmochimica Acta, 75, 7494-7501.

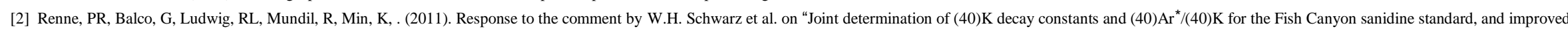
accuracy for (40)Ar/(39)Ar geochronology" by PR Renne et al. (2010). Geochimica Cosmochimica Acta, 75, 5097-5100.

[3] York, D, Personnal Communication - McMaster reactor

Regression method: York, D. (1969). Least-squares fitting of a straight line with correlated errors. Earth Planet. Sci. Lett. 5, 320-4.

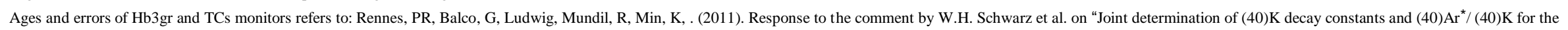
Fish Canyon sanidine standard, and improved accuracy for (40)Ar/(39)Ar geochronology" by PR Renne et al. (2010). Geochimica Cosmochimica Acta, 75, 5097-5100. 
Electron microprobe analyses of ankerite from the Semnon $\mathrm{Sb}$-Au deposit.

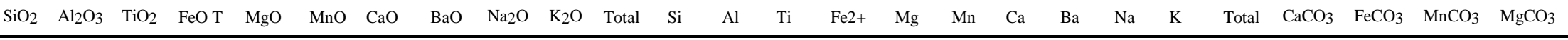

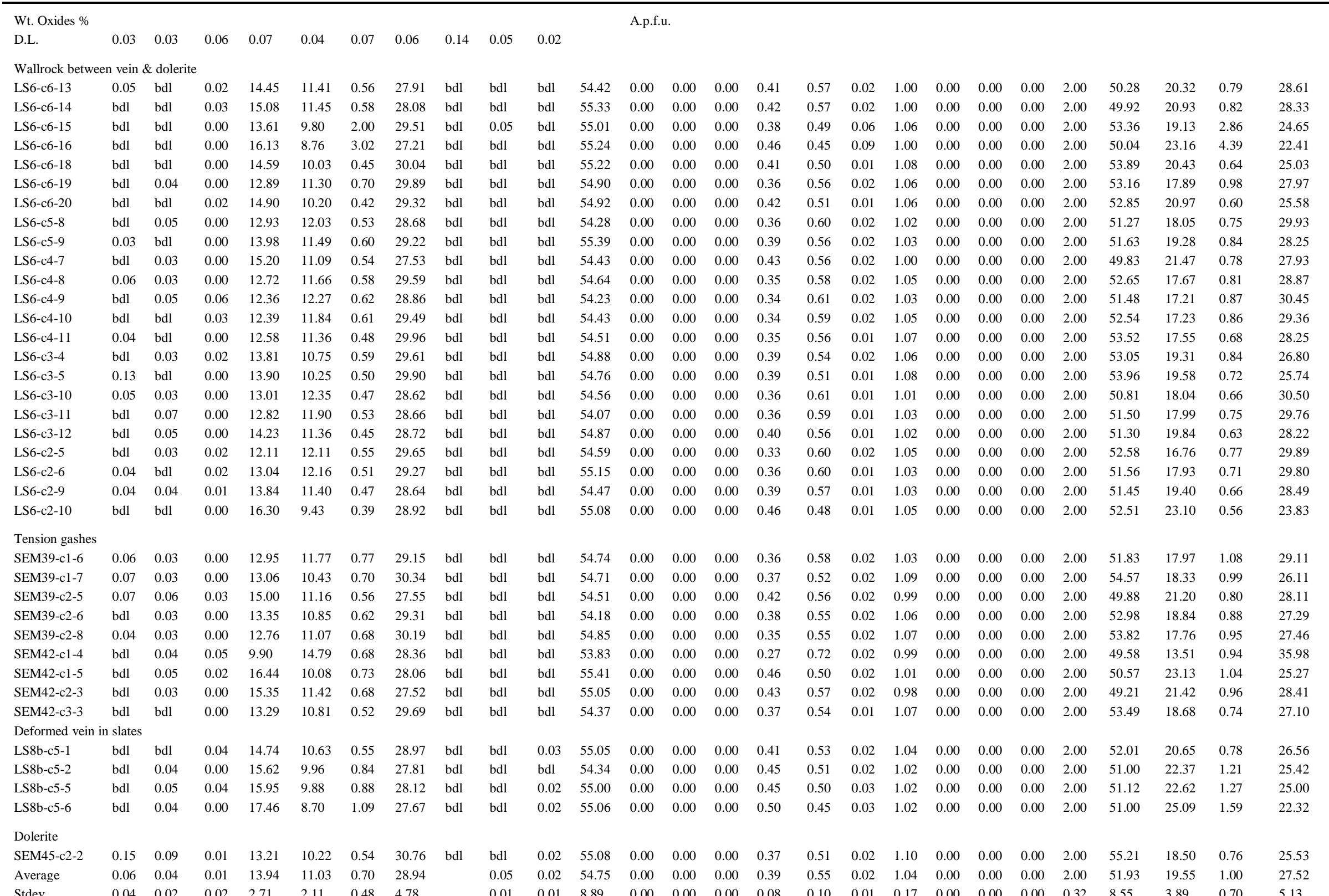

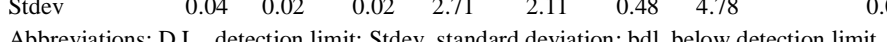


Electron microprobe analyses of phyllosilicates from the Semnon $\mathrm{Sb}$-Au deposit.

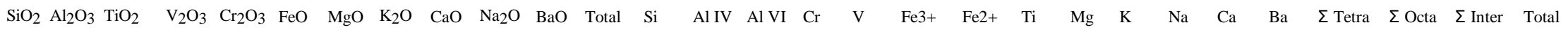

\begin{tabular}{|c|c|c|c|c|c|c|c|c|c|c|c|c|c|c|c|c|c|c|c|c|c|c|c|c|c|c|c|c|c|}
\hline \multirow{2}{*}{$\begin{array}{l}\text { Illite } \\
\text { D.L. }\end{array}$} & \multicolumn{12}{|c|}{ Wt. Oxides \% } & \multicolumn{17}{|c|}{ A.p.f.u. } \\
\hline & 0.04 & 0.04 & 0.06 & 0.03 & 0.02 & 0.07 & 0.03 & 0.03 & 0.05 & 0.04 & 0.14 & & & & & & & & & & & & & & & & & & \\
\hline \multicolumn{30}{|c|}{ Wallrock between vein \& dolerite } \\
\hline LS6-c6-1 & 47.4 & 37.02 & - & 0.08 & - & 0.37 & 0.29 & 7.86 & 0.08 & 0.63 & 0.20 & 93.99 & 3.13 & 0.87 & 2.00 & 0.00 & 0.00 & 0.00 & 0.02 & 0.00 & 0.03 & 0.66 & 0.08 & 0.01 & 0.01 & 4.00 & 2.05 & 0.75 & 6.81 \\
\hline LS6-c6-2 & 47.1 & 36.79 & 0.08 & 0.08 & - & 0.41 & 0.38 & 7.65 & - & 0.46 & - & 93.11 & 3.13 & 0.87 & 2.01 & 0.00 & 0.00 & 0.00 & 0.02 & 0.00 & 0.04 & 0.65 & 0.06 & 0.00 & 0.00 & 4.00 & 2.07 & 0.71 & 6.78 \\
\hline LS6-c6-3 & 47.1 & 37.20 & 0.09 & 0.06 & - & 0.34 & 0.33 & 7.35 & - & 0.48 & - & 93.09 & 3.12 & 0.88 & 2.02 & 0.00 & 0.00 & 0.00 & 0.02 & 0.00 & 0.03 & 0.62 & 0.06 & 0.00 & 0.00 & 4.00 & 2.08 & 0.68 & 6.77 \\
\hline LS6-c6-4 & 47.1 & 36.75 & 0.12 & 0.09 & - & 0.39 & 0.31 & 7.50 & 0.07 & 0.51 & - & 92.97 & 3.13 & 0.87 & 2.01 & 0.00 & 0.00 & 0.00 & 0.02 & 0.01 & 0.03 & 0.64 & 0.07 & 0.00 & 0.00 & 4.00 & 2.07 & 0.71 & 6.78 \\
\hline LS6-c6-5 & 47.5 & 36.47 & 0.07 & 0.07 & - & 0.40 & 0.37 & 7.03 & 0.11 & 0.41 & - & 92.53 & 3.16 & 0.84 & 2.01 & 0.00 & 0.00 & 0.00 & 0.02 & 0.00 & 0.04 & 0.60 & 0.05 & 0.01 & 0.00 & 4.00 & 2.08 & 0.66 & 6.73 \\
\hline LS6-c6-6 & 47.0 & 36.64 & - & 0.08 & - & 0.43 & 0.37 & 7.59 & 0.07 & 0.50 & - & 92.85 & 13 & 0.87 & 2.00 & 0.00 & 0.00 & 0.00 & 0.02 & 0.00 & 0.04 & 0.64 & 0.06 & 0.01 & 0.00 & 4.00 & 2.07 & 0.71 & 6.78 \\
\hline LS6-c6-7 & 47.6 & 36.78 & 0.10 & 0.06 & - & 0.39 & 0.33 & 7.35 & - & 0.35 & - & 93.16 & 3.15 & 0.85 & 2.02 & 0.00 & 0.00 & 0.00 & 0.02 & 0.00 & 0.03 & 0.62 & 0.05 & 0.00 & 0.00 & 4.00 & 2.08 & 0.67 & 6.74 \\
\hline LS6-c6-8 & 47.4 & 36.85 & - & 0.07 & - & 0.38 & 0.34 & 7.58 & bdl & 0.38 & - & 93.09 & 3.14 & 0.86 & 2.02 & 0.00 & 0.00 & 0.00 & 0.02 & 0.00 & 0.03 & 0.64 & 0.05 & 0.00 & 0.00 & 4.00 & 2.07 & 0.69 & 6.76 \\
\hline LS6-c6-9 & 45.8 & 35.35 & - & 0.08 & - & 0.43 & 0.35 & 7.42 & - & 0.47 & - & 89.99 & 3.14 & 0.86 & 2.00 & 0.00 & 0.00 & 0.00 & 0.02 & 0.00 & 0.04 & 0.65 & 0.06 & 0.00 & 0.00 & 4.00 & 2.07 & 0.71 & 6.78 \\
\hline LS6-c6-10 & 47.0 & 36.53 & 0.07 & 0.08 & - & 41 & 0.37 & 7.75 & 0.06 & 0.50 & 0.17 & 92.92 & 3.13 & 0.87 & 2.00 & 0.00 & 0.00 & 0.00 & 0.02 & 0.00 & 0.04 & 0.66 & 0.06 & 0.00 & 0.00 & 4.00 & 2.06 & .73 & 6.79 \\
\hline LS6-c6-11 & 47.2 & 37.19 & - & 0.05 & - & 0.33 & 0.34 & 7.85 & 0.06 & 0.50 & bdl & 93.71 & 3.12 & 0.88 & 2.01 & 0.00 & 0.00 & 0.00 & 0.02 & 0.00 & 0.03 & 0.66 & 0.06 & 0.00 & 0.00 & 4.00 & 2.07 & 73 & 6.80 \\
\hline LS6-c6-12 & 46.9 & 36.89 & - & 0.07 & - & .24 & 0.33 & 7.84 & - & 0.51 & - & 92.83 & 3.12 & 0.88 & 2.01 & 0.00 & 0.00 & 0.00 & 0.01 & 0.00 & 0.03 & 0.67 & 0.07 & 0.00 & 0.00 & 4.00 & 2.07 & .73 & 6.80 \\
\hline LS6-c5-1 & 46.6 & 36.86 & 0.06 & 0.08 & - & .33 & 0.35 & 7.44 & 0.13 & 0.44 & - & 92.40 & 3.11 & 0.89 & 2.02 & 0.00 & 0.00 & 0.00 & 0.02 & 0.00 & 0.03 & 0.63 & 0.06 & 0.01 & 0.00 & 4.00 & 2.0 & 0.70 & 6.78 \\
\hline LS6-c5-2 & 47.0 & 36.75 & 0.09 & 0.06 & - & 35 & 0.35 & 7.60 & 0.07 & 0.41 & - & 92.74 & 3.13 & 0.87 & 2.01 & 0.00 & 0.00 & 0.00 & 0.02 & 0.00 & 0.03 & 0.64 & 0.05 & 0.00 & 0.00 & 4.00 & 2.07 & 0.70 & 6.77 \\
\hline LS6-c5-3 & 47.1 & 36.49 & 0.15 & 0.05 & - & .38 & 0.33 & 7.46 & 0.10 & 0.52 & - & 92.60 & 3.14 & 0.86 & 2.00 & 0.00 & 0.00 & 0.00 & 0.02 & 0.01 & 0.03 & 0.63 & 0.07 & 0.01 & 0.00 & 4.00 & 2.06 & 1 & 6.77 \\
\hline LS6-c5-4 & 46.9 & 37.03 & 0.07 & 0.09 & - & 0.35 & 0.31 & 7.35 & 0.19 & 0.48 & - & 92.92 & 3.12 & 0.88 & 2.01 & 0.00 & 0.00 & 0.00 & 0.02 & 0.00 & 0.03 & 0.62 & 0.06 & 0.01 & 0.00 & 4.00 & 2.07 & 0.70 & 6.77 \\
\hline LS6-c5-6 & 46.6 & 36.72 & 0.06 & 0.06 & - & 0.28 & 0.32 & 7.57 & - & 0.50 & - & 92.22 & 3.12 & 0.88 & 2.02 & 0.00 & 0.00 & 0.00 & 0.02 & 0.00 & 0.03 & 0.65 & 0.06 & 0.00 & 0.00 & 4.00 & 2.07 & 0.71 & 6.78 \\
\hline LS6-c5-7 & 46.9 & 36.67 & 0.08 & 0.09 & - & 0.29 & 0.33 & 7.76 & - & 0.54 & - & 92.79 & 3.12 & 0.88 & 2.01 & 0.00 & 0.00 & 0.00 & 0.02 & 0.00 & 0.03 & 0.66 & 0.07 & 0.00 & 0.00 & 4.00 & 2.06 & 0.73 & 6.79 \\
\hline LS6-c5-10 & 47.5 & 36.97 & - & 0.06 & - & 0.30 & 0.32 & 7.59 & 0.12 & 0.58 & - & 93.58 & 3.13 & 0.87 & 2.01 & 0.00 & 0.00 & 0.00 & 0.02 & 0.00 & 0.03 & 0.64 & 0.07 & 0.01 & 0.00 & 4.00 & 2.06 & 0.72 & 6.78 \\
\hline LS6-c5-11 & 46.9 & 36.81 & 0.12 & 0.10 & - & 0.37 & 0.34 & 7.64 & 0.07 & 0.47 & 0.22 & 93.05 & 3.12 & 0.88 & 2.00 & 0.00 & 0.01 & 0.00 & 0.02 & 0.01 & 0.03 & 0.65 & 0.06 & 0.01 & 0.01 & 4.00 & 2.07 & 0.72 & 6.79 \\
\hline LS6-c5-12 & 46.8 & 37.03 & 0.10 & 0.07 & - & 0.30 & 0.31 & 7.89 & 0.06 & 0.56 & - & 93.21 & 3.11 & 0.89 & 2.01 & 0.00 & 0.00 & 0.00 & 0.02 & 0.01 & 0.03 & 0.67 & 0.07 & 0.00 & 0.00 & 4.00 & 2.06 & .74 & 6.81 \\
\hline LS6-c5-13 & 47.3 & 36.86 & - & 0.09 & - & 0.35 & 0.33 & 7.77 & 0.08 & 0.53 & - & 93.36 & 3.13 & 0.87 & 2.01 & 0.00 & 0.01 & 0.00 & 0.02 & 0.00 & 0.03 & 0.66 & 0.07 & 0.01 & 0.00 & 4.00 & 2.06 & 0.73 & 6.79 \\
\hline LS6-c4-1 & 47.4 & 36.93 & - & 0.06 & - & 0.37 & 0.28 & 7.67 & - & 0.55 & - & 93.38 & 3.13 & 0.87 & 2.01 & 0.00 & 0.00 & 0.00 & 0.02 & 0.00 & 0.03 & 0.65 & 0.07 & 0.00 & 0.00 & 4.00 & 2.07 & 0.72 & 6.78 \\
\hline LS6-c4-2 & 47.4 & 36.88 & - & 0.08 & - & 0.33 & 0.32 & 7.64 & 0.05 & 0.60 & - & 93.41 & 3.14 & 0.86 & 2.01 & 0.00 & 0.00 & 0.00 & 0.02 & 0.00 & 0.03 & 0.64 & 0.08 & 0.00 & 0.00 & 4.00 & 2.06 & 0.72 & 6.79 \\
\hline LS6-c4-3 & 47.5 & 36.74 & 0.13 & 0.09 & - & 0.33 & 0.36 & 7.22 & 0.08 & 0.47 & - & 93.04 & 3.14 & 0.86 & 2.01 & 0.00 & 0.00 & 0.00 & 0.02 & 0.01 & 0.04 & 0.61 & 0.06 & 0.01 & 0.00 & 4.00 & 2.08 & 0.68 & 6.75 \\
\hline LS6-c4-4 & 46.8 & 36.25 & - & 0.09 & - & 0.48 & 0.32 & 7.32 & 0.15 & 0.53 & 0.17 & 92.16 & 3.14 & 0.86 & 2.00 & 0.00 & 0.00 & 0.00 & 0.03 & 0.00 & 0.03 & 0.63 & 0.07 & 0.01 & 0.00 & 4.00 & 2.07 & 0.71 & 6.78 \\
\hline LS6-c4-5 & 46.9 & 37.01 & - & 0.10 & - & 0.41 & 0.35 & 7.61 & 0.13 & 0.57 & - & 93.19 & 3.11 & 0.89 & 2.01 & 0.00 & 0.01 & 0.00 & 0.02 & 0.00 & 0.03 & 0.64 & 0.07 & 0.01 & 0.00 & 4.00 & 2.07 & 0.73 & 6.80 \\
\hline LS6-c4-6 & 46.9 & 36.75 & - & 0.08 & - & 0.39 & 0.33 & 7.49 & 0.09 & 0.53 & 0.14 & 92.78 & 3.12 & 0.88 & 2.01 & 0.00 & 0.00 & 0.00 & 0.02 & 0.00 & 0.03 & 0.64 & 0.07 & 0.01 & 0.00 & 4.00 & 2.07 & 0.72 & 6.78 \\
\hline LS6-c3-1 & 47.7 & 37.18 & 0.09 & 0.08 & 0.0 & 0.38 & 0.36 & 7.39 & 0.06 & 0.43 & 0.14 & 93.83 & 3.13 & 0.87 & 2.01 & 0.00 & 0.00 & 0.00 & 0.02 & 0.00 & 0.04 & 0.62 & 0.06 & 0.00 & 0.00 & 4.00 & 2.08 & 0.68 & 6.76 \\
\hline LS6-c3-2 & 47.5 & 36.76 & 0.11 & 0.08 & - & 0.41 & 0.36 & 7.11 & - & 0.47 & - & 92.89 & 3.14 & 0.86 & 2.01 & 0.00 & 0.00 & 0.00 & 0.02 & 0.01 & 0.04 & 0.60 & 0.06 & 0.00 & 0.00 & 4.00 & 2.08 & 0.66 & 6.74 \\
\hline LS6-c3-3 & 47.2 & 37.24 & 0.06 & 0.08 & - & 0.49 & 0.33 & 7.10 & 0.10 & 0.46 & - & 93.10 & 3.12 & 0.88 & 2.02 & 0.00 & 0.00 & 0.00 & 0.03 & 0.00 & 0.03 & 0.60 & 0.06 & 0.01 & 0.00 & 4.00 & 2.09 & 0.66 & 6.75 \\
\hline LS6-c3-6 & 47.0 & 36.92 & 0.07 & 0.09 & - & 0.44 & 0.33 & 7.27 & 0.09 & 0.62 & - & 92.88 & 3.12 & 0.88 & 2.01 & 0.00 & 0.00 & 0.00 & 0.02 & 0.00 & 0.03 & 0.62 & 0.08 & 0.01 & 0.00 & 4.00 & 2.07 & 0.70 & 6.78 \\
\hline LS6-c3-7 & 47.5 & 37.03 & - & 0.07 & - & .44 & 0.37 & 6.66 & 0.13 & 0.34 & - & 92.64 & 3.15 & 0.85 & 2.03 & 0.00 & 0.00 & 0.00 & 0.02 & 0.00 & 0.04 & 0.56 & 0.04 & 0.01 & 0.00 & 4.00 & 2.10 & 0.6 & 6.71 \\
\hline LS6-c3-8 & 47.2 & 37.02 & - & 0.1 & - & .52 & 0.34 & 7.65 & 0.13 & 0.52 & - & 93.57 & 3.12 & 0.88 & 2.00 & 0.00 & 0.01 & 0.00 & 0.03 & 0.00 & 0.03 & 0.65 & 0.07 & 0.01 & 0.00 & 4.00 & 2.07 & 0.72 & 6.79 \\
\hline LS6-c3-9 & 47.0 & 36.68 & 0.07 & 0.08 & - & .62 & 0.33 & 7.70 & 0.25 & 0.61 & - & 93.43 & 3.12 & 0.88 & 1.99 & 0.00 & 0.00 & 0.00 & 0.03 & 0.00 & 0.03 & 0.65 & 0.08 & 0.02 & 0.00 & 4.00 & 2.06 & 0.75 & 6.81 \\
\hline LS6-c2-1 & 47.6 & 36.72 & 0.1 & 0. & - & & 0.39 & 7.35 & 0. & 0. & - & 35 & 3.14 & 0.86 & 2. & 0.00 & 0.00 & 0.0 & & 0.00 & 0.04 & 0.62 & 0.06 & 0.01 & 0.00 & 4.00 & 2. & 0.69 & 5.76 \\
\hline LS6-c2-2 & 47.2 & 36.87 & - & 0.08 & - & & 0.29 & 7.33 & $0 .($ & 0. & - & 92.88 & 3.13 & 0.87 & 2.02 & 0.00 & 0.00 & 0.00 & 0.02 & 0.00 & 0.03 & 0.62 & 0.07 & 0.00 & 0.00 & 4.00 & 2.07 & 0.70 & 5.77 \\
\hline LS6-c2-3 & 47.2 & 36.57 & 0.07 & 0.08 & - & 38 & 0.35 & 7.10 & 0.08 & 0.5 & - & 92.42 & 3.14 & 0.86 & 2.01 & 0.00 & 0.00 & 0.00 & 0.02 & 0.00 & 0.04 & 0.60 & 0.07 & 0.01 & 0.00 & 4.00 & 2.08 & 0.67 & 6.75 \\
\hline LS6-c2-4 & 47.2 & 36.35 & 0.10 & 0.09 & - & .50 & 0.38 & 7.35 & 0.10 & 0. & be & 92.68 & 3.14 & 0.86 & 1.99 & 0.00 & 0.00 & 0.00 & 0.03 & 0.00 & 0.04 & 0.62 & 0.06 & 0.01 & 0.00 & 4.00 & 2.07 & 0.70 & 6.77 \\
\hline LS6-c2-7 & 47.3 & 36.74 & 0.0 & 0.06 & - & & 0.33 & 7.13 & 0.1 & 0. & - & 92.79 & 3.14 & 0.86 & 2.0 & 0.00 & 0.00 & 0.00 & 0.02 & 0.00 & 0.03 & 0.60 & 0.07 & 0.01 & 0.00 & 4.00 & 2.08 & 0.68 & 6.75 \\
\hline LS6-c2-8 & 46.9 & 37.46 & - & 0.08 & 0.04 & 0.33 & 0.30 & 7.35 & - & 0.49 & - & 93.13 & 3.11 & 0.89 & 2.03 & 0.00 & 0.00 & 0.00 & 0.02 & 0.00 & 0.03 & 0.62 & 0.06 & 0.00 & 0.00 & 4.00 & 2.09 & 0.68 & 6.77 \\
\hline \multicolumn{30}{|l|}{ Tension gashes } \\
\hline SEM39-c1-1 & 47.5 & 37.56 & 0.08 & 0.05 & - & 0.42 & 0.35 & 6.86 & 0.10 & 0.37 & 0.15 & 93.52 & 3.12 & 0.00 & 2.03 & 0.00 & 0.00 & 0.00 & 0.02 & 0.00 & 0.05 & 0.57 & 0.05 & 0.01 & 0.00 & 4.00 & 2.09 & 0.64 & 6.73 \\
\hline
\end{tabular}


SEM39-c1-2 $46.3 \quad 37.23 \quad 0.06 \quad 0.04 \quad-$ SEM39-c1-3 46.737 .33 - 0.03 $\begin{array}{llllll}\text { SEM39-c1-5 } & 46.9 & 37.08 & 0.16 & 0.04 & -\end{array}$ $\begin{array}{llllll} & \text { SEM39-c1-8 } 46.736 .82 & - & 0.04 & -\end{array}$ SEM39-c1-9 $46.337 .07-0.04$ SEM39-c2-1 46.537 .31 - 0.04 SEM39-c2-3 47.937 .53 - 0.04 SEM39-c2-4 $47.2 \quad 37.32 \quad 0.10 \quad 0.06 \quad-$ SEM39-c2-7 47.837 .24 - 0.06 SEM39-c3-3 47.036 .82 - $0.05-$ SEM42-c3-2 $46.7 \quad 36.77 \quad 0.08 \quad 0.04$

Wallrock between vein \& slates

$\begin{array}{lllll}\text { LS2-c3-1 } & 46.5 & 36.73 & 0.07 & 0.04\end{array}$

Deformed vein in slate

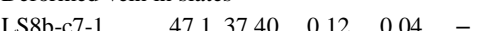

$\begin{array}{llllll}\text { LS8b-c7-2 } & 47.2 & 37.33 & - & 0.04 & -\end{array}$

LS8b-c6-2 $\quad 47.136 .90 \quad 0.17 \quad 0.03 \quad-$

LS 8 b-c5-8 $\begin{array}{lll}47.0 & 35.95 \quad 0.10\end{array}$

Dolerite

$\begin{array}{llllll}\text { SEM45-c1-1 } & 46.3 & 36.69 & 0.79 & 0.08 & -\end{array}$ $\begin{array}{lllll}\text { SEM45-c5-1 } & 46.3 & 36.75 & 0.09 & 0.08\end{array}$ $\begin{array}{llllll}\text { SEM45-c5-2 } & 46.9 & 36.82 & 0.24 & 0.07 & -\end{array}$ $\begin{array}{llllll}\text { SEM45-c5-3 } & 47.5 & 37.44 & 0.13 & 0.05 & -\end{array}$

$\begin{array}{lllllll}\text { Average } & 47.136 .88 & 0.12 & 0.07 & 0.04\end{array}$

$\begin{array}{lllllll}\text { Stdev } & 5.9 & 4.66 & 0.11 & 0.02 & 0.01\end{array}$

$\begin{array}{lll}0.11 & 0.06 & 0.99\end{array}$

Allophane

D.L. $\begin{array}{lllll}0.04 & 0.04 & 0.06 & 0.03 & 0.02\end{array}$

$\begin{array}{lll}0.06 & 0.02 & 0.03\end{array}$

Around Apy in slates

37.545 .74 - -

$\begin{array}{llll}\text { LS2-c2-1 } & 36.946 .13 & - & \text { bdl } \\ \text { 36. } 46.54 & - & \text { bdl }\end{array}$

LS2-c2-2 36.246 .38 bdl bdl

Mineralized vein in contact with stibnite SEM42-c1-2 36.046 .65 bdl $-\quad$ bdl SEM42-c1-3 36.146 .84 bdl bdl bdl SEM42-c1-6 $34.645 .54-0.03$ bdl SEM42-c2-1 36.447 .78 bdl bdl bdl SEM42-c2-2 36.747 .24 bdl 0.03 bdl $\begin{array}{lllll}\text { Average } & 36.3 & 46.56 & 0.03\end{array}$ Stdev \begin{tabular}{ll}
$0.7 \quad 0.67$ \\
\hline
\end{tabular} 0.01 $\begin{array}{lllllll}1.15 & 0.37 \mathrm{bdl} & 0.18 \mathrm{bdl} & \text { bdl } & 84.96 \\ 0.76 & 0.28 & 0.03 & 0.21 & \mathrm{bdl} & - & 84.52\end{array}$ $\begin{array}{lllllll}0.76 & 0.28 & 0.03 & 0.21 & \text { bdl } & - & 84.52\end{array}$ $\begin{array}{lllllll}0.26 & 0.08 & 0.05 & 0.25 & 0.05 & \text { bdl } & 83.52\end{array}$ $\begin{array}{llllll}0.52 & 0.28 & 0.03 & 0.17 \mathrm{bdl} & - & 83.72\end{array}$

$0.32 \quad 0.12$ bdl 0.21 bdl bdl 83.92 $\begin{array}{llllll}0.20 & 0.14 & 0.03 & 0.13 \mathrm{bdl} & - & 83.25\end{array}$ $\begin{array}{lllll}0.31 & 0.08- & 0.11 \text { bdl } & - & 83.51\end{array}$ $0.130 .10-\quad 0.10$ bdl bdl 80.58 $\begin{array}{llll}0.17 & 0.12-0.07 \text { bdl } & - & 84.67\end{array}$ $\begin{array}{llll}0.30 & 0.13- & 0.16 \text { bdl bdl } 84.63\end{array}$ $\begin{array}{lllllll}0.30 & 0.13- & 0.16 & \text { bdl } & \text { bdl } & 84.63 \\ 0.41 & 0.17 & 0.04 & 0.16 & 0.05 & & 83.73\end{array}$ $\begin{array}{lllllll}0.41 & 0.17 & 0.04 & 0.16 & 0.05 & 83.73 \\ 0.32 & 0.10 & 0.02 & 0.05 & 0.02 & 1.25\end{array}$

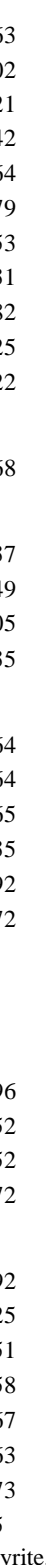


Appendix A.5

Electron microprobe analyses of sulfides from mineralization of the Semnon Sb-Au deposit.

\begin{tabular}{|c|c|c|c|c|c|c|c|c|c|c|c|c|c|}
\hline Element & $\mathrm{S} \%$ & $\mathrm{Fe} \%$ & As $\%$ & $\mathrm{Sb} \%$ & $\mathrm{Au} \%$ & $\mathrm{Bi} \%$ & $\mathrm{Zn} \%$ & $\mathrm{Cu} \%$ & Co $\%$ & $\mathrm{Ni} \%$ & $\mathrm{Ag} \%$ & $\mathrm{Se} \%$ & Total \\
\hline \multicolumn{14}{|l|}{ Arsenopyrite } \\
\hline D.L. & 0.12 & 0.07 & 0.07 & 0.09 & 0.08 & 0.16 & 0.11 & 0.18 & 0.06 & 0.06 & 0.12 & 0.06 & \\
\hline LS2-Tr-c1-1 & 21.16 & 34.23 & 43.55 & 0.26 & - & 0.03 & - & - & - & 0.27 & bdl & - & 99.54 \\
\hline LS2-Tr-c1-1 & 21.31 & 34.57 & 43.27 & 0.34 & bdl & - & bdl & bdl & - & - & - & - & 99.56 \\
\hline LS2-Tr-c1-1 & 21.26 & 34.57 & 43.02 & 0.33 & - & - & - & bdl & - & - & - & - & 99.21 \\
\hline LS2-Tr-c1-1 & 21.27 & 34.19 & 42.87 & 0.34 & - & - & bdl & bdl & - & - & - & - & 98.71 \\
\hline LS2-Tr-c1-1 & 21.17 & 34.01 & 42.77 & - & - & 0.04 & bdl & bdl & - & - & bdl & - & 98.12 \\
\hline LS2-Tr-c1-1 & 21.17 & 34.47 & 42.85 & 0.33 & bdl & 0.02 & - & - & - & - & bdl & - & 98.92 \\
\hline LS2-Tr-c1-1 & 21.06 & 34.95 & 43.09 & 0.34 & bdl & - & - & bdl & - & - & - & - & 99.50 \\
\hline LS2-Tr-c1-1 & 21.73 & 34.47 & 42.91 & 0.21 & bdl & - & bdl & - & - & - & bdl & - & 99.42 \\
\hline LS2-Tr-c1-1 & 21.33 & 34.62 & 43.02 & 0.26 & - & - & - & bdl & - & - & bdl & - & 99.27 \\
\hline LS2-Tr-c1-1 & 21.21 & 34.31 & 43.03 & 0.26 & bdl & - & bdl & - & - & - & bdl & - & 98.92 \\
\hline LS2-Tr-c1-1 & 21.43 & 34.56 & 42.74 & 0.40 & bdl & 0.03 & bdl & bdl & - & - & - & - & 99.21 \\
\hline LS2-Tr-c1-1 & 21.06 & 34.73 & 43.03 & 0.67 & - & - & bdl & bdl & - & - & bdl & - & 99.59 \\
\hline LS2-Tr-c1-1 & 22.15 & 34.58 & 41.13 & 1.23 & - & - & - & bdl & - & 0.10 & - & - & 99.25 \\
\hline LS2-Tr-c1-1 & 20.87 & 34.21 & 42.89 & 0.86 & bdl & - & - & bdl & - & - & bdl & - & 98.98 \\
\hline LS2-Tr-c1-1 & 21.69 & 34.26 & 42.57 & 0.17 & - & 0.03 & - & bdl & - & - & bdl & - & 98.83 \\
\hline LS2-Tr-c1-1 & 20.92 & 34.29 & 43.16 & 0.39 & - & - & - & - & - & - & bdl & - & 98.80 \\
\hline LS2-Tr-c1-1 & 20.97 & 33.96 & 42.76 & 0.35 & - & 0.05 & bdl & bdl & - & - & bdl & - & 98.28 \\
\hline LS2-Tr-c1-1 & 21.07 & 34.61 & 43.32 & 0.56 & - & - & - & - & - & - & bdl & - & 99.60 \\
\hline LS2-Tr-c1-1 & 20.84 & 34.61 & 43.33 & 0.34 & bdl & - & - & - & - & - & bdl & - & 99.18 \\
\hline LS2-Tr-c1-1 & 20.99 & 34.35 & 42.83 & 0.47 & bdl & 0.01 & bdl & bdl & - & - & - & - & 98.79 \\
\hline LS2-Tr-c1-1 & 21.51 & 34.67 & 42.84 & 0.43 & bdl & - & bdl & bdl & - & - & - & - & 99.60 \\
\hline LS2-Tr-c1-1 & 21.07 & 34.64 & 43.34 & 0.19 & - & - & bdl & bdl & - & - & bdl & - & 99.41 \\
\hline LS2-Tr-c1-1 & 20.84 & 33.89 & 43.37 & 0.31 & bdl & - & - & bdl & - & - & bdl & - & 98.51 \\
\hline LS2-Tr-c1-1 & 21.34 & 34.09 & 42.96 & 0.10 & - & 0.01 & - & bdl & - & - & - & - & 98.52 \\
\hline LS2-Tr-c1-1 & 21.20 & 34.52 & 43.10 & 0.31 & - & - & bdl & bdl & - & - & - & - & 99.22 \\
\hline LS2-Tr-c1-1 & 20.75 & 34.37 & 43.39 & 0.21 & bdl & - & - & bdl & - & - & bdl & - & 98.79 \\
\hline LS2-Tr-c1-1 & 20.61 & 33.96 & 42.95 & 0.37 & bdl & 0.05 & - & bdl & - & - & - & - & 98.03 \\
\hline LS2-Tr-c1-1 & 21.15 & 34.78 & 43.20 & 0.41 & bdl & - & - & bdl & - & - & bdl & - & 99.62 \\
\hline LS2-Tr-c1-1 & 20.91 & 34.26 & 43.10 & 0.10 & bdl & - & bdl & - & - & 0.14 & - & - & 98.55 \\
\hline LS2-Tr-c1-1 & 21.08 & 34.30 & 43.25 & 0.30 & bdl & - & - & bdl & - & - & bdl & - & 99.05 \\
\hline LS2-Tr-c1-1 & 21.21 & 34.50 & 43.41 & - & - & - & bdl & - & - & - & bdl & - & 99.14 \\
\hline LS2-Tr-c1-1 & 21.19 & 34.28 & 42.87 & 0.38 & - & 0.01 & - & - & - & - & bdl & - & 98.83 \\
\hline LS2-Tr-c1-1 & 21.06 & 34.61 & 43.03 & 0.29 & bdl & - & bdl & - & - & - & - & - & 99.02 \\
\hline LS2-Tr-c1-1 & 21.73 & 34.39 & 41.60 & 1.22 & - & 0.08 & - & bdl & - & - & - & - & 99.07 \\
\hline LS2-Tr-c1-1 & 21.04 & 34.56 & 43.29 & 0.53 & - & - & bdl & bdl & - & - & bdl & - & 99.60 \\
\hline LS2-Tr-c1-1 & 21.03 & 34.29 & 43.17 & 0.51 & bdl & 0.04 & - & - & - & - & - & - & 99.04 \\
\hline LS2-Tr-c1-1 & 21.09 & 34.15 & 42.78 & 0.60 & bdl & - & bdl & bdl & - & - & - & - & 98.70 \\
\hline LS2-Tr-c1-1 & 20.80 & 34.08 & 43.22 & 0.33 & - & - & bdl & - & - & - & bdl & - & 98.46 \\
\hline LS2-Tr-c1-1 & 20.85 & 34.19 & 43.41 & 0.31 & - & - & - & bdl & - & - & bdl & - & 98.86 \\
\hline LS2-Tr-c1-1 & 20.69 & 34.42 & 43.18 & 0.88 & - & - & - & bdl & - & - & bdl & - & 99.20 \\
\hline LS2-Tr-c1-1 & 21.47 & 34.64 & 43.02 & 0.29 & - & - & - & bdl & - & - & bdl & - & 99.56 \\
\hline LS2-Tr-c1-1 & 21.28 & 34.43 & 43.08 & 0.18 & - & - & bdl & bdl & - & - & - & - & 99.02 \\
\hline LS2-Tr-c1-1 & 21.34 & 33.94 & 42.97 & 0.56 & - & - & bdl & bdl & - & 0.09 & bdl & - & 98.93 \\
\hline LS2-Tr-c1-1 & 21.04 & 33.94 & 42.95 & 0.26 & - & - & bdl & bdl & - & - & bdl & - & 98.41 \\
\hline LS2-Tr-c1-2 & 21.29 & 34.11 & 43.24 & 0.24 & bdl & - & bdl & - & - & - & - & - & 98.95 \\
\hline
\end{tabular}




\begin{tabular}{|c|c|c|c|c|c|c|c|c|c|c|c|c|c|c|}
\hline$\underset{1 \mathrm{~L} 2 \mathrm{Tr}-\mathrm{Cl} \cdot \mathrm{T}}{\mathrm{LS}-\mathrm{c} 1-2}$ & 21.11 & 33.87 & 43.40 & 0.11 & $=$ & $=$ & bdl & bdl & $=$ & 0.13 & $\overline{\text { ball }}$ & - & 98.67 & \\
\hline LS2-Tr-c1-2 & 20.96 & 34.33 & 43.44 & 0.29 & - & 0.02 & bdl & - & - & - & - & - & 99.05 & \\
\hline LS2-Tr-c1-2 & 21.55 & 33.99 & 42.71 & 0.59 & - & - & bdl & - & - & - & - & - & 98.91 & -0 \\
\hline LS2-Tr-c1-2 & 21.56 & 34.62 & 42.80 & 0.17 & - & - & - & bdl & - & - & - & - & 99.21 & \\
\hline LS2-Tr-c1-2 & 21.08 & 34.02 & 43.14 & 0.21 & - & - & bdl & bdl & - & - & - & - & 98.66 & \\
\hline LS2-Tr-c1-2 & 20.96 & 34.24 & 43.11 & 0.30 & - & - & - & bdl & - & - & bdl & - & 98.69 & \\
\hline LS2-Tr-c1-2 & 20.90 & 34.21 & 43.32 & 0.25 & - & - & - & bdl & - & - & - & - & 98.71 & \\
\hline LS2-Tr-c1-2 & 21.29 & 34.24 & 43.18 & 0.38 & - & - & - & bdl & - & - & bdl & - & 99.18 & \\
\hline LS2-Tr-c1-2 & 21.44 & 34.36 & 42.92 & 0.42 & - & - & - & bdl & - & - & bdl & - & 99.31 & \\
\hline LS2-Tr-c1-2 & 21.06 & 34.04 & 43.32 & 0.14 & - & 0.01 & - & bdl & - & - & bdl & - & 98.65 & \\
\hline LS2-Tr-c1-2 & 20.83 & 34.16 & 43.23 & 0.38 & - & - & - & bdl & - & - & - & - & 98.64 & \\
\hline LS2-Tr-c1-2 & 21.21 & 34.04 & 43.16 & 0.41 & bdl & - & bdl & bdl & - & - & bdl & - & 98.94 & \\
\hline LS2-Tr-c1-2 & 21.07 & 34.14 & 43.02 & 0.19 & - & - & bdl & bdl & - & - & bdl & - & 98.57 & \\
\hline LS2-Tr-c1-2 & 21.67 & 34.17 & 42.73 & 0.11 & bdl & - & - & - & - & 0.09 & - & - & 98.84 & \\
\hline LS2-Tr-c1-2 & 21.62 & 34.27 & 41.96 & 0.20 & - & - & - & bdl & - & - & - & - & 98.10 & \\
\hline LS2-Pt-c1-3 & 21.08 & 33.74 & 43.23 & 0.21 & - & - & - & bdl & - & - & bdl & - & 98.40 & \\
\hline LS2-Pt-c2-12 & 21.44 & 34.09 & 43.22 & 0.20 & - & - & - & - & - & - & - & - & 99.02 & \\
\hline LS8b-Tr-hc-14 & 21.36 & 34.62 & 43.05 & 0.16 & bdl & 0.05 & bdl & - & - & - & bdl & - & 99.35 & \\
\hline LS8b-Tr-hc-14 & 21.05 & 34.91 & 43.08 & 0.10 & - & - & - & bdl & - & - & bdl & - & 99.21 & \\
\hline LS8b-Tr-hc-14 & 20.82 & 34.42 & 43.30 & - & - & - & - & bdl & - & - & - & - & 98.60 & \\
\hline LS8b-Tr-hc-14 & 21.06 & 34.53 & 42.87 & - & bdl & - & bdl & bdl & - & - & bdl & - & 98.59 & \\
\hline LS8b-Tr-hc-14 & 21.78 & 34.65 & 42.74 & - & - & - & - & bdl & - & 0.10 & bdl & - & 99.33 & \\
\hline LS8b-Tr-hc-14 & 21.94 & 34.73 & 42.72 & - & - & - & bdl & bdl & - & - & bdl & - & 99.58 & \\
\hline LS8b-Tr-hc-14 & 21.88 & 34.84 & 42.61 & 0.28 & - & 0.01 & - & bdl & - & - & bdl & - & 99.68 & \\
\hline LS8b-Tr-hc-14 & 21.90 & 34.66 & 42.51 & 0.13 & - & - & - & - & - & - & - & - & 99.20 & \\
\hline LS8b-Tr-hc-14 & 21.54 & 34.54 & 42.76 & 0.15 & bdl & - & bdl & - & - & - & bdl & - & 99.08 & \\
\hline LS8b-Tr-hc-14 & 21.74 & 34.92 & 42.45 & 0.17 & - & - & - & bdl & - & - & bdl & - & 99.37 & \\
\hline LS8b-Tr-hc-14 & 22.00 & 34.91 & 42.45 & 0.11 & - & 0.02 & - & - & - & - & - & - & 99.50 & \\
\hline LS8b-Tr-hc-14 & 21.69 & 34.45 & 39.17 & 0.16 & - & - & - & bdl & - & - & - & - & 95.59 & \\
\hline LS8b-Tr-hc-14 & 21.61 & 34.66 & 42.37 & 0.35 & - & - & - & bdl & - & - & - & - & 99.01 & \\
\hline LS8b-Tr-hc-14 & 21.63 & 34.50 & 42.65 & 0.11 & - & 0.02 & bdl & bdl & - & - & bdl & - & 99.10 & \\
\hline LS8b-Tr-hc-14 & 21.31 & 34.46 & 42.67 & 0.25 & - & 0.06 & - & bdl & 0.09 & 0.19 & - & - & 99.05 & \\
\hline LS8b-Tr-hc-14 & 21.44 & 34.79 & 42.50 & 0.25 & - & 0.02 & bdl & - & - & - & - & - & 99.05 & \\
\hline LS8b-Tr-hc-14 & 21.71 & 34.62 & 42.78 & 0.19 & - & - & - & bdl & - & - & bdl & - & 99.43 & \\
\hline LS8b-Tr-hc-14 & 21.38 & 34.23 & 43.00 & 0.13 & - & - & - & bdl & - & 0.13 & bdl & - & 98.92 & \\
\hline LS8b-Tr-hc-14 & 21.24 & 34.59 & 43.14 & 0.20 & bdl & - & - & bdl & - & 0.20 & bdl & - & 99.48 & \\
\hline LS8b-Tr-hc-14 & 21.21 & 34.45 & 43.09 & 0.87 & bdl & 0.08 & bdl & bdl & - & - & bdl & - & 99.93 & \\
\hline LS8b-Tr-hc-14 & 21.40 & 34.81 & 42.65 & 0.69 & - & - & - & - & - & - & bdl & - & 99.57 & \\
\hline LS8b-Tr-hc-14 & 21.37 & 34.52 & 42.98 & 0.39 & - & - & - & - & - & - & bdl & - & 99.28 & \\
\hline LS8b-Tr-hc-14 & 20.95 & 34.51 & 43.28 & 0.45 & - & 0.03 & - & - & - & - & bdl & - & 99.25 & \\
\hline LS8b-Tr-hc-14 & 20.81 & 34.28 & 43.27 & 0.48 & - & - & bdl & bdl & - & - & bdl & - & 98.93 & 0 요 \\
\hline LS8b-Tr-hc-14 & 20.77 & 34.27 & 43.28 & 0.44 & - & - & - & - & - & - & bdl & - & 98.83 & \\
\hline LS8b-Tr-hc-14 & 20.84 & 34.49 & 43.17 & 0.44 & - & - & - & bdl & - & - & bdl & - & 99.04 & \\
\hline LS8b-Tr-hc-14 & 21.32 & 34.34 & 43.15 & 0.50 & - & - & bdl & bdl & - & - & - & - & 99.38 & \\
\hline LS8b-Tr-hc-14 & 21.11 & 34.52 & 43.03 & 0.42 & - & - & - & - & - & - & bdl & - & 99.10 & $\omega \leqslant \bar{\sigma}$ \\
\hline LS8b-Tr-hc-14 & 21.24 & 34.42 & 43.36 & 0.51 & - & - & - & bdl & - & - & bdl & - & 99.59 & \\
\hline LS8b-Tr-hc-14 & 21.35 & 34.64 & 42.96 & 0.43 & - & - & - & - & - & - & - & - & 99.41 & -icn \\
\hline LS8b-Tr-hc-14 & 20.51 & 34.32 & 43.37 & 0.31 & - & 0.01 & bdl & - & - & - & - & - & 98.53 & $\ldots$ \\
\hline LS8b-Tr-hc-14 & 21.47 & 34.47 & 42.72 & 0.59 & bdl & - & bdl & - & - & - & bdl & - & 99.33 & \\
\hline LS8b-Tr-hc-14 & 21.31 & 34.60 & 42.34 & 0.96 & bdl & - & - & bdl & - & - & - & - & 99.24 & $0 \overrightarrow{0}$ \\
\hline LS8b-Tr-hc-14 & 21.29 & 34.26 & 42.21 & 1.01 & bdl & - & - & bdl & - & - & bdl & - & 98.85 & \\
\hline
\end{tabular}




\begin{tabular}{|c|c|c|c|c|c|c|c|c|c|c|c|c|c|c|}
\hline LSS8b-Tr-hc-14 & 21.37 & 33.96 & 42.33 & 1.00 & $\overline{\text { ball }}$ & $\overline{0.02}$ & $\overline{-}$ & $\underset{\text { bdll }}{\text { bdl }}$ & $\overline{-}$ & 0.10 & $\underline{b d l}$ & $\overline{-}$ & 98.87 & \\
\hline LS8b-Tr-hc-14 & 21.94 & 34.61 & 41.69 & 0.66 & - & 0.01 & bdl & bdl & - & - & bdl & - & 99.04 & \\
\hline LS8b-Tr-hc-14 & 21.53 & 34.55 & 41.92 & 0.66 & - & - & - & - & - & - & - & - & 98.68 & -0 \\
\hline LS8b-Tr-hc-14 & 22.01 & 34.67 & 42.07 & 0.58 & - & - & bdl & bdl & - & - & - & - & 99.36 & \\
\hline LS8b-Tr-hc-14 & 21.42 & 34.53 & 42.03 & 0.68 & bdl & - & bdl & bdl & - & - & bdl & - & 98.81 & \\
\hline LS8b-Tr-hc-14 & 22.01 & 34.53 & 41.70 & 0.62 & - & - & - & bdl & - & - & bdl & - & 98.97 & \\
\hline LS8b-Tr-hc-14 & 21.56 & 34.52 & 42.23 & 0.30 & - & - & bdl & bdl & - & - & - & - & 98.68 & \\
\hline LS8b-Tr-hc-14 & 22.15 & 34.53 & 41.95 & 0.19 & - & - & - & bdl & - & - & bdl & - & 98.88 & \\
\hline LS8b-Tr-hc-15 & 21.52 & 34.40 & 42.75 & 0.12 & - & 0.02 & - & - & - & - & - & - & 98.82 & \\
\hline LS8b-Tr-hc-15 & 21.17 & 34.54 & 43.06 & 0.10 & - & 0.02 & - & - & - & - & - & - & 98.90 & \\
\hline LS8b-Tr-hc-15 & 18.54 & 33.58 & 46.60 & - & - & - & - & bdl & - & - & bdl & - & 98.84 & \\
\hline LS8b-Tr-hc-15 & 21.83 & 34.41 & 42.53 & 0.11 & - & - & bdl & - & - & - & bdl & - & 99.01 & \\
\hline LS8b-Tr-hc-15 & 21.71 & 34.59 & 42.34 & 0.14 & - & - & - & - & - & - & - & - & 98.84 & \\
\hline LS8b-Tr-hc-15 & 21.50 & 34.45 & 42.88 & - & - & - & - & - & - & - & - & - & 98.91 & \\
\hline LS8b-Tr-hc-15 & 21.79 & 34.38 & 42.61 & - & bdl & - & - & bdl & - & - & bdl & - & 98.94 & \\
\hline LS8b-Tr-hc-15 & 21.80 & 34.37 & 42.46 & 0.19 & bdl & - & - & bdl & - & 0.09 & - & - & 99.04 & \\
\hline LS8b-Tr-hc-15 & 21.90 & 34.45 & 42.43 & - & - & - & bdl & - & - & 0.17 & bdl & - & 99.11 & \\
\hline LS8b-Tr-hc-15 & 21.85 & 34.66 & 41.74 & 0.24 & - & 0.01 & bdl & bdl & - & - & bdl & - & 98.62 & \\
\hline LS8b-Tr-hc-15 & 22.08 & 34.65 & 41.51 & - & - & - & bdl & - & - & 0.08 & bdl & - & 98.41 & \\
\hline LS8b-Tr-hc-15 & 22.03 & 34.45 & 42.05 & 0.17 & bdl & - & bdl & bdl & - & - & bdl & - & 98.83 & \\
\hline LS8b-Tr-hc-15 & 22.44 & 34.66 & 41.58 & - & - & - & - & bdl & - & 0.08 & - & - & 98.87 & \\
\hline LS8b-Tr-hc-15 & 21.58 & 33.99 & 42.76 & 0.16 & - & - & - & - & 0.15 & 0.60 & - & - & 99.24 & \\
\hline LS8b-Tr-hc-15 & 21.72 & 34.44 & 42.43 & 0.28 & - & - & bdl & bdl & - & - & - & - & 98.91 & \\
\hline LS8b-Tr-hc-15 & 21.53 & 34.07 & 42.33 & 0.18 & - & - & - & bdl & - & 0.39 & bdl & - & 98.61 & \\
\hline LS8b-Tr-hc-15 & 21.01 & 34.52 & 42.79 & 0.39 & - & 0.05 & - & bdl & - & 0.18 & bdl & - & 99.10 & \\
\hline LS8b-Tr-hc-15 & 21.70 & 34.23 & 41.73 & 1.01 & bdl & 0.02 & bdl & bdl & - & - & - & - & 98.80 & \\
\hline LS8b-Tr-hc-15 & 20.87 & 34.53 & 43.01 & 0.51 & - & - & - & - & - & - & - & - & 98.93 & \\
\hline LS8b-Tr-hc-15 & 20.85 & 34.11 & 42.61 & 0.48 & - & - & bdl & bdl & - & - & - & - & 98.18 & \\
\hline LS8b-Tr-hc-15 & 21.43 & 34.66 & 42.64 & 0.47 & bdl & - & bdl & bdl & - & - & bdl & - & 99.29 & \\
\hline LS8b-Tr-hc-15 & 21.09 & 34.51 & 43.25 & 0.46 & bdl & - & - & - & - & - & - & - & 99.32 & \\
\hline LS8b-Tr-hc-15 & 21.73 & 34.23 & 42.79 & 0.11 & - & - & - & - & - & - & - & - & 98.87 & \\
\hline LS8b-Tr-hc-15 & 21.29 & 34.51 & 42.62 & 0.54 & - & - & - & bdl & - & - & bdl & - & 99.06 & \\
\hline LS8b-Tr-hc-15 & 21.56 & 34.42 & 42.47 & 0.68 & - & - & - & bdl & - & - & - & - & 99.17 & \\
\hline LS8b-Tr-hc-15 & 21.59 & 34.67 & 42.71 & 0.76 & bdl & 0.01 & - & - & - & - & - & - & 99.80 & \\
\hline LS8b-Tr-hc-15 & 21.79 & 34.78 & 41.90 & 0.80 & bdl & - & bdl & bdl & - & - & bdl & - & 99.42 & \\
\hline LS8b-Tr-hc-15 & 21.25 & 34.52 & 42.59 & 0.61 & - & 0.09 & - & bdl & - & - & bdl & - & 99.13 & \\
\hline LS8b-Tr-hc-15 & 21.64 & 34.63 & 42.75 & - & - & - & bdl & - & - & 0.13 & - & - & 99.22 & \\
\hline LS8b-Tr-hc-15 & 21.22 & 34.79 & 43.03 & 0.18 & - & 0.01 & bdl & bdl & - & - & - & - & 99.26 & \\
\hline LS8b-Tr-hc-15 & 21.09 & 34.65 & 42.68 & 0.55 & - & - & bdl & bdl & - & - & bdl & - & 99.07 & \\
\hline LS8b-Tr-hc-15 & 21.19 & 34.85 & 42.72 & 0.34 & - & - & - & bdl & - & - & bdl & - & 99.20 & \\
\hline LS8b-Tr-hc-15 & 21.32 & 34.42 & 42.78 & 0.62 & - & - & bdl & bdl & - & - & bdl & - & 99.32 & 0 ? \\
\hline LS8b-Tr-hc-15 & 21.30 & 34.68 & 42.56 & 0.74 & - & - & - & bdl & - & - & - & - & 99.36 & \\
\hline LS8b-Tr-hc-15 & 21.24 & 34.67 & 42.29 & 0.27 & - & 0.02 & bdl & - & - & - & bdl & - & 98.57 & \\
\hline LS8b-Tr-hc-15 & 21.48 & 34.48 & 41.89 & 0.89 & - & - & - & bdl & - & 0.09 & bdl & - & 98.90 & \\
\hline LS8b-Tr-hc-15 & 21.56 & 34.65 & 41.76 & 0.69 & bdl & - & bdl & - & - & - & - & - & 98.76 & $\omega \leqslant \bar{\Phi}$ \\
\hline LS8b-Tr-hc-15 & 21.10 & 34.39 & 42.87 & 0.73 & - & 0.05 & bdl & bdl & - & - & - & - & 99.23 & \\
\hline LS8b-Tr-hc-15 & 21.56 & 34.37 & 41.82 & 0.50 & bdl & - & bdl & bdl & - & - & - & - & 98.34 & vicn \\
\hline LS8b-Tr-hc-15 & 21.28 & 34.61 & 42.57 & 0.58 & - & - & - & bdl & - & - & bdl & - & 99.14 & $\ldots$ \\
\hline LS8b-Tr-hc-15 & 21.50 & 34.49 & 42.40 & 0.61 & bdl & - & - & bdl & - & - & bdl & - & 99.08 & \\
\hline LS8b-Tr-hc-15 & 21.70 & 34.56 & 42.39 & 0.44 & - & - & - & bdl & - & - & bdl & - & 99.18 & $0 \overrightarrow{0}$ \\
\hline LS8b-Pt-hc-34 & 21.15 & 34.16 & 42.61 & 0.18 & - & - & - & bdl & - & - & - & - & 98.15 & \\
\hline
\end{tabular}




\begin{tabular}{|c|c|c|c|c|c|c|c|c|c|c|c|c|c|}
\hline 8A.z1.Apyb & 21.71 & 35.35 & 41.80 & - & 0.15 & - & - & - & - & - & - & 0.09 & 99.13 \\
\hline 8A.z1.Apybc & 21.38 & 35.49 & 42.63 & 0.04 & - & - & - & - & - & - & - & 0.07 & 99.60 \\
\hline 8A.z1.Apybc & 21.60 & 35.56 & 42.14 & 0.06 & - & 0.20 & - & - & - & - & - & - & 99.55 \\
\hline 8A.z1.Apybc & 21.70 & 35.73 & 42.85 & 0.08 & - & - & - & - & - & - & - & - & 100.36 \\
\hline 8A.z1.Apybc & 20.17 & 35.82 & 42.59 & 0.09 & - & - & - & - & - & - & - & 0.09 & 98.75 \\
\hline 8A.z1.Apybc & 21.69 & 35.61 & 42.13 & 0.14 & - & 0.22 & - & - & - & - & - & 0.11 & 99.90 \\
\hline 8A.z1.Apybc & 21.85 & 35.72 & 41.75 & 0.14 & - & - & - & - & - & 0.11 & - & 0.13 & 99.69 \\
\hline 8A.z1.Apybc & 21.62 & 35.68 & 41.96 & 0.52 & - & - & - & - & - & - & - & 0.13 & 99.91 \\
\hline 8A.z1.Apybc & 21.10 & 35.52 & 42.34 & 0.68 & - & 0.17 & - & - & - & - & - & - & 99.81 \\
\hline 8A.z1.Apybc & 21.85 & 35.69 & 41.87 & 0.57 & - & - & - & - & - & - & - & - & 99.98 \\
\hline 8A.z1.Apybc & 21.44 & 35.58 & 42.46 & 0.32 & - & - & - & - & - & - & - & - & 99.80 \\
\hline 8A.z1.Apybc & 21.37 & 35.63 & 42.42 & 0.28 & 0.09 & 0.12 & - & - & - & - & - & 0.13 & 100.05 \\
\hline 8A.z1.Apybc & 21.13 & 35.78 & 42.83 & 0.26 & - & - & - & - & - & - & - & 0.12 & 100.11 \\
\hline 8A.z1.Apybc & 21.12 & 35.38 & 42.30 & 0.20 & 0.16 & - & - & - & - & - & - & 0.10 & 99.25 \\
\hline 8A.z1.Apybc & 21.26 & 35.21 & 42.97 & 0.24 & - & - & - & - & - & - & - & 0.13 & 99.81 \\
\hline 8A.z1.Apybc & 21.25 & 35.03 & 42.58 & 0.35 & - & - & - & - & - & - & - & - & 99.22 \\
\hline 8A.z1.Apybc & 20.99 & 35.29 & 42.81 & 0.71 & - & 0.21 & - & - & - & 0.12 & - & - & 100.11 \\
\hline 8A.z1.Apybc & 21.30 & 35.83 & 43.05 & 0.23 & 0.10 & 0.15 & - & - & - & 0.12 & - & 0.07 & 100.84 \\
\hline 8A.z1.Apybc & 21.51 & 35.55 & 42.77 & 0.25 & - & - & - & - & - & 0.06 & - & 0.15 & 100.29 \\
\hline 8A.z1.Apybc & 21.74 & 35.70 & 42.14 & 0.24 & - & - & - & - & - & - & 0.07 & 0.07 & 99.95 \\
\hline 8A.z1.Apybc & 21.02 & 35.60 & 42.25 & 0.52 & - & - & - & - & - & - & - & 0.08 & 99.46 \\
\hline 8A.z1.Apybc & 21.90 & 35.72 & 42.35 & 0.27 & - & - & - & - & - & - & - & 0.06 & 100.30 \\
\hline 8A.z1.Apybc & 21.27 & 35.74 & 42.45 & 0.11 & 0.09 & 0.17 & - & - & - & - & - & 0.07 & 99.90 \\
\hline 8A.z1.Apybc & 21.34 & 35.66 & 42.69 & 0.08 & - & 0.11 & - & - & - & - & - & - & 99.89 \\
\hline 8A.z1.Apyb & 21.40 & 36.21 & 42.70 & - & 0.10 & 0.24 & - & - & - & - & - & 0.16 & 100.81 \\
\hline Average & 21.33 & 34.59 & 42.72 & 0.38 & - & 0.06 & - & - & 0.12 & 0.16 & - & 0.10 & 99.11 \\
\hline Stdev & 0.42 & 0.49 & 0.63 & 0.26 & - & 0.04 & - & - & 0.01 & 0.07 & - & 0.03 & 0.55 \\
\hline \multicolumn{14}{|l|}{ Pyrrhotite } \\
\hline SEM38-c1-2 & 39.36 & 58.93 & bdl & - & - & bdl & - & bdl & - & - & - & - & 98.43 \\
\hline SEM38-c1-4 & 39.34 & 59.13 & bdl & - & - & bdl & bdl & bdl & - & - & - & - & 98.68 \\
\hline SEM38-c1-5 & 38.99 & 58.93 & bdl & bdl & bdl & bdl & - & bdl & bdl & - & bdl & - & 98.15 \\
\hline SEM38-c1-7 & 39.09 & 59.80 & bdl & bdl & bdl & bdl & - & bdl & - & bdl & - & - & 99.17 \\
\hline SEM38-c1-10 & 39.61 & 59.36 & bdl & bdl & - & bdl & - & bdl & - & - & bdl & - & 99.22 \\
\hline SEM38-c1-14 & 39.33 & 59.42 & bdl & bdl & bdl & bdl & bdl & 0.21 & - & - & - & - & 99.09 \\
\hline SEM38-c1-15 & 39.76 & 58.32 & bdl & 0.19 & - & bdl & - & bdl & - & bdl & - & - & 98.49 \\
\hline Average & 39.35 & 59.13 & - & 0.19 & - & - & - & 0.21 & - & - & - & - & 98.75 \\
\hline Stdev & 0.27 & 0.47 & - & 0.07 & - & - & - & 0.08 & - & - & - & - & 0.42 \\
\hline \multicolumn{14}{|l|}{ Berthierite } \\
\hline LS2-Pt-hc-7 & 28.98 & 12.54 & 0.08 & 57.57 & - & bdl & - & bdl & - & - & bdl & - & 99.32 \\
\hline LS2-Pt-hc-11 & 27.81 & 3.26 & 0.09 & 68.36 & - & - & - & bdl & - & - & - & - & 99.57 \\
\hline SEM45-Pt-hc-39 & 29.13 & 15.30 & 3.76 & 53.04 & - & - & bdl & bdl & - & - & - & - & 101.39 \\
\hline SEM40-c1-1 & 29.74 & 12.75 & 0.11 & 57.74 & - & - & - & 0.22 & - & - & bdl & - & 100.58 \\
\hline SEM40-c1-4 & 29.45 & 12.86 & 0.10 & 57.65 & bdl & - & - & bdl & - & bdl & - & - & 100.24 \\
\hline SEM40-c1-5 & 29.78 & 12.90 & 0.12 & 57.77 & - & bdl & bdl & bdl & - & - & bdl & - & 100.75 \\
\hline SEM40-c1-6 & 29.32 & 12.84 & 0.10 & 57.49 & - & bdl & bdl & 0.26 & - & bdl & bdl & - & 100.12 \\
\hline SEM40-c1-8 & 29.89 & 12.71 & 0.07 & 57.70 & bdl & - & bdl & 0.20 & - & - & bdl & - & 100.60 \\
\hline SEM40-c2-1 & 29.51 & 12.66 & bdl & 57.68 & bdl & bdl & - & bdl & - & - & bdl & - & 99.97 \\
\hline SEM40-c2-3 & 29.53 & 12.92 & 0.09 & 57.66 & - & - & - & bdl & - & - & bdl & - & 100.33 \\
\hline SEM38-c1-16 & 30.30 & 13.12 & 0.11 & 54.48 & - & - & bdl & bdl & - & - & - & - & 98.15 \\
\hline Average & 29.40 & 12.17 & 0.46 & 57.92 & - & - & - & 0.22 & - & - & - & - & 100.09 \\
\hline Stdev & 0.64 & 3.05 & 1.11 & 3.81 & - & - & - & 0.11 & - & - & - & - & 0.86 \\
\hline
\end{tabular}


Stibnite

$\begin{array}{lllllll}\text { LS2-Pt-hc-5 } & 27.44 & 0.06 & \text { bdl } & 72.41 & \text { bdl } & - \\ \text { LS2-Pt-hc-6 } & 27.76 & 0.28 & - & 71.36 & - & - \\ \text { SEM42-Pt-c1-54 } & 27.99 & 0.01 & 0.13 & 72.76 & - & - \\ \text { SEM42-Pt-c1-55 } & 28.21 & 0.00 & 0.12 & 72.57 & \text { bdl } & \text { bdl } \\ \text { SEM42-Pt-hc-56 } & 27.97 & 0.00 & \text { bdl } & 72.58 & - & - \\ \text { SEM42-Pt-hc-57 } & 28.04 & 0.00 & 0.08 & 72.49 & \text { bdl } & - \\ \text { SEM40-c1-2 } & 27.76 & 0.21 & 0.08 & 72.58 & - & \text { bdl } \\ \text { SEM40-c1-3 } & 27.69 & 0.31 & 0.08 & 72.66 & \text { bdl } & - \\ \text { SEM40-c1-7 } & 27.63 & 0.09 & \text { bdl } & 71.56 & - & - \\ \text { SEM40-c2-2 } & 28.07 & 1.11 & \text { bdl } & 71.11 & \text { bdl } & - \\ \text { SEM40-c2-4 } & 27.99 & 0.05 & 0.09 & 71.83 & - & - \\ \text { SEM38-c1-1 } & 28.31 & 0.10 & \text { bdl } & 72.41 & - & \text { bdl } \\ \text { SEM38-c1-3 } & 27.38 & 0.27 & \text { bdl } & 70.85 & - & \text { bdl } \\ \text { SEM38-c1-8 } & 27.93 & 1.38 & \text { bdl } & 72.22 & \text { bdl } & - \\ \text { SEM38-c1-9 } & 28.38 & 0.45 & \text { bdl } & 72.11 & - & - \\ \text { SEM38-c1-11 } & 28.43 & 1.08 & \text { bdl } & 71.80 & - & - \\ \text { SEM38-c1-12 } & 28.34 & 0.43 & \text { bdl } & 72.42 & - & \text { bdl } \\ \text { SEM38-c1-13 } & 27.75 & 0.08 & \text { bdl } & 71.14 & - & - \\ \text { Average } & 27.95 & 0.33 & 0.10 & 72.05 & - & - \\ \text { Stdev } & 0.31 & 0.42 & 0.05 & 0.61 & - & -\end{array}$

Abbreviations: D.L., detection limit; Stdev, standard deviation; bdl, below detection limit; Apy, arsenopyrite; Stb, stibnite 


\section{Appendix A.6}

Estimated crystallization temperatures of arsenopyrite formed at As-Fe-Au-Sb stage based on the projection of as activity (Kretschmar and Scott, 1976; Sharp et al., 1985)

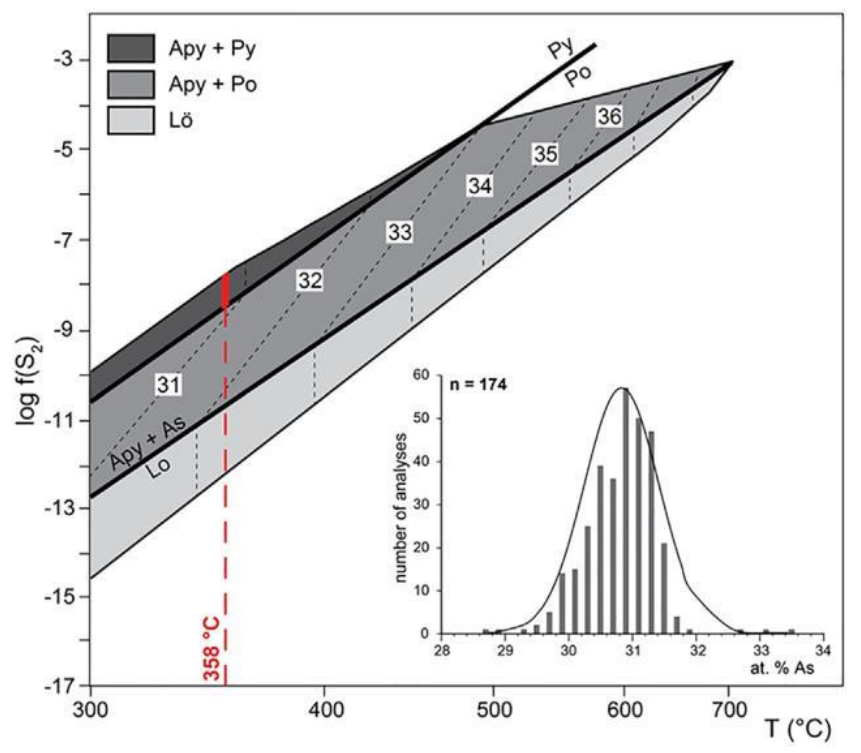

\section{Appendix A.7}

Chemical composition of representative aqueous-carbonic inclusions of the Le Semnon Sb-Au deposit obtained by Raman spectroscopy and corre-sponding microthermometric data.

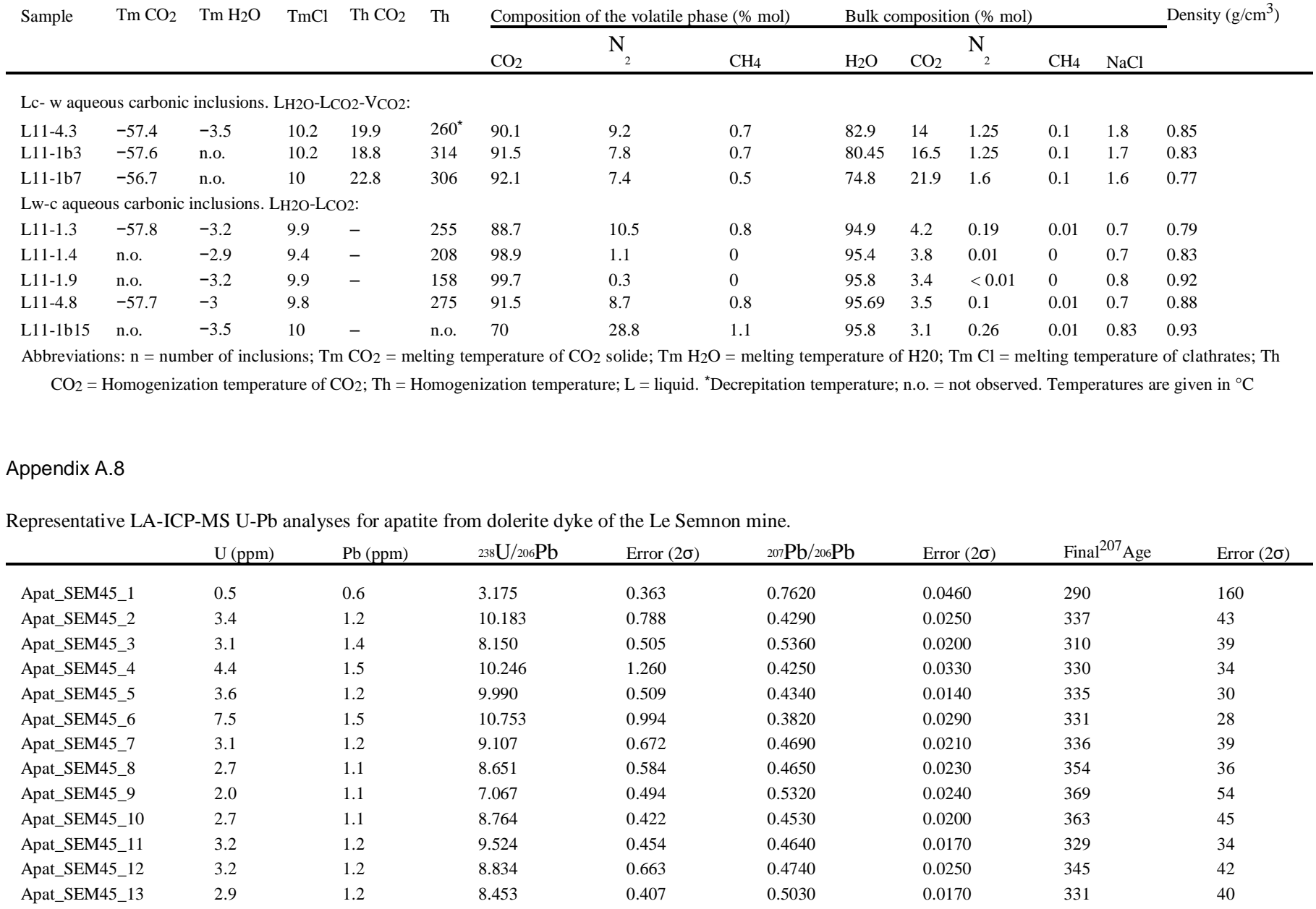




\begin{tabular}{|c|c|c|c|c|}
\hline Apat_SEM45_14 & 3.1 & 1.1 & 9.355 & 0.464 \\
\hline Apat_SEM45_15 & 2.8 & 1.0 & 9.050 & 0.475 \\
\hline Apat_SEM45_16 & 2.3 & 3.8 & 2.349 & 0.160 \\
\hline Apat_SEM45_17 & 2.6 & 1.2 & 7.806 & 0.506 \\
\hline Apat_SEM45_18 & 2.4 & 1.0 & 9.785 & 0.881 \\
\hline Apat_SEM45_19 & 2.2 & 0.8 & 8.811 & 0.481 \\
\hline Apat_SEM45_20 & 2.5 & 0.9 & 9.208 & 0.483 \\
\hline Apat_SEM45_21 & 3.4 & 1.1 & 9.940 & 0.563 \\
\hline Apat_SEM45_22 & 3.9 & 1.6 & 8.389 & 0.845 \\
\hline ApatSEM11_9_1 & 2.7 & 1.2 & 7.813 & 0.854 \\
\hline ApatSEM11_9_2 & 2.0 & 1.0 & 6.173 & 0.724 \\
\hline ApatSEM11_9_3 & 1.6 & 0.8 & 6.061 & 1.102 \\
\hline ApatSEM11_9_4 & 2.4 & 1.0 & 8.628 & 0.819 \\
\hline ApatSEM11_9_5 & 2.5 & 0.9 & 8.410 & 0.849 \\
\hline ApatSEM11_9_6 & 3.0 & 1.1 & 8.688 & 0.830 \\
\hline ApatSEM11_9_7 & 2.1 & 0.9 & 7.862 & 0.803 \\
\hline ApatSEM11_9_8 & 2.6 & 1.2 & 6.667 & 0.978 \\
\hline ApatSEM11_9_9 & 2.8 & 1.2 & 7.868 & 0.867 \\
\hline ApatSEM11_9_11 & 2.4 & 1.0 & 7.862 & 0.865 \\
\hline ApatSEM11_9_12 & 2.2 & 0.8 & 8.598 & 0.813 \\
\hline ApatSEM11_9_13 & 2.0 & 0.8 & 8.292 & 0.756 \\
\hline ApatSEM11_9_14 & 2.0 & 0.8 & 8.584 & 0.810 \\
\hline ApatSEM11_9_15 & 2.5 & 0.8 & 9.588 & 1.747 \\
\hline ApatSEM11_9_16 & 2.5 & 0.9 & 8.985 & 0.888 \\
\hline ApatSEM11_9_17 & 1.3 & 0.7 & 6.780 & 0.643 \\
\hline ApatSEM11_9_18 & 2.2 & 0.9 & 8.850 & 0.940 \\
\hline ApatSEM11_9_19 & 2.1 & 0.9 & 7.886 & 0.746 \\
\hline ApatSEM11_9_20 & 2.7 & 1.0 & 9.042 & 0.899 \\
\hline
\end{tabular}

\section{References}

Bakker, R.J., 1999. Adaptation of the Bowers and Helgeson (1983) equation of state to the H2O-CO2-CH4-N2-NaCl system. Chem. Geol. 154, 225-236.

Bakker, R.J., 2003. F.L.U.I.D.S. Package 1, Computer programs for analysis of fluid inclusion data and for modelling bulk fluid properties. Chem. Geol. 194, 3-23.

Ballèvre, M., Bosse, V., Ducassou, C., Pitra, P., 2009. Paleozoic history of the Armorican Massif: Models for the tectonic evolution of the suture zones. C. R. Geosci. 341, 174201.

Ballèvre, M., Catalán, J.R.M., López-Carmona, A., Pitra, P., Abati, J., Fernández, R.D., Ducassou, C., Arenas, R., Bosse, V., Castiñeiras, P., Fernández-Suárez, J., Barreiro, J.G., Paquette, J.L., Peucat, J.J., Poujol, M., Ruffet, G., Sánchez Martínez, S., 2014. Correlation of the nappe stack in the Ibero-Armorican arc across the Bay of Biscay: a joint FrenchSpanish project. Geol. Soc. Spec. Publ. 405, 77-113.

Ballouard, C., Poujol, M., Boulvais, P., Zeh, A., 2017. Crustal recycling and juvenile ad-dition during lithospheric wrenching: The Pontivy-Rostrenen magmatic complex, Armorican Massif (France), Variscan belt. Gondwana. Res. 49, 222-247.

Ballouard, C., Poujol, M., Mercadier, J., Deloule, E., Boulvais, P., Cuney, M., Cathelineau, M., In Press. Uranium metallogenesis in the peraluminous leucogranites from the PontivyRostrenen magmatic complex (French Armorican Hercynian Belt): the result of long term oxidizing hydrothermal alteration during strike-slip deformation. Miner. Deposita, 10.1007/s00126-017-0761-5

Barton, P.B., 1971. The Fe-Sb-S system. Econ. Geol. 66, 121-132.

Barton, P.B., Skinner, B.J., 1979. Sulfide mineral stabilities. In: Barnes, H.L. (Ed.), Geochemistry of Hydrothermal ore Deposits. John Wiley, New York, pp. 278-403.

Bellot, J.P., Lerouge, C., Bailly, L., Bouchot, V., 2003. The Biards Sb-Au-bearing shear zone (Massif Central, France): an indicator of crustal-scale transcurrent tectonics guiding Late Variscan collapse. Econ. Geol. 98, 1427-1447.

Bierlein, F.P., Crowe, D.E., 2000. Phanerozoic orogenic lode gold deposits. Rev. Econ. Geol. 13, 103-139.

Bierlein, F.P., Maher, S., 2001. Orogenic disseminated gold in Phanerozoic fold belt-sexamples from Victoria Australia and elsewhere. Ore Geol. Rev. 18, 113-148.

Bierlein, F.P., Groves, D.I., Goldfarb, R.J., Dubé, B., 2006. Lithospheric controls on the formation of provinces hosting giant orogenic gold deposits. Miner. Deposita 40, 874886.

Boiron, M.C., Cathelineau, M., Trescases, J.J., 1989. Conditions of gold-bearing arseno-pyrite crystallization in the Villeranges Basin, Marche-Combrailles shear zone, France; a mineralogical and fluid inclusion study. Econ. Geol. 84, 1340-1362.

Boiron, M.C., Cathelineau, M., Dubessy, J., Bastoul, A.M., 1990. Fluids in Hercynian Au veins from the French Variscan belt. Mineral. Mag. 54, 231-243.

Boiron, M.C., Cathelineau, M., Essarraj, S., Lespinasse, M., Sellier, E., Poty, B., 1992. Identification of fluid inclusions in relation to their host microstructural domains in quartz by cathodoluminescence. Geochim. Cosmochim. Acta 56, 175-185.

Boiron, M.C., Cathelineau, M., Banks, D.A., Fourcade, S., Vallance, J., 2003. Mixing of metamorphic and surficial fluids during the uplift of the Hercynian upper crust: consequences for gold deposition. Chem. Geol. 194, 119-141.

Bosse, V., Féraud, G., Ruffet, G., Ballèvre, M., Peucat, J.-J., De Jong, K., 2000. Late

$\begin{array}{llll}0.4480 & 0.0140 & 346 & 34 \\ 0.4460 & 0.0170 & 360 & 38 \\ 0.7710 & 0.0200 & 301 & 150 \\ 0.4890 & 0.0210 & 368 & 41 \\ 0.4260 & 0.0270 & 345 & 40 \\ 0.4630 & 0.0200 & 353 & 43 \\ 0.4490 & 0.0160 & 346 & 37 \\ 0.4360 & 0.0180 & 335 & 36 \\ 0.4490 & 0.0340 & 382 & 42 \\ 0.453 & 0.031 & 403 & 47 \\ 0.479 & 0.039 & 473 & 87 \\ 0.553 & 0.07 & 400 & 130 \\ 0.448 & 0.023 & 371 & 28 \\ 0.472 & 0.031 & 359 & 39 \\ 0.466 & 0.022 & 347 & 27 \\ 0.511 & 0.036 & 364 & 47 \\ 0.525 & 0.054 & 380 & 62 \\ 0.487 & 0.026 & 368 & 28 \\ 0.465 & 0.045 & 411 & 64 \\ 0.474 & 0.025 & 355 & 34 \\ 0.445 & 0.02 & 390 & 24 \\ 0.426 & 0.021 & 395 & 27 \\ 0.381 & 0.029 & 390 & 24 \\ 0.443 & 0.019 & 363 & 24 \\ 0.563 & 0.033 & 345 & 53 \\ 0.457 & 0.019 & 360 & 34 \\ 0.506 & 0.017 & 355 & 24 \\ 0.43 & 0.024 & 372 & 30\end{array}$

Devonian subduction and early-orogenic exhumation of eclogite-facies rocks from the Champtoceaux Complex (Variscan belt, France). Geol. J. 35, 297-325.

Bosse, V., Féraud, G., Ballèvre, M., Peucat, J.-J., Corsini, M., 2005. Rb-Sr and 40Ar/39Ar ages in blueschists from the Ile de Groix (Armorican Massif, France): Implications for closure mechanisms in isotopic systems. Chem. Geol. 220, 21-45.

Bouchot, V., Ledru, P., Lerouge, C., Lescuyer, J.L., Milesi, J.P., 2005. 5: Late Variscan mineralizing systems related to orogenic processes: The French Massif Central. Ore Geol. Rev. 27, 169-197.

Boullier, A.M., Robert, F., 1992. Palaeoseismic events recorded in Archaean gold-quartz vein networks, Val d'Or, Abitibi Quebec. Canada. J. Struct. Geol. 14, 164-179.

Boutin, A., de Saint Blanquat, M., Poujol, M., Boulvais, P., de Parseval, P., Rouleau, C., Robert, J.F., 2015. Succession of Permian and Mesozoic metasomatic events in the eastern Pyrenees with emphasis on the Trimouns talc-chlorite deposit. Int. J. Earth Sci. 105, 747770.

Bowers, T.S., Helgeson, H.C., 1983. Calculation of the thermodynamic and geochemical consequences of nonideal mixing in the system $\mathrm{H} 2 \mathrm{O}-\mathrm{CO} 2-\mathrm{NaCl}$ on phase relations in geologic systems: Equation of state for $\mathrm{H} 2 \mathrm{O}-\mathrm{CO} 2-\mathrm{NaCl}$ fluids at high pressures and temperatures. Geochim. Cosmochim. Acta 47, 1247-1275.

Bril, H., Beaufort, D., 1989. Hydrothermal alteration and fluid circulation related to W, Au, and Sb vein mineralizations, Haut Allier, Massif Central. France. Econ. Geol. 84, 2237-2251.

Budzyń, B., Harlov, D.E., Williams, M.L., Jercinovic, M.J., 2011. Experimental determi-nation of stability relations between monazite, fluorapatite, allanite, and REE-epidote as a function of pressure, temperature, and fluid composition. Am. Mineral. 96, 1547-1567.

Castonguay, S., Ruffet, G., Tremblay, A., 2007. Dating polyphase deformation across low-grade metamorphic belts: An example based on ${ }^{40} \mathrm{Ar} /{ }^{39} \mathrm{Ar}$ muscovite age constraints from the southern Quebec Appalachians. Canada. Geol. Soc. Am. Bull. 119, 978-992.

Chantraine, J., Atran, A., Cavelier, C., 1996. Geological map of France, 1/1 000000. BRGM, Orléans.

Chauris, L., Houlgatte, E., Laforêt, C., Picot, P., 1985. Un district antimono-aurifère à gangue quartzo-carbonatée, Le Semnon (Ille-et-Vilaine, Massif Armoricain, France). Hercynica 1, $111-119$.

Chauris, L., Marcoux, E., 1994. Metallogeny of the Armorican Massif. In: Chantraine, J., Rolet, J., Santallier, D.S., Piqué, A., Keppie, J.D. (Eds.), Pre-Mesozoic Geology in France and Related Areas. Springer, Berlin Heidelberg, pp. 243-264.

Cheilletz, A., Ruffet, G., Marignac, C., Kolli, O., Gasquet, D., Féraud, G., Bouillin, J.P., 1999 ${ }^{40} \mathrm{Ar} /{ }^{39} \mathrm{Ar}$ dating of shear zones in the Variscan basement of Greater Kabilia (Algeria). Evidence of an Eo-Alpine event at $128 \mathrm{Ma}$ (Hauterivian-Barremian boundary): Geodynamic consequences. Tectonophysics 306, 97-116.

Chew, D.M., Petrus, J.A., Kamber, B.S., 2014. U-Pb LA-ICPMS dating using accessory mineral standards with variable common $\mathrm{Pb}$. Chem. Geol. 363, 185-199.

Chovan, M., Hurai, V., Sachan, H.K., Kantor, J., 1995. Origin of the fluids associated with granodiorite-hosted Sb-As-Au-W mineralization at Dúbrava (Nízke-Tatry Mts, Western Carpathians). Miner. Deposita 30, 48-54.

Clayton, R.E., Scrivener, R.C., Stanley, C.J., 1990. Mineralogical and preliminary fluid inclusion studies of lead-antimony mineralisation in north Cornwall. Proc. Ussher Soc. 7, 258-262. 
Cobbold, P.R., Rodigues, N., 2007. Seepage forces, important factors in the formation of horizontal hydraulic fractures and bedding-parallel fibrous veins ('beef' and 'cone-in-cone'). Geofluids 7, 313-322.

Cochrane, R., Spikings, R.A., Chew, D., Wotzlaw, J.-F., Chiaradia, M., Tyrrell, S., Schaltegger, U., Van der Lelij, R., 2014. High temperature $\left(>350{ }^{\circ} \mathrm{C}\right)$ thermo-chronology and mechanisms of $\mathrm{Pb}$ loss in apatite. Geochim. Cosmochim. Acta 127, 39-56.

Costa, S., Rey, P., 1995. Lower crustal rejuvenation and growth during post-thickening collapse: insights from a crustal cross section through a Variscan core complex. Geology 23, 905-908.

Couto, H., Roger, G., Moëlo, Y., Bril, H., 1990. Le district à antimoine-or Dúrico-Beirão (Portugal), évolution paragénétique et géochimique; implications méttalogéniques. Miner. Deposita 25, 569-581.

Cox, S.F., 1987. Antitaxial crack-seal vein microstructures and their relationships to displacement paths. J. Struct. Geol. 9, 79-787.

Cox, S.F., 1995. Faulting processes at high fluid pressures: an example of fault valve behavior from the Wattle Gully Fault, Victoria Australia. J. Geophys. Res. 100, 1284112859 .

Cox, S.F., Wall, V.J., Etheridge, M.A., Potter, T.F., 1991. Deformation and metamorphic processes in the formation of mesothermal vein-hosted gold deposits - examples from the Lachlan Fold Belt in central Victoria Australia. Ore Geol. Rev. 6, 391-423.

Cox, S.F., Knackstedt, M.A., Braun, J., 2001. Principles of structural control on perme-ability and fluid flow in hydrothermal systems. Rev. Econ. Geol. 14, 1-24.

Dill, H.G., 1985. Antimoniferous mineralization from the Mid-European Saxothuringian Zone, mineralogy, geology, geochemistry and ensialic origin. Geologische Rundschau 74, 447466.

Donnot, M., Guigues, J., Lulzac, Y., Magnien, A., Parfenoff, A., Picot, P., 1973. Un nou-veau type de gisement d'europium: la monazite grise à europium en nodules dans les schistes paléozoïques de Bretagne. Miner. Deposita 8, 7-18

Dubessy, J., 1984. Simulation des équilibres chimiques dans le système COH. Conséquences méthodologiques pour les inclusions fluides. Br. Mineral. 107, 155168.

Dubessy, J., Poty, B., Ramboz, C., 1989. Advances in COHNS fluid geochemistry based on micro-Raman spectrometric analysis of fluid inclusions. Eur. J. Mineral. 517-534.

Essarraj, S., Boiron, M.C., Cathelineau, M., Fourcade, S., 2001. Multistage deformation of Auquartz veins (Laurieras, French Massif Central): evidence for late gold introduc-tion from microstructural, isotopic and fluid inclusion studies. Tectonophysics 336, 79-99.

Faleiros, F.M., Campanha, G.A.C., Bello, R.M.S., Fuzikawa, K., 2007. Fault-valve action and vein development during strike-slip faulting: an example from the Ribeira Shear Zone, southeastern Brazil. Tectonophysics 438, 1-32.

Gaboury, D., Daigneault, R., 2000. Flat vein formation in a transitional crustal setting by selfinduced fluid pressure equilibrium - an example from the Géant Dormant gold mine Canada. Ore Geol. Rev. 17, 155-178.

Gapais, D., Le Corre, C., 1980. Is the Hercynian belt of Brittany a major shear zone. Nature $288,574-576$.

Gloaguen, E., Branquet, Y., Boulvais, P., Moelo, Y., Chauvel, J.-J., Chiappero, P.-J., Marcoux, E., 2007. Palaeozoic oolitic ironstone of the French Armorican Massif, a chemical and structural trap for orogenic base metal-As-Sb-Au mineralization during Hercynian strike-slip deformation. Miner. Deposita 42, 399-422.

Gloaguen, E., Tourlière, B., Angel, J.M., 2016a. Revalorisation du potentiel minier français Méthodes prédictives appliquées à la province à antimoine du Massif ar-moricain. BRGM report. BRGM/RP-65534-FR $71 \mathrm{pp.}$

Gloaguen, E., Tourlière, B., Angel, J.M., 2016b. Revalorisation du potentiel minier français : le district antimonifère du Semnon (Ille-et-Vilaine, France). BRGM report. BRGM/RP66200-FR 71 pp. http://infoterre.brgm.fr/rapports/RP-66200-FR.pdf.

Goldfarb, R.J., Groves, D.I., Gardoll, S., 2001. Orogenic gold and geologic time; a global synthesis. Ore Geol. Rev. 18, 1-75.

Goldfarb, R.J., Baker, T., Dubé, B., Groves, D.I., Hart, C.J.R., Gosselin, P., 2005. Distribution, character, and genesis of gold deposits in metamorphic terranes. Econ. Geol. 100th Anniversary, 407-450.

Goldfarb, R.J., Groves, D.I., 2015. Orogenic gold: Common or evolving fluid and metal sources through time. Lithos 233, 2-26.

Grand'Homme, A., Janots, E., Seydoux-Guillaume, A.M., Guillaume, D., Bosse, V., Magnin, V., 2016. Partial resetting of the U-Th-Pb systems in experimentally altered monazite: Nanoscale evidence of incomplete replacement. Geology 44, 431-434.

Groves, D.I., Goldfarb, R.J., Gebre-Mariam, M., Hagemann, S.G., Robert, F., 1998. Orogenic gold deposits-a proposed classification in the context of their crustal distribution and relationship to other gold deposit types. Ore Geol. Rev. 13, 7-27.

Groves, D.I., Goldfarb, R.J., Robert, F., Hart, C.J.R., 2003. Gold deposits in metamorphic belts: overview of current understanding, outstanding problems, future research, and exploration significance. Econ. Geol. 98, 1-29.

Gumiaux, C., Brun, J.P., Gapais, D., 2004a. Strain removal within the Hercynian Shear Belt of Central Brittany (western France): methodology and tectonic implications. In: Alsop, G.I., Holdsworth, R.E., McCaffrey, K.J.W., Hand, M. (eds) Flow processes in faults and shear zones. Geol. Soc. Spec. Publ. 224, 287-305.

Gumiaux, C., Gapais, D., Brun, J.P., Chantraine, J., Ruffet, G., 2004b. Tectonic history of the Hercynian Armorican Shear belt (Brittany, France). Geodin. Acta 17, 289-307.

Gumiel, P., Arribas, A., 1987. Antimony deposits in the Iberian Peninsula. Econ. Geol. 82, $1453-1463$.

Harlov, D.E., Hetherington, C.J., 2010. Partial high-grade alteration of monazite using alkalibearing fluids: Experiment and nature. Am. Mineral. 95, 1105-1108.

Harlov, D.E., Wirth, R., Förster, H.J., 2005. An experimental study of dissolution-reprecipitation in fluorapatite: fluid infiltration and the formation of monazite. Contrib. Mineral. Petrol. 150, 268-286.

Harlov, D.E., Wirth, R., Hetherington, C.J., 2007. The relative stability of monazite and huttonite at 300-900 C and 200-1000 MPa: metasomatism and the propagation of metastable mineral phases. Am. Mineral. 92, 1652-1664.

Harlov, D.E., Wirth, R., Hetherington, C.J., 2011. Fluid-mediated partial alteration in monazite: the role of coupled dissolution-reprecipitation in element redistribution and mass transfer. Contrib. Mineral. Petrol. 162, 329-348.

Henderson, I.H.C., MacCaig, A.M., 1996. Fluid pressure and salinity variations in shear zonerelated veins, central Pyrenees, France: implications for the fault-valve model. Tectonophysics 262, 321-348.

Herrouin, Y., Rabu, D., Chantraine, J., Chauvel, J.J., Etienne, H., 1990. Geological map of France (1/50000), notice of the Châteaubriand sheet (389). BRGM, Orléans, France, pp. 53.

Kolb, J., Rogers, A., Meyer, F.M., Vennemann, T.W., 2004. Development of fluid conduits in the auriferous shear zones of the Hutti Gold Mine, India: evidence for spatially and temporally heterogeneous fluid flow. Tectonophysics 378, 65-84.

Kretschmar, U., Scott, S.D., 1976. Phase relations involving arsenopyrite in the system FeAs-S and their application. Can. Miner. 14, 364-386.

Krupp, R.E., 1988. Solubility of stibnite in hydrogen sulfide solutions, speciation, and equilibrium constants, from 25 to $350^{\circ} \mathrm{C}$. Geochim. Cosmochim. Acta 52, 3005-3015.

Le Corre, C., 1969. Sur une paragenèse à chloritoïde dans les schistes de l'Ordovicien moyen des synclinaux du Sud de Rennes (Massif Armoricain). Bull. Soc. Géol. Minéral. C 3344.

Le Corre, C., 1975. Analyse comparee de la cristallinite des micas dans le Brioverien et le Paleozoique centre-armoricains; zoneographie et structure d'un domaine epizonal. B. Soc. Geol. Fr. 7, 547-553.

Ludwig, K.R., 2012. User's Manual for Isoplot 3.75. A geochronological toolkit for Microsoft Excel. Berkeley Geochronological Cent, 1-75.

Marcoux, E., 1987. Isotopes du plomb et paragenèses métalliques, traceurs de l'histoire des gîtes minéraux. Doc BRGM 117, Orléans.

Marcoux, E., Serment, R., Allon, A., 1984. Les gîtes d'antimoine de Vendée (Massif Armoricain, France). Historique des recherches et synthèse métallogénique. Chron. Rech. Min. 476, 3-30.

Marot, A., 1984. Etude géologique de la concession du Semnon. BRGM report. AGI/OST/ 84.02 MA 56 pp.

Matte, P., 1986. La chaîne Varisque parmi les chaînes Paléozoïques péri atlantiques, modèle d'évolution et position des grands blocs continentaux au Permo-Carbonifère. B. Soc. Geol. Fr. 2, 9-24.

McCuaig, T.C., Kerrich, R., 1998. P-T-t-deformation-fluid characteristics of lode gold deposits: evidence from alteration systematics. Ore Geol. Rev. 12, 381-454.

McDowell, F.W., McIntosh, W.C., Farley, K.A., 2005. A precise 40Ar-39Ar reference age for the Durango apatite (U-Th)/He and fission-track dating standard. Chem. Geol. 214, 249263.

Micklethwaite, S., 2008. Optimally oriented 'fault valve' thrusts: Evidence for aftershockrelated fluid pressure pulses? Geochem. Geophys. Geosyst. 9, Q04012. http://dx.doi. org/10.1029/2007GC001916.

Neiva, A.M.R., Andras, P., Ramos, J.M.F., 2008. Antimony quartz and antimony-gold quartz veins from northern Portugal. Ore Geol. Rev. 34, 533-546.

Němec, M., Zachariáš, J., 2017. The Krásná Hora, Milešov, and Příčovy Sb-Au ore de-posits, Bohemian Massif: mineralogy, fluid inclusions, and stable isotope constraints on the deposit formation. Miner. Deposita. http://dx.doi.org/10.1007/s0012.

Nguyen, P.T., Cox, S.F., Harris, L.B., Powell, C.M., 1998. Fault-valve behaviour in opti-mally oriented shear zones: an example at the Revenge gold mine, Kambalda, Western Australia. J. Struct. Geol. 20, 1625-1640.

Obolensky, A.A., Gushchina, L.V., Borisenko, A.S., Borovikov, A.A., Nevol'ko, P.A., 2009. Computer thermodynamic modeling of the transport and deposition of $\mathrm{Sb}$ and Au during the formation of Au-Sb deposits. Russ. Geol. Geophys. 50, 950-965.

Ortega, L., Vindel, E., 1995. Evolution of ore-forming fluids associated with late Hercynian antimony deposits in central/western Spain: case study of Mari Rosa and El Juncalón. Eur. J. Mineral. 7, 655-673.

Ortega, L., Oyarzun, R., Gallego, M., 1996. The Mari Rosa late Hercynian Sb-Au deposit, western Spain. Miner. Deposita 31, 172-187.

Paton, C., Woodhead, J.D., Hellstrom, J.C., Hergt, J.M., Greig, A., Maas, R., 2010. Improved laser ablation U-Pb zircon geochronology through robust downhole frac-tionation correction. Geochem. Geophys. Geosyst. 11 Q0AA06.

Paquette, J.L., Piro, J.L., Devidal, J.L., Bosse, V., Didier, A., Sanac, S., Abdelnour, Y., 2014. Sensitivity enhancement in LA-ICP-MS by N2 addition to carrier gas: Application to radiometric dating of U-Th-bearing minerals. Agilent ICP-MS J. 58, $4-5$.

Paquette, J.L., Ballèvre, M., Peucat, J.J., Cornen, G., 2017. From opening to subduction of an oceanic domain constrained by LA-ICP-MS U-Pb zircon dating (Variscan belt, Southern Armorican Massif, France). Lithos 294-295, 418-437.

Périchaud, J.J., 1980. L'antimoine, ses minérais et ses gisements. Synthèse gîtologique sur les gisements du Massif Central français. Ch. Rech. Min. 456, 5-64.

Pochon, A., Gapais, D., Gloaguen, E., Gumiaux, C., Branquet, Y., Cagnard, F., Martelet, G., 2016a. Antimony deposits in the Variscan Armorican belt, a link with mafic intrusives? Terra Nova 28, 138-145.

Pochon, A., Poujol, M., Gloaguen, E., Branquet, Y., Cagnard, F., Gumiaux, C., Gapais, D., 2016b. U-Pb LA-ICP-MS dating of apatite in mafic rocks: Evidence for a major magmatic event at the Devonian-Carboniferous boundary in the Armorican Massif (France). Am. Mineral. 101, 2430-2442.

Pochon, A., Beaudoin, G., Branquet, Y., Boulvais, P., Gloaguen, E., Gapais, D., 2017. Metal mobility during hydrothermal breakdown of Fe-Ti oxides: insights from Sb-Au mineralizing event (Variscan Armorican Massif, France). Ore Geol. Rev. 91, 66-99.

Ramsay, J.G., 1980. The crack-seal mechanism of rock deformation. Nature 284, 135139

Ridley, J.R., Diamond, L.W., 2000. Fluid chemistry of orogenic lode gold deposits and implications for genetic models. Rev. Econ. Geol. 13, 141-162. 
Robert, F., Brown, A.C., 1986. Archean gold-bearing quartz veins at the Sigma Mine, Abitibi greenstone belt, Quebec, I. Geologic relations and formation of the vein system. Econ. Geol. 81, 578-592.

Robert, F., Boullier, A.M., Firdaous, K., 1995. Gold-quartz veins in metamorphic terranes and their bearing on the role of fluids in faulting. J. Geophys. Res. 100, 12841-12859.

Romer, R.L., Kroner, U., 2018. Paleoizoic gold in the Appalachians and Variscides. Ore Geol. Rev. 92, 475-505.

Ruffet, G., Féraud, G., Amouric, M., 1991. Comparison of 40Ar/39Ar conventional and laser dating of biotites from the North Tregor batholith. Geochim. Cosmochim. Acta 55, 16751688 .

Ruffet, G., Féraud, G., Ballèvre, M., Kiénast, J.R., 1995. Plateau ages and excess argon in phengites: A 40Ar-39Ar laser probe study of Alpine micas (Sesia Zone, Western Alps, northern Italy). Chem. Geol. (Isotopic Geoscience Section) 121, 327-343.

Seydoux-Guillaume, A.M., Montel, J.M., Bingen, B., Bosse, V., De Parseval, P., Paquette, J.L., Janots, E., Wirth, R., 2012. Low-temperature alteration of monazite: Fluid mediated coupled dissolution-precipitation, irradiation damage, and disturbance of the U-Pb and Th-Pb chronometers. Chem. Geol. 330, 140-158.

Schoene, B., Bowring, S.A., 2006. U-Pb systematics of the McClure Mountain syenite: thermochronological constraints on the age of the ${ }^{40} \mathrm{Ar} /{ }^{39} \mathrm{Ar}$ standard MMhb. Contrib. Mineral. Petrol. 151, 615-630.

Sharp, Z.D., Essene, E.J., Kelly, W.C., 1985. A re-examination of the arsenopyrite geothermometer: pressure considerations and applications to natural assemblages. Can. Miner. 23, 517-534.

Shikina, N.D., Zotov, A.V., 1991. Thermodynamics parameters of $\mathrm{Sb}(\mathrm{OH}) 03(\mathrm{sol})$ up to $723.15 \mathrm{~K}$ and 1000 bar. Geochem. Int. 28, 97-103.

Sibson, R.H., 1985. A note on fault reactivation. J. Struct. Geol. 7, 751-754.

Sibson, R.H., 1987. Earthquake rupturing as a hydrothermal mineralizing agent. Geology 15, 701-704.

Sibson, R.H., 2001. Seismogenic framework for hydrothermal transport and ore deposi-tion. Rev. Econ. Geol. 14, 25-50.

Sibson, R.H., Robert, F., Poulsen, K.H., 1988. High-angle reverse faults, fluid pressure cycling, and mesothermal gold-quartz deposits. Geology 16, 551-555.

Spycher, N.F., Reed, M.H., 1989. As(III) and Sb(III) sulfide complexes: An evaluation of stoichiometry and stability from existing experimental data. Geochim. Cosmochim. Acta $53,2185-2194$.
Stacey, J.S., Kramers, J.D., 1975. Approximation of terrestrial lead isotope evolution by a twostage model. Earth Planet. Sci. Lett. 26, 207-221.

Tartèse, R., Poujol, M., Ruffet, G., Boulvais, P., Yamato, P., Košler, J., 2011. New U-Pb zircon and 40Ar/39Ar muscovite age constraints on the emplacement of the Lizio syntectonic granite (Armorican Massif, France). C. R. Geosci. 343, 443-453.

Thiéry, R., Van Den Kerkhof, A.M., Dubessy, J., 1994. vX properties of CH 4-CO 2 and CO 2 $\mathrm{N} 2$ fluid inclusions: Modelling for T $<31 \mathrm{C}$ and $\mathrm{P}<400$ bars. Eur. J. Mineral. 6 (6), 753-771.

Thomson, S.N., Gehrels, G.E., Ruiz, J., Buchwaldt, R., 2012. Routine low-damage apatite U-Pb dating using laser ablation-multicollector-ICPMS. Geochem. Geophys. Geosyst. 13 Q0AA21.

Tremblay, A., Ruffet, G., Bédard, J.H., 2011. Obduction of Tethyan-type ophiolites-A casestudy from the Thetford-Mines ophiolitic Complex, Quebec Appalachians, Canada. Lithos 125, 10-26.

Van Achterbergh, E., Ryan, C.G., Jackson, S.E., Griffin, W.L., 2001. Data reduction soft-ware for LA-ICP-MS: appendix. In: Sylvester, P.J. (Ed.), Laser Ablation-ICP-mass Spectrometry in the Earth Sciences: Principles and Applications. Mineralogical Association of Canada, Ottawa, pp. 239-243.

Vernhet, Y., Plaine, J., Trautmann, F., Pivette, B., 2009. Geological map of France (1/ 50000), notice of the Cossé-le-Vivien sheet (355). BRGM, Orléans, France, pp. 222.

Vigneresse, J.L., Tikoff, B., Amélio, L., 1999. Modification of the regional stress field by magma intrusion and formation of tabular granitic plutons. Tectonophysics 302, 203-224.

Wagner, T., Cook, N.J., 2000. Late-Variscan antimony mineralization in the Rheinisches Schiefergebirge, NW: evidence for stibnite precipitation by drastic cooling of high temperature fluid systems. Miner. Deposita 35, 206-222.

Whitney, D.L., Evans, B.W., 2010. Abbreviations for names of rock-forming minerals. Am. Mineral. 95, 185-187.

Williams-Jones, A.E., Normand, C., 1997. Controls of mineral parageneses in the System FeSb-S-O. Econ. Geol. 92, 308-324.

Wood, S.A., Crerar, D.A., Borcsik, M.P., 1987. Solubility of the assemblage pyrite-pyrrhotite-magnetite-galena-gold-stibnite-bismuthinite-argentite-molybdeniitne $\mathrm{H} 2 \mathrm{O}-\mathrm{NaC1}$ $\mathrm{CO} 2$ solutions from 200 to $350^{\circ} \mathrm{C}$. Econ. Geol. 82, 1864-1887.

Zack, T., Stockli, D.F., Luvizotto, G.L., Barth, M.G., Belousova, H., Wolfe, M.R., Hinton, R.W., 2011. In situ U-Pb rutile dating by LA-ICP-MS: 208Pb correction and prospects for geological applications. Contrib. Miner. Petrol. 162, 515-530. 